\title{
INSTRUMENTOS DE POLÍTICA AMBIENTAL PARA REDUÇÃO DA GERAÇÃO DOS RESÍDUOS SÓLIDOS URBANOS: A PERCEPÇÃO DE ESPECIALISTAS NO MUNICÍPIO DE GOIÂNIA - GO
}

Will Sandes de Melo

Francis Lee Ribeiro

Cleidinaldo de Jesus Barbosa

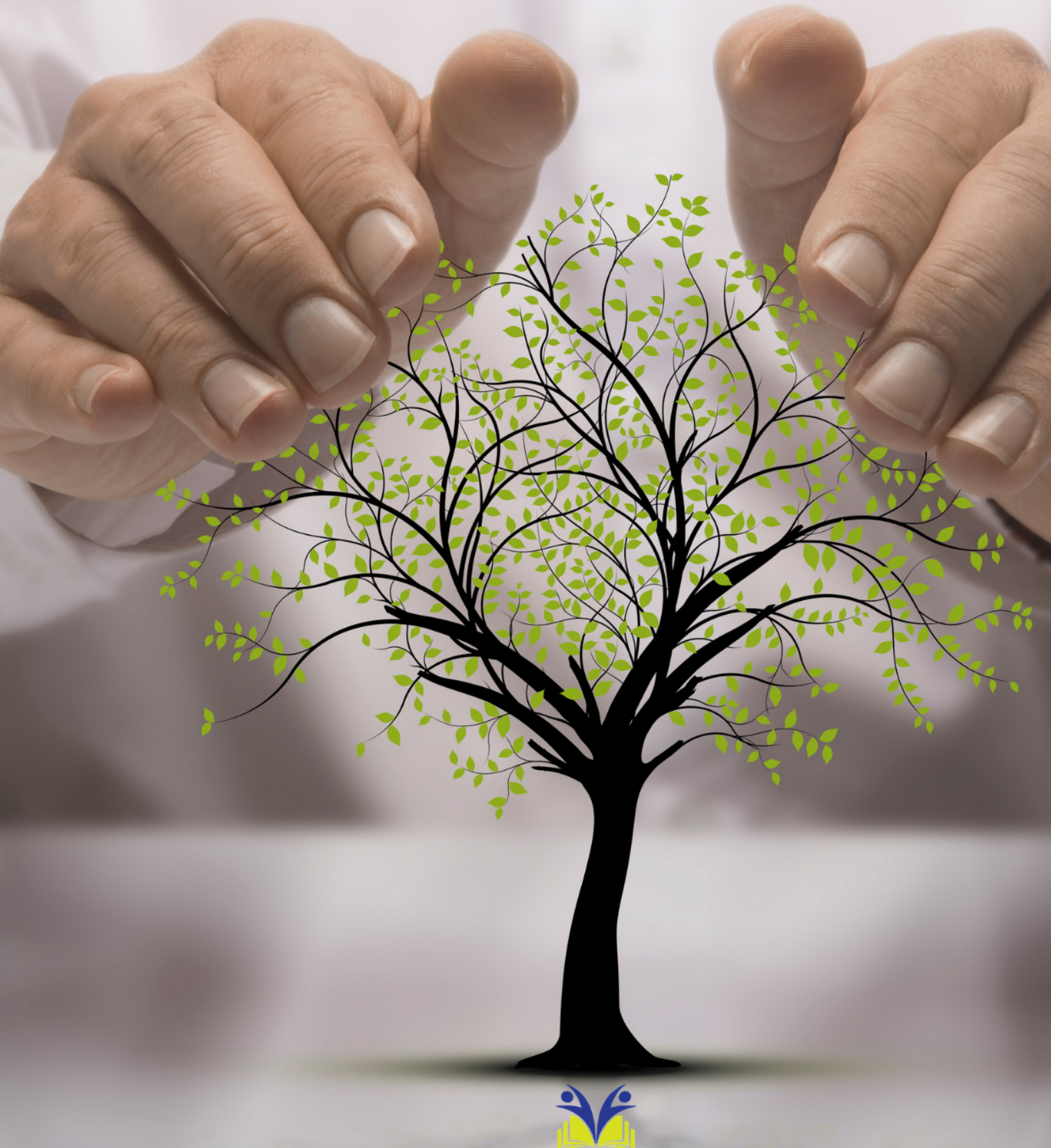


Will Sandes de Melo

Francis Lee Ribeiro

Cleidinaldo de Jesus Barbosa

INSTRUMENTOS DE POLÍTICA AMBIENTAL PARA REDUÇÃO DA GERAÇÃO DOS RESÍDUOS SÓLIDOS URBANOS: A PERCEPÇÃO DE ESPECIALISTAS NO MUNICÍPIO DE GOIÂNIA - GO

$1^{\text {a }}$ ed. 
$1^{\mathrm{a}} \mathrm{ed}$

\section{Dados Internacionais de Catalogação na Publicação (CIP)}

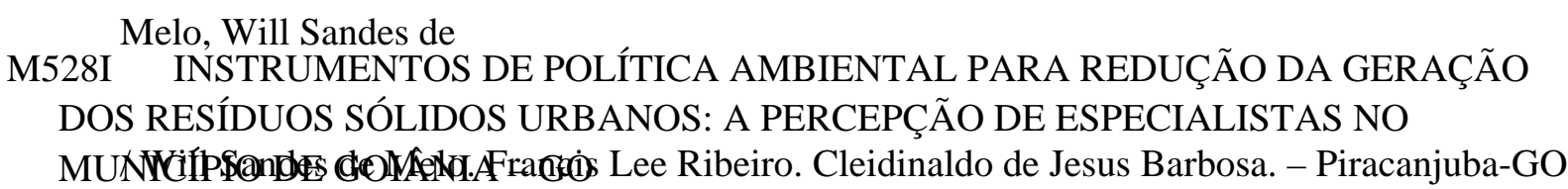

Editora Conhecimento Livre, 2021

88 f.: il

DOI: $10.37423 / 2021$. edcl 263

ISBN: 978-65-89955-05-4

Modo de acesso: World Wide Web

Incluir Bibliografia

1. redução-da-geração-de-resíduos 2. políticas-para-gestão-de-resíduos 3. instrumentos-econômicospara-gestão-dos-resíduos I. Melo, Will Sandes de II. Ribeiro, Francis Lee III. Barbosa, Cleidinaldo de Jesus IV. Título

https://doi.org/10.37423/2021.edc1263

O conteúdo dos artigos e sua correção ortográfica são de responsabilidade exclusiva dos seus respectivos autores. 


\section{EDITORA CONHECIMENTO LIVRE}

\section{Corpo Editorial}

Dr. João Luís Ribeiro Ulhôa

Dra. Eyde Cristianne Saraiva-Bonatto

MSc. Anderson Reis de Sousa

$\underline{\text { MSc. Frederico Celestino Barbosa }}$

MSc. Carlos Eduardo de Oliveira Gontijo

MSc. Plínio Ferreira Pires

Editora Conhecimento Livre

Piracanjuba-GO 

GOIÂNIA - GO

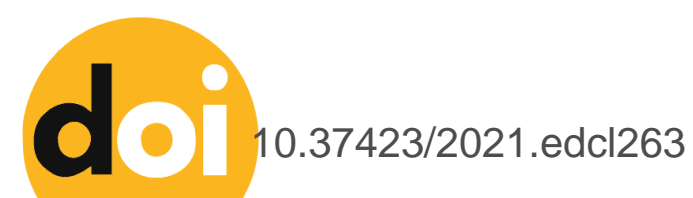

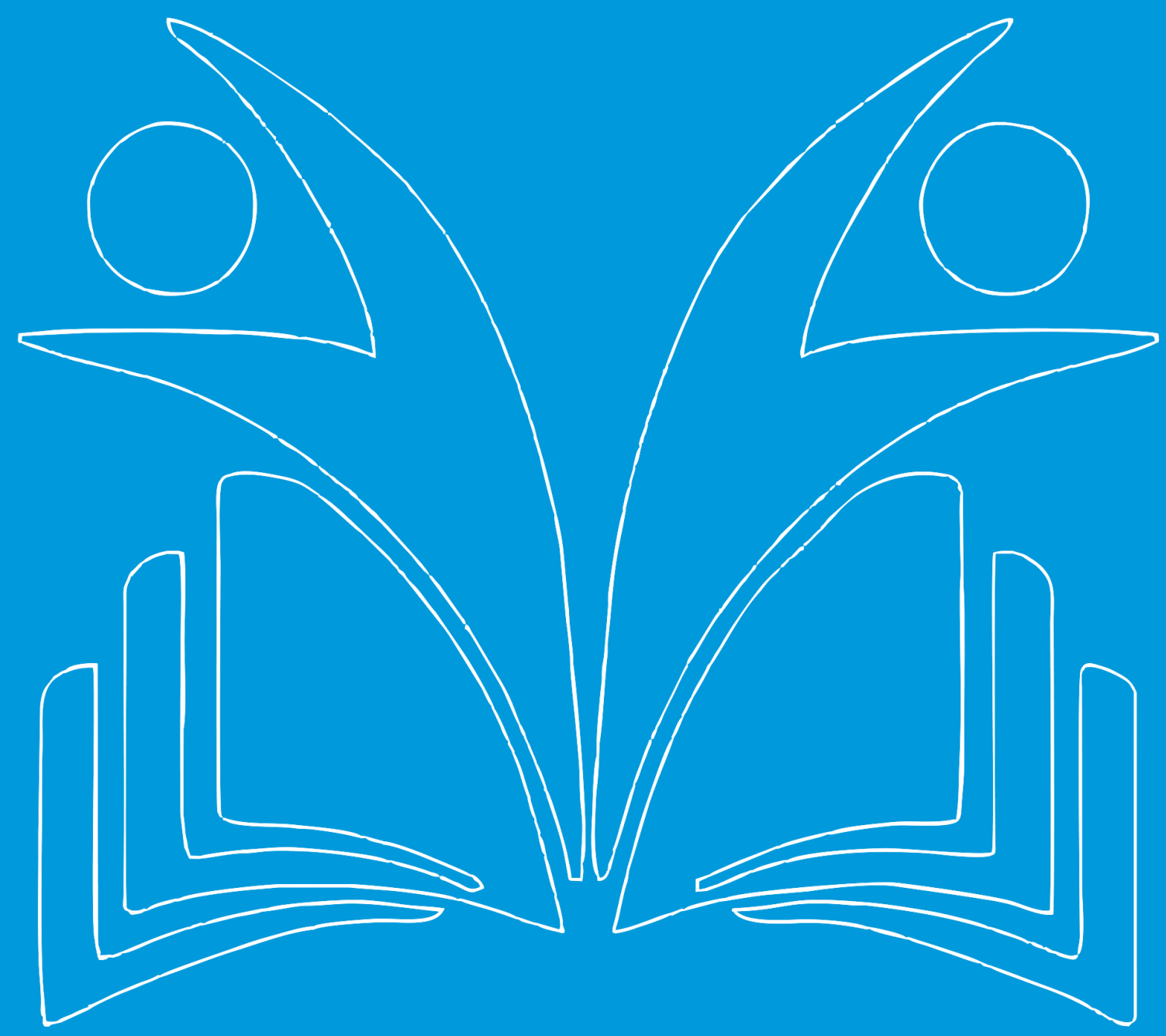




\section{Sumário}

1. INTRODUÇÃO

1.1. O CONCEITO DE REDUÇÃO DA GERAÇÃO DE RESÍDUOS 6

1.2. INSTRUMENTOS PARA CONTROLE DA POLUIÇÃO …..........................................................................................

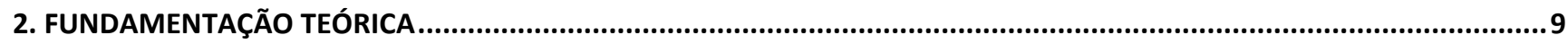

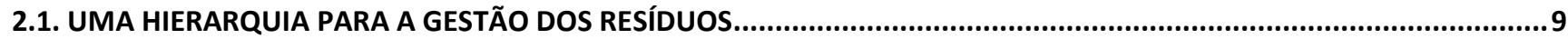

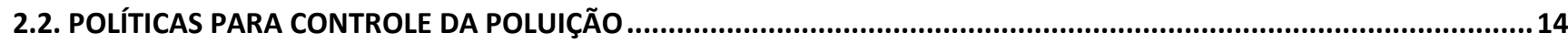

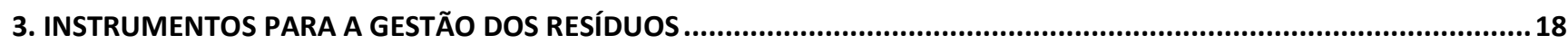

3.1. INSTRUMENTOS DE COMANDO E CONTROLE................................................................................................

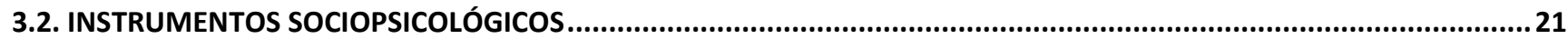

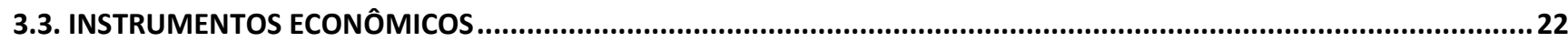

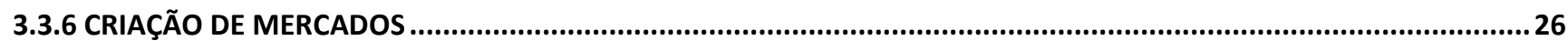

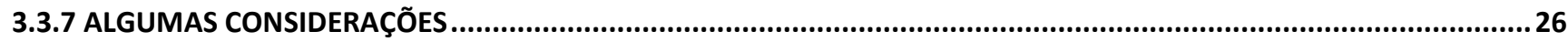

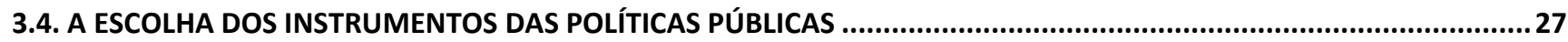

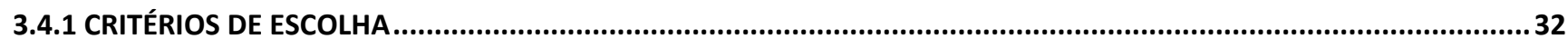

4. A HIERARQUIA PARA GESTÃO DOS RESÍDUOS E OS INSTRUMENTOS ECONÔMICOS EM DIFERENTES ESFERAS DE

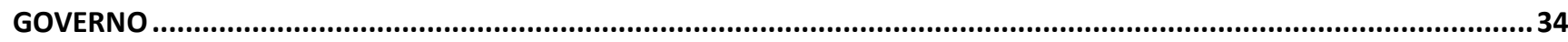

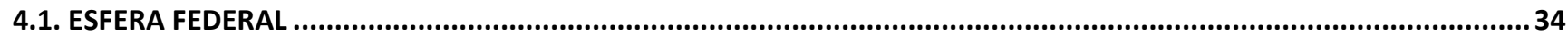

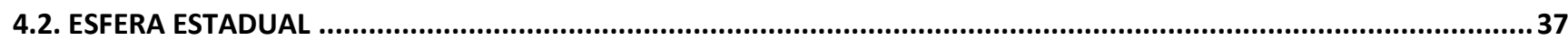

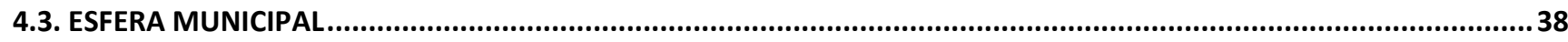

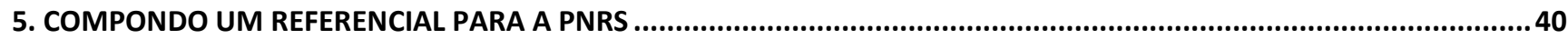

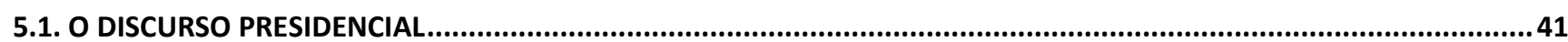

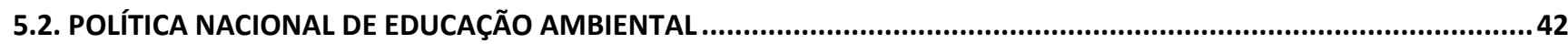

5.3. COMITÊ INTERMINISTERIAL DA INCLUSÃO SOCIAL DE CATADORES DE LIXO …...................................................43

5.4. PLANO DE AÇÃO PARA PRODUÇÃo E CONSUMO SUSTENTÁVEIS.......................................................................44

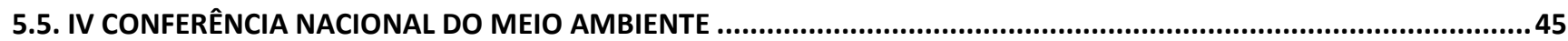

5.6. PLANO DE RESÍDUOS E MINUTA DA POLÍTICA MUNICIPAL DE GESTÃO INTEGRADA DE RESÍDUOS DE GOIÂNIA .....47 


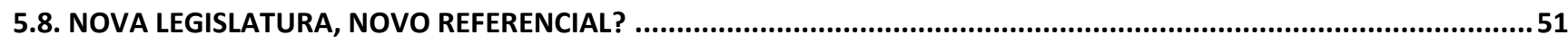

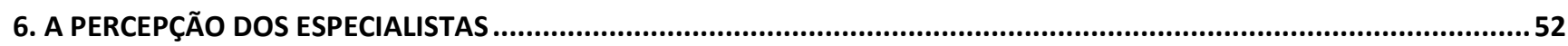

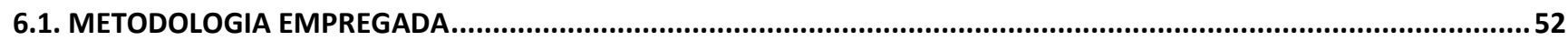

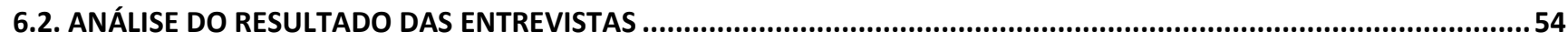

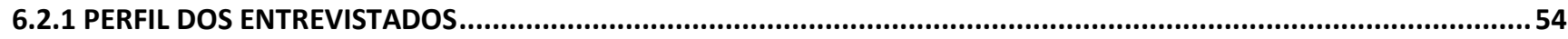

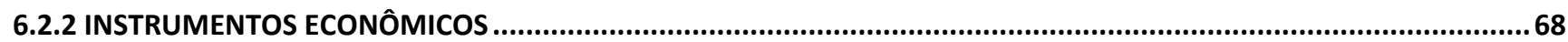

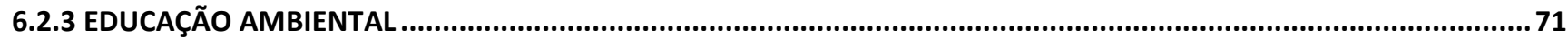

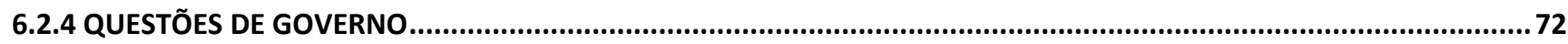

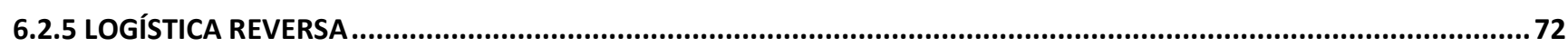

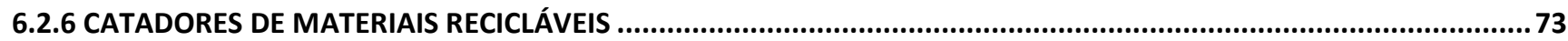

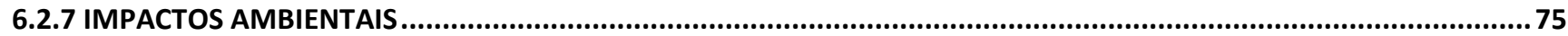

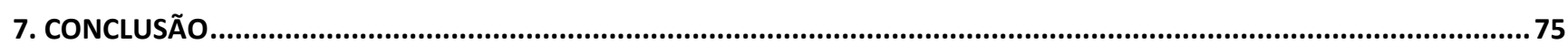

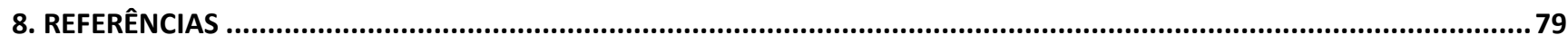

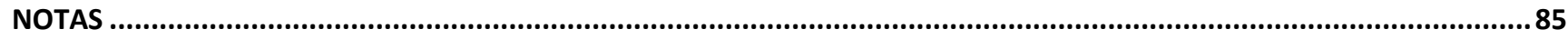




\section{INTRODUÇÃO}

Presume-se que a implementação satisfatória de uma política requer necessariamente a assimilação de seus princípios e objetivos, bem como o domínio dos instrumentos disponíveis para atingi-los.

Compreender as diretrizes da Política Nacional de Resíduos Sólidos - PNRS talvez demande menos esforço do que estabelecer os melhores caminhos para alcançá-las. Podemos delimitar o objetivo central da Lei ao interpretar a hierarquia para a gestão dos resíduos, art. 9 da PNRS, a qual nos remete quase que imediatamente à redução da dependência de aterros sanitários, seja por meio da reciclagem, seja por meio da não geração de resíduos.

Reduzir a geração é o conceito mais atual em termos de prioridades para a gestão dos resíduos, tratase de um avanço conceitual em relação ao protagonismo da reciclagem como solução para a destinação deles. De toda sorte, independente da ordem de preferência entre a reciclagem ou o reúso, por exemplo, há um claro consenso - no meio acadêmico e nas políticas mundo afora - de que a disposição dos resíduos em aterros deve ser sempre a última solução a se adotar, mesmo que os aterros estejam devidamente adequados a este fim.

Há muitos instrumentos, ou meios de fomentar a redução da disposição de resíduos sólidos urbanos. Obviamente, alcançar esse objetivo em nível nacional não é uma tarefa fácil, pois existem enormes disparidades entre os órgãos responsáveis pela implementação da política no âmbito local. Além das diferenças em termos culturais, também há disparidades em termos de recursos humanos, financeiros e até mesmo da inexistência de instituições encarregadas das políticas de resíduos.

A primeira parte desse trabalho discorre sobre os conceitos subjacentes à redução da geração dos resíduos, entendido aqui como o cerne da PNRS. Depois são apresentados os principais instrumentos elegíveis à consecução desse objetivo, bem como as teorias que os sustentam. Em seguida averíguase a ênfase à redução da geração dos resíduos no arcabouço legal e de planejamento da gestão de resíduos nos âmbitos federal, do Estado de Goiás e do Município de Goiânia.

A segunda parte investiga a literatura a respeito do momento de tomada de decisão em relação aos instrumentos de políticas públicas. Devidamente amparados conceitualmente a respeito do objetivo da Lei, dos instrumentos para alcance desses objetivos, bem como do contexto de escolha desses instrumentos, procurou-se verificar se há alguma predileção em relação a esses e porque isso ocorre. 
Para tanto, foram analisados documentos oficiais que exprimem ideias e conceitos em torno da implementação da Política Nacional de Resíduos Sólidos, as quais foram confrontadas com as percepções de especialistas que atuam ou atuaram no âmbito municipal.

\subsection{O CONCEITO DE REDUÇÃO DA GERAÇÃO DE RESÍDUOS}

A disposição de resíduos em aterros é um tipo de tratamento amplamente adotado em todo o Brasil, por ser considerado de baixo custo em relação a outras tecnologias de tratamento, tais como a incineração. Porém, as formas convencionais de contabilização dos custos operacionais do aterramento não consideram os custos sociais decorrentes de impactos ambientais como a contaminação por chorume e a emissão de gases de efeito estufa, externalidades negativas, ligadas especialmente à utilização de aterros inadequados - os lixões. (GOUVEIA, 2012; MONTEIRO et al., 2001; TAYLOR, 2000).

Reduzir a quantidade de resíduos gerados pelas atividades humanas é uma estratégia para minimizar os custos de gerenciamento, bem como os impactos ambientais de tratamentos como a disposição em aterros. Não por acaso, a redução da geração é um dos objetivos da Política Nacional de Resíduos Sólidos. (GOUVEIA, 2012; AGUIAR; EL-DEIR; BEZERRA, 2017; MAIELLO; BRITTO; VALLE, 2018).

Para alcançar a gestão sustentável dos resíduos é fundamental prevenir a sua geração na fonte. Uma vez que são gerados, deve-se priorizar o reúso, a reciclagem e o aproveitamento energético, dessa forma, apenas rejeitos deveriam ser encaminhados para aterros sanitários. (PHILLIPS et al., 2002).

Instituída em 2010, após 20 anos de discussões, a PNRS acompanha a evolução das políticas no exterior e impõe uma hierarquia para a gestão e gerenciamento, a qual prevê a seguinte ordem de prioridade: não geração, redução, reutilização, reciclagem, tratamento dos resíduos sólidos e disposição final ambientalmente adequada dos rejeitos. (BRASIL, 2010; DEMAJOROVIC, 1995; GODECKE et al., 2012; FGV PROJETOS, 2015; HEBER; SILVA, 2014; MELLO et al., 2018).

Na literatura estrangeira encontram-se referências aos termos minimização, redução e prevenção da geração de resíduos, que de toda sorte dizem respeito a uma mesma gama de ações. Mais adiante serão discutidas as definições dessas expressões. De maneira geral, a prevenção englobaria a não geração e o reúso. Já a minimização comporta a prevenção e os esforços para reduzir o total de materiais já descartados, evitando sua disposição em aterros por meio de processos como a reciclagem, a compostagem e o aproveitamento energético. (CORVELLEC, 2016; TAYLOR, 2000). 
Mas quais seriam os meios para promover a redução da geração dos resíduos sólidos urbanos? A própria legislação correlata traz algumas indicações nesse sentido. Outra fonte de respostas para essa pergunta é a literatura especializada que revela a possibilidade de utilização de uma gama de instrumentos já consagrados nos debates em torno das políticas ambientais.

Configura-se assim o primeiro grande objetivo deste trabalho que é analisar os instrumentos de políticas ambientais aplicáveis à redução da geração de resíduos. Para tanto, será apresentada uma revisão da literatura sobre o tema, bem como uma breve análise da legislação nas esferas federal, estadual e municipal, tendo como foco o Estado de Goiás e o Município de Goiânia.

A fim de delimitar o escopo da pesquisa, as políticas para redução da geração dos resíduos sólidos urbanos são tidas como parte dos esforços para o controle da poluição, campo de estudos para o qual as teorias econômicas oferecem valiosas contribuições. Dessa forma, parte relevante da revisão de literatura é dedicada aos instrumentos econômicos aplicáveis à gestão dos resíduos, o que fornece os subsídios necessários para consecução do segundo objetivo do trabalho: apontar se há uma preferência por determinados tipos de instrumentos, bem como avaliar o que explicaria essa preferência.

\subsection{INSTRUMENTOS PARA CONTROLE DA POLUIÇÃO}

A teoria econômica neoclássica compreende a poluição ambiental resultante das atividades econômicas como um externalidade negativa da produção. A externalidade negativa ocorre quando uma determinada atividade causa perda de bem-estar a algum indivíduo ou comunidade, por exemplo. Uma forma de controlar a poluição seria fazer com que os agentes poluidores de alguma forma recompensassem os indivíduos lesados com a perda de bem-estar. Em outras palavras, seria possível reduzir a poluição forçando os agentes poluidores a somarem os custos das externalidades negativas de suas atividades aos seus custos de produção. (ALMEIDA, 1998; BERNARDO; NOGUEIRA, 2016; SEROA DA MOTTA; SAYAGO, 1998).

Porém, em se tratando de dano ao meio ambiente, essa compensação torna-se complexa em função dos efeitos difusos da degradação ambiental e da dificuldade de se valorar a perda do bem-estar dos indivíduos. Tendo em vista essas características, passa-se a considerar as intervenções governamentais como fundamentais para conter o processo de degradação do meio ambiente. Duas vias consagradas para consecução desse objetivo são a regulamentação - comando e controle - e os instrumentos econômicos. (ALMEIDA, 1998). 
As primeiras legislações ambientais modernas datam da década de 1970 e - nos países anglo-saxões - caracterizavam-se por uma abordagem comando e controle, considerada intervencionista, basicamente por meio do estabelecimento de padrões de emissão (comando) e penalidades para o descumprimento desses padrões (controle). (GUNNINGHAM, 2009).

Nos anos 1980 o caráter intervencionista da abordagem comando e controle foi duramente criticado, muito em função do contexto político neoliberal prevalente em nações como os Estados Unidos e o Reino Unido. Surgem assim correntes em defesa do uso dos instrumentos econômicos que trariam diversas vantagens em relação às tradicionais regulações comando e controle, por meio da aplicação de instrumentos de mercado, como taxas, subsídios e alocação de direitos de propriedade para o comércio de licenças e permissões. (GUNNINGHAM, 2009).

Todavia, apesar das pretensas vantagens teóricas, a aplicação de instrumentos econômicos permanece à sombra das regulamentações. Na política ambiental brasileira, parece prevalecer o uso de comando e controle, cenário que não difere do contexto internacional. Porém, garantir a efetividade das políticas para controle da poluição exige bem mais do que a mera regulação, o recomendável é que se alie o uso de instrumentos de comando e controle aos instrumentos econômicos e de educação ambiental. (ALMEIDA, 1998; BARROS et al., 2012; GUNNINGHAM, 2009).

A preferência pelo uso dos instrumentos de comando e controle no Brasil pode ser explicada por diversos fatores, desde a participação incipiente de economistas nas discussões das políticas ambientais até o caráter imediatista das políticas adotadas que apostam na facilidade de criação de regulações como solução para os problemas ambientais, muitas vezes sem considerar o custo benéfico da implementação das mesmas. Também é possível citar a familiaridade da população e dos agentes públicos com esse tipo de instrumento. (ALMEIDA, 1998; BARROS et al., 2012).

Supõe-se que a preferência dos especialistas e agentes públicos seja guiada por aspectos basilares das políticas ambientais como efetividade, eficiência e aceitação política, devendo-se ponderar ainda a própria limitação do entendimento que estes atores possuem do funcionamento dessas políticas. (GUNNINGHAM, 2009).

Há, porém, no campo das políticas públicas, uma corrente teórica que aponta para a percepção dos agentes públicos como fator preponderante no momento de escolha dos instrumentos para implementação das políticas. Dentro dessa perspectiva, fazer escolhas complexas depende muito menos de critérios racionais do que de crenças e percepções previamente concebidas. É nessa base 
teórica que a presente pesquisa busca embasamento a fim de demonstrar a importância do referencial cognitivo como fator determinante do processo de escolhas dos instrumentos de gestão de resíduos. A presente pesquisa visa responder às seguintes questões:

a) Quais os principais instrumentos das políticas ambientais capazes de promover a redução da geração dos resíduos?

b) Há uma preferência por determinados instrumentos? O que explica essa preferência?

\section{Objetivo Geral}

Determinar se existe uma preferência em termos de instrumentos de políticas para redução da geração de resíduos sólidos urbanos no âmbito do município de Goiânia.

\section{Objetivos específicos}

a) Identificar na literatura especializada, os principais instrumentos de políticas ambientais para redução da geração de resíduos sólidos urbanos;

b) Revelar a percepção de gestores, técnicos e especialistas atuantes no âmbito do Município de Goiânia a respeito da implementação da PNRS e da aplicação de seus instrumentos;

c) Explicar o que pode determinar a preferência por determinados instrumentos de política de gestão de resíduos no âmbito municipal.

\section{Resultados Esperados}

Almeja-se obter uma explicação para a preferência de determinados instrumentos em detrimento de outros no âmbito das políticas públicas para gestão de resíduos. Espera-se assim fornecer subsídios que contribuam para o aperfeiçoamento do processo de implementação da PNRS.

\section{FUNDAMENTAÇÃO TEÓRICA}

\subsection{UMA HIERARQUIA PARA A GESTÃO DOS RESÍDUOS}

A maioria das regulamentações para gestão dos resíduos data de meados do século XIX no continente europeu. Naquela altura prevalecia um viés de saúde pública na essência dessas normas, cuja preocupação central era a remoção dos resíduos das grandes cidades. A partir da década de 1970 o viés ambiental ganhou relevância, o que trouxe à tona a necessidade de se priorizar a reciclagem e a redução da geração dos resíduos. Nesse contexto, surgiram as primeiras publicações em torno da 
hierarquia para a gestão dos resíduos, princípio que foi incorporado pelas legislações de muitos países europeus durante a década de 1980. (DEMAJOROVIC, 1995; LUDWIG; HELLWEG; STUCKI, 2003).

Um dos marcos para a prevenção e redução da geração dos resíduos foi a diretriz (75/442/EEC) do conselho da então Comunidade Europeia datada de 1975, a qual serviu de base para a primeira estratégia dela para a gestão dos resíduos (SEC (89) 934), editada em 1989, documento que estabelece a hierarquia da gestão dos resíduos com a máxima prioridade para a não geração. Esse princípio foi incorporado à legislação europeia em 2008 por meio da Diretriz 2008/98/EC que exigia a elaboração de planos nacionais de prevenção da geração de resíduos. (BARTL, 2014; GENTIL; GALLO; CHRISTENSEN, 2011; SALHOFER et al., 2008).

Conforme Taylor (2000), durante grande parte do século 20 a gestão dos resíduos sólidos urbanos nos Estados Unidos resumia-se à coleta e disposição em aterros. Já nas décadas de 1980 e 1990, a sustentabilidade na gestão ganhou força, com ênfase inicial na reciclagem e posteriormente na redução da geração. Para o autor, essa mudança foi impulsionada por fatores como o aumento da geração de resíduos; redução de áreas disponíveis para a disposição de resíduos; crescente conscientização dos danos ambientais associados à disposição; e aumento dos custos para disposição adequada.

Já no Brasil, o princípio da redução da geração dos resíduos foi evidenciado em nível nacional somente após a edição da Lei 12.305, a PNRS. Alinhada ao contexto internacional, essa Lei inclui entre os seus objetivos uma hierarquia para a gestão dos resíduos $^{1}$, a qual fixa a seguinte ordem: não geração, a redução, a reutilização, a reciclagem e tratamento dos resíduos, bem como a disposição final dos rejeitos. A incorporação da hierarquia reitera a preocupação com a disposição dos resíduos em aterros, ao sinalizar que esta opção deve ser a última preconizada, devendo os aterros serem destinos apenas de rejeitos. (GODECKE et al., 2012; HEBER; SILVA, 2014; OLIVEIRA; GALVÃO JUNIOR, 2016; SIQUEIRA; ASSAD, 2015).

Um sistema integrado de gestão de resíduos sólidos deve atuar em duas frentes fundamentais: a primeira é a obtenção de uma relação ótima entre os custos de redução da geração de resíduos na fonte e os custos de tratamento; a segunda é a indicação da melhor combinação entre as opções de destinação final disponíveis em acordo com a hierarquia para a gestão dos resíduos, a qual solidifica a rejeição da sociedade pelo aterramento. Ou, em outras palavras, a rejeição ao desperdício de recursos ao optar-se pelo simples aterramento em detrimento da reciclagem ou compostagem, por exemplo. (CHERMONT; SEROA DA MOTTA, 1996). 
De forma resumida, pode-se admitir o propósito de evitar a disposição dos resíduos em aterros como o cerne da hierarquia. Sendo assim, o ordenamento previsto corresponde ao potencial de cada uma das opções listadas de evitar o encaminhamento de resíduos para aterros. Deve-se atentar, porém, que há muitas incertezas em torno da equivalência deste ordenamento hierárquico com uma escala de impactos ambientais decorrentes da aplicação de cada opção. Ou seja, não há garantias de que as primeiras opções serão sempre as mais vantajosas em termos ambientais, pois peculiaridades locais afetam os impactos ambientais decorrentes de cada opção. (VAN EWIJK; STEGEMANN, 2016).

\section{Etapas da Hierarquia}

De acordo com Conn (1977), o conceito de redução de resíduos está associado a ações prévias à geração, tais como aspectos de produção e consumo. Por outro lado, as ações posteriores à geração, como a separação para reciclagem, enquadram-se em outra categoria denominada naquela época como recuperação de recursos.

Taylor (2000) indica três possibilidades para gestão dos resíduos. A primeira busca evitar a geração e abrange práticas com esse intuito, desde a fabricação dos produtos até as etapas de transporte e consumo, bem como iniciativas relativas ao reúso e às preferências do consumidor no momento da compra. Uma segunda possibilidade é evitar que os resíduos já descartados sejam destinados a aterros, essencialmente por meio da segregação nas fontes geradoras e posterior reciclagem, compostagem ou aproveitamento energético. A terceira opção é a disposição dos resíduos em aterros - aqui entendidos como aterros sanitários, devidamente adequados do ponto de vista ambiental.

Ainda de acordo com Taylor (2000), a minimização dos resíduos possui um caráter mais abrangente ao abarcar tanto as ações para evitar a geração dos resíduos quanto aquelas para evitar que os resíduos gerados sejam dispostos em aterros.

Não há ainda consenso a respeito da distinção entre os conceitos de minimização e prevenção. Autores como Cox et al. (2010) e Salhofer et al. (2008) adotam a definição da Organização para a Cooperação e Desenvolvimento Econômico (OECD), para a qual a prevenção diz respeito a não geração, ao reúso e à redução da periculosidade, enquanto o conceito de minimização seria mais amplo incluindo tanto a prevenção quanto a reciclagem. (HARJULA, 2002).

A prevenção da geração de resíduos remete à atenção na fonte geradora e inclui a não geração (evitar), redução e reúso, excluindo a reciclagem externa à fonte geradora. A compostagem doméstica poderia ser considerada assim uma ação de prevenção. (BARTL, 2014; ZORPAS; LASARIDI, 2013). 
Para Gentil, Gallo e Christensen (2011) a prevenção da geração, especialmente de resíduos de alimentos, pode produzir benefícios ambientais significativos, sobretudo nos locais onde a técnica de tratamento predominante é a disposição em aterros - caso do Brasil. Apesar de considerarem difíceis a implementação e o monitoramento de ações de prevenção, os autores sugerem a promoção dessas iniciativas como soluções efetivas no combate às emissões de gases de efeito estufa.

Corvellec (2016) classifica as iniciativas para prevenção da geração de resíduos em três categorias: conscientização, aumento da eficiência dos materiais e consumo sustentável. Para o autor, a conscientização é a primeira etapa da prevenção e trata basicamente de tornar a população ciente dos problemas decorrentes da geração de resíduos, bem como das atitudes que podem mitigar esses problemas.

A otimização da produção, consumo e descarte dos produtos é o cerne do aumento da eficiência dos materiais e visa reduzir a quantidade de resíduos gerados nesses processos e ao mesmo tempo facilitar o descarte e a reciclagem pós-consumo. Já as ações em torno do consumo consciente têm como objetivo promover mudanças no padrão atual ao incentivar o consumo de produtos usados ou mesmo a redução do consumo. (CORVELLEC, 2016).

\section{Críticas à hierarquia para a gestão dos resíduos}

Monitorar e avaliar a prevenção da geração dos resíduos são tarefas complexas, pois qualquer redução no montante de resíduos gerados poderia ser tida como resultado de ações preventivas, porém diversos outros fatores, como crises econômicas, também podem ocasionar quedas no consumo e, consequentemente, na geração de resíduos. (BARTL, 2014; ZORPAS; LASARIDI, 2013).

Reduzir o montante de resíduos gerados é sem dúvida uma ação representativa do ponto de vista dos ganhos ambientais potenciais. Porém, esse tipo de estratégia pode gerar conflitos de interesse entre os atores envolvidos, pois o consumo é o motor do crescimento econômico e inevitavelmente gera resíduos. (BARTL, 2014).

Incentivar a redução da geração também contraria os interesses dos operadores dos sistemas de gestão de resíduos, empresas de coleta e tratamento, que teriam seu mercado de atuação limitado em função da menor geração de resíduos. É preciso conciliar ${ }^{2}$ os diversos interesses envolvidos para potencializar o uso das estratégias de prevenção. Outro problema da hierarquia é colocar a prevenção como uma ferramenta para os gestores da área de resíduos que estão habituados a lidar com questões 
práticas do gerenciamento, como a coleta e o tratamento. (BARTL, 2014; VAN EWIJK; STEGEMANN, 2016; ZACHO; MOSGAARD, 2016).

A inclusão de uma opção na ordem de prioridade automaticamente legitima a adoção dessa opção. Assim, mesmo que ocupe o último lugar na ordem de prioridade, o uso dos aterros permanece válido de certa forma. A mensagem que se passa neste caso é muito menos impactante do que seria a proibição do uso de aterros para disposição de resíduos sólidos urbanos, por exemplo. Sendo assim, a hierarquia não promove mudanças radicais na gestão dos resíduos. Há, no entanto, interpretações de que ela deve ser vista como um guia da direção a ser seguida, levando a sociedade a subir gradativamente das últimas para as primeiras opções de gestão dos resíduos. (VAN EWIJK; STEGEMANN, 2016).

Por outro lado, Zacho e Mosgaard (2016) sugerem ser mais difícil ascender gradativamente na hierarquia da gestão dos resíduos que começar pelo topo dela. Localidades que efetuaram grandes investimentos em incineradores, por exemplo, dimensionados para uma determinada quantidade de resíduos, teriam maior resistência em incentivar ações de prevenção, uma vez que eventuais reduções no volume de resíduos poderiam inviabilizar a operação dessas plantas. (CORVELLEC, 2016).

Por essa mesma lógica, ao menos teoricamente, haveria menor resistência para efetivação de um planejamento que tenha a redução da geração dos resíduos como princípio norteador naquelas localidades onde não foram feitos grandes investimentos de longo prazo em tratamentos que ocupem a parte inferior da atual hierarquia preconizada para a gestão dos resíduos. (ZACHO; MOSGAARD, 2016).

Os critérios para adoção de uma determinada opção dentro da hierarquia devem estar claramente definidos. Historicamente são empregados argumentos oriundos de parâmetros como viabilidades técnica e econômica para justificar o emprego ou não da ordem hierárquica. (VAN EWIJK; STEGEMANN, 2016).

A PNRS, por exemplo, define rejeito como: resíduos sólidos que, depois de esgotadas todas as possibilidades de tratamento e recuperação por processos tecnológicos disponíveis e economicamente viáveis, não apresentem outra possibilidade que não a disposição final ambientalmente adequada (BRASIL, 2010a). Neste caso, a falta de viabilidade técnica ou econômica para a reciclagem de determinados tipos de resíduos pode ser utilizada como argumento para favorecer a disposição em aterros em detrimento das primeiras opções. Ao não explicitar o que 
configura exatamente a falta de viabilidade, deixa-se uma abertura para anular os efeitos da hierarquia da gestão dos resíduos. (VAN EWIJK; STEGEMANN, 2016).

Ações que podem potencializar a implementação da hierarquia são: a estruturação de sistemas de coleta de resíduos apropriados para aumentar o reúso e a reciclagem; estabelecimento de hierarquias específicas por tipo de resíduo; proibição ou taxação da disposição de determinados resíduos em aterros; e o estabelecimento de metas para reciclagem. (VAN EWIJK; STEGEMANN, 2016).

\subsection{POLITICAS PARA CONTROLE DA POLUIÇÃO}

No fim do século 20, as preocupações acerca dos recursos naturais se expandiram para além da gestão de recursos naturais, abarcando também a qualidade ambiental em seu escopo, qualidade essa diretamente afetada pela emissão de poluentes em corpos hídricos e na atmosfera, bem como pela disposição de resíduos no solo. Nessa linha, surgiram diversas contribuições cujo ponto central era o reconhecimento da limitada capacidade de resiliência do meio ambiente. (MUELLER, 1996; STAVINS, 2011).

Diferem-se, assim, a chamada economia dos recursos naturais e a economia da poluição. A primeira ocupando-se do controle intertemporal do uso de recursos naturais, tais como estoques minerais, florestais e pesqueiros. Já a segunda focada nos efeitos cumulativos da degradação ambiental decorrentes das atividades econômicas. De antemão, registra-se a grande dificuldade enfrentada pelo campo da economia da poluição na mensuração monetária dos danos ambientais.

Quando bens ou serviços ambientais são afetados pela poluição, perde-se qualidade ambiental. A ausência de direitos de propriedade sobre a maioria desses bens e serviços impossibilita a obtenção de uma compensação equivalente à perda sofrida junto aos agentes poluidores, o que configura uma externalidade negativa. Uma vez que os danos causados não implicam em custos para os agentes poluidores - não são precificados pelo mercado -, não há incentivos para a redução da poluição. (BAUMOL; OATES, 1988). A externalidade é um conceito básico da economia do meio ambiente e pode ser definida como o efeito involuntário e sem ação compensatória de uma determinada atividade sobre uma pessoa ou empresa. Outra possibilidade é compreendê-la como a ausência de direitos de propriedade e de mercados para os bens e serviços ambientais. (STERNER; CORIA, 2012).

As externalidades ocorrem por falhas no funcionamento do mercado. Na impossibilidade de ajustes por meio de preços, característica preponderante em bens de uso comum como os recursos e serviços 
ambientais, os agentes poluidores tendem a maximizar o seu lucro ao passo que as partes afetadas pela poluição têm o seu bem-estar reduzido pela perda da qualidade ambiental (ALMEIDA, 1998).

$\mathrm{Na}$ expectativa de controlar os impactos negativos da poluição, são propostas intervenções governamentais orientadas para correção das falhas de mercado. Essas intervenções são exercidas por meio de instrumentos validados ou instituídos por políticas públicas. A função deles é conformar o comportamento dos agentes no intuito de conter as externalidades negativas. (BAUMOL; OATES, 1988; SEROA DA MOTTA, 2006; STERNER; CORIA, 2012).

De acordo com Sterner e Coria (2012), usualmente, os intrumentos das políticas ambientais são classificados em apenas duas categorias: instrumentos de mercado e regulamentação direta comando e controle. Goulder e Parry (2008), por exemplo, citam a regulação direta e os instrumentos baseados em incentivos, mesmas categorias assinaladas por Almeida (1998).

Porém, ainda de acordo com Sterner e Coria (2012), a classificação em duas categorias é simplista, pois existem outras com propriedades distintas entre si. Sendo assim, os autores sugerem a adoção de uma matriz adaptada do trabalho do Banco Mundial (WORLD BANK, 1997), a qual se constitui de quatro categorias: usar mercados, criar mercados, regulações ambientais e engajando o público. (BERNARDO; NOGUEIRA, 2016; STERNER; CORIA, 2012).

A primeira categoria inclui as taxas e tarifas ambientais, além de outros instrumentos como subsídios e sistemas de depósito e reembolso. A segunda engloba os mecanismos atrelados à definição de direitos de propriedade, tais como as permissões negociáveis de poluição. Na terceira encontram-se os instrumentos de comando e controle. Já a última categoria inclui a participação pública, divulgação de informações e a rotulagem ambiental. (BERNARDO; NOGUEIRA, 2016; STERNER; CORIA, 2012).

\section{Regulações ambientais}

A abordagem mais tradicional para controle da poluição é a regulação direta. Mais conhecida como comando e controle, normalmente impõe aos agentes poluidores a adoção de padrões de emissão ou de tecnologias de controle da poluição, por meio de regulamentos. Assim, o agente regulador pode fixar um limite máximo de emissão de poluentes (padrões de emissão), bem como impor a adoção da melhor tecnologia disponível para controle da poluição. (STAVINS, 2011; STERNER; CORIA, 2012).

Os instrumentos de comando e controle permanecem como os mais presentes, talvez em função da sua relativa facilidade de compreensão e implementação. Outra explicação para a preponderância desses seria a resistência dos ambientalistas a alternativas de caráter econômico, tais como o 
provisionamento de direitos de propriedade, pois estes estabelecem "direitos de poluir" - uma noção controversa não apenas para ambientalistas. (KRUTILLA, 2011; STAVINS, 2011; STERNER; CORIA, 2012).

Para Almeida (1998), os instrumentos de comando e controle possuem natureza coercitiva e visam à adequação do comportamento dos agentes poluidores por meio do estabelecimento de normas e regulamentos, bem como punições ao descumprimento dessas normas. A inflexibilidade dos instrumentos de comando e controle embasa as críticas mais comuns à sua aplicação.

Nesse tipo de regulação, os padrões de emissão e as exigências tecnológicas são fixadas uniformemente, não se adaptam às variações de custos requeridos para sua implementação, o que depende de fatores como localização, tecnologia disponível e condições operacionais. O resultado, muitas vezes, é um custo de controle da poluição ineficiente, maior do que deveria. Em comparação com as taxas de emissão e com as permissões negociáveis de poluição, os instrumentos de comando e controle apresentam desvantagem em termos de custo-benefício. (GOULDER; PARRY, 2008; SCHMALENSEE; STAVINS, 2017; STAVINS, 2011).

\section{Usar/criar mercados}

Focada nas falhas de mercado e na ausência de direitos de propriedade, a teoria econômica tem feito significativas contribuções para o entendimento dos problemas ambientais, bem como para o desenvolvimento de polítcas públicas. Desprezar as contribuições da teoria econômica no momento da formulação das políticas pode levar à formatação de estratégias ineficientes e exacerbadamente onerosas. (STAVINS, 2011).

Ao se eleger a ausência de preços de mercado como o problema a ser combatido, a solução evidente parece ser precificar a externalidade negativa e impor esse custo ao agente poluidor. Conforme proposto por Pigou, isso poderia ser feito por meio de uma taxa atribuída aos agentes poluidores. (BAUMOL; OATES, 1988).

A taxação ambiental pura é denominada taxa pigouviana na medida em que seja equivalente aos danos causados pelos poluidores. A função da taxa é onerar os agentes poluidores, forçando-os assim a internalizarem os danos causados por suas atividades, acrescendo-os aos seus custos de produção. Para cada unidade de poluição deve ser instituída uma taxa equivalente aos custos sociais da poluição. Porém, apesar de parecer simples e constar como referência básica para as políticas ambientais, a 
aplicação da taxa requer muitas informações acerca dos custos de produção, da dinâmica dos serviços ambientais e de seu valor monetário. (STAVINS, 2011; STERNER; CORIA, 2012).

Determinar o nível ótimo de redução da poluição, no qual os custos marginais sociais se equiparem aos benefícios marginais sociais, requer a estimativa detalhada de custos e benefícios da produção e do controle da poluição, o que excede a capacidade habitual de muitas instituições governamentais encarregadas do controle da qualidade ambiental. (SERÔA DA MOTTA; HUBER; RUITENBEEK, 1999).

A taxação pode ser admitida como uma forma direta de precificar a poluição. Todavia, também é possível alcançar a precificação da poluição de forma indireta por meio de instrumentos de mercado como as permissões negociáveis de poluição, cuja fundamentação teórica remonta ao trabalho de Ronald Coase, no qual a poluição é admitida como um problema decorrente de falhas nos direitos de propriedade. A principal vantagem da aplicação desses tipos de instrumentos seria a minimização dos custos para controle da poluição. (SCHMALENSEE; STAVINS, 2017; STAVINS, 2011).

As licenças negociáveis de poluição, como os créditos de carbono, talvez sejam as principais expoentes dessa categoria de políticas. De acordo com Schmalensee e Stavins (2017), apesar dos instrumentos com essa natureza já terem provado eficácia em termos ambientais e econômicos, ainda estão longe de alcançar a amplitude de uso dos instrumentos tradicionais, como a taxação e as regulações diretas. Instrumentos de mercado têm o potencial de: reduzir os custos de manutenção da conformidade com a legislação; reduzir custos administrativos do governo; aumentar a qualidade ambiental; reduzir as emissões de substâncias tóxicas; reduzir custos com saúde pública; e contribuir para sustentabilidade das instituições públicas ao permitir melhores relações custo-benefício no controle da poluição. (SERÔA DA MOTTA; HUBER; RUITENBEEK, 1999).

Porém, como também ocorre com os instrumentos de comando e controle, limitações institucionais podem restringir a implementação dos instrumentos de mercado. A aplicação requer instituições fortes, legislação adequada, monitoramento e fiscalização. A mera substituição das regulações de comando e controle por instrumentos de mercado não suprime a relevância das instituições públicas na implementação das políticas ambientais, nem diminui por si só, as incertezas em relação ao funcionamento da legislação. (SERÔA DA MOTTA; HUBER; RUITENBEEK, 1999).

Para Serôa da Motta; Huber e Ruitenbeek (1999), a motivação inicial para adoção de instrumentos de mercado na América Latina atendeu primordialmente a uma necessidade de arrecadação e não ao controle da poluição. De acordo com os autores, as experiências no continente apontam para a 
complementariedade entre os instrumentos de comando e controle e de mercado, estes últimos contribuindo para geração de recursos financeiros requeridos para implementação das regulamentações diretas.

Goulder e Parry (2008) apontam para a ausência de um procedimento objetivo para escolha do melhor instrumento para aplicação das políticas ambientais. Embora concluam pela inexistência de um instrumento claramente superior aos outros disponíveis para aplicação das políticas ambientais, os autores também destacam o volume expressivo de estudos que apoiam o uso de políticas flexíveis, baseadas em incentivos.

\section{Engajando o público}

O custo de disseminação de informações caiu consideravelmente com o desenvolvimento das atuais tecnologias de comunicação, dessa forma os formuladores de política parecem ter um papel central na provisão de estruturas para facilitar o fluxo das informações, especialmente nas situações em que há muitas incertezas ou assimetrias de informação. Todas as políticas precisam de informação para serem implementadas, e as ferramentas associadas à transparência da informação têm sido aplicadas onde as políticas tradicionais têm falhado. A depender da forma de uso, pode se prover informações de várias formas tais como a certificação, rotulagem ambiental e a transparência pública. (STERNER; CORIA, 2012).

Os instrumentos de comunicação ou informação têm como princípio motivador prover informações com o intuito de influenciar o público alvo na adoção de comportamentos em prol do meio ambiente, estão inclusos nessa categoria relatórios e diagnósticos de qualidade ambiental (MAGALHÃES, 2016).

Schultz (2014) argumenta que o uso da informação como estratégia para disseminação de determinadas práticas e comportamentos é indicado apenas quando não se observam grandes barreiras para execução dessas práticas e os benefícios com sua adoção são claramente perceptíveis.

\section{INSTRUMENTOS PARA A GESTÃO DOS RESÍDUOS}

Toda atividade econômica está sujeita a produção de resíduos, logo, esse é um tópico contumaz na lista das externalidades mais relevantes. A disposição desses resíduos de forma inadequada ocasiona a contaminação do solo e dos corpos hídricos, além de emitir gases de efeito estufa. Mesmo as formas de tratamento consideradas adequadas, como o uso de aterros sanitários e da incineração, ainda impactam na qualidade ambiental. Dessa forma, muitos esforços são direcionados ao reaproveitamento dos resíduos por meio da reciclagem, processo que nem sempre é viável em termos 
econômicos. (BAUMOL; OATES, 1988; CHERMONT; SEROA DA MOTTA, 1996; SEROA DA MOTTA; SAYAGO, 1998; STERNER; CORIA, 2012).

O que deve ser reciclado, qual a motivação e quais políticas devem ser aplicadas para tanto permanecem em discussão. Um problema a ser destacado é a tendência de queda do custo de produção de muitos bens industrializados em função dos avanços tecnológicos - o que reduz o interesse econômico pela sua reciclagem. Materiais relativamente escassos tendem a ser mais valorizados e assim são espontaneamente reciclados, por outro lado, há pouca demanda pela reciclagem de materiais abundantes ou com baixo custo de produção. Características socioeconômicas também são determinantes nesse processo, em países de baixa renda a coleta de determinados tipos de resíduos é uma atividade econômica representativa para segmentos da sociedade. (STERNER; CORIA, 2012).

À luz da teoria econômica, por uma mistura de falhas de mercado e de governo, os geradores de resíduos não arcam com os custos marginais de todo o processo de coleta, tratamento e disposição final dos resíduos sólidos urbanos. Essas falhas poderiam ser corrigidas por meio da aplicação de instrumentos que permitissem a internalização dos custos sociais dessas atividades. (CHERMONT; SEROA DA MOTTA, 1996).

A literatura econômica tem sugerido diversas opções de políticas públicas, porém poucas foram implementadas conforme as prescrições teóricas. Algumas presunções foram confirmadas por estudos empíricos, tais como as relações inversamente proporcionais entre os preços cobrados por unidade de lixo coletada e demanda pela coleta e diretamente proporcionais entre nível de renda e a geração de resíduos. Por outro lado, aspectos comportamentais ainda precisam ser melhores compreendidos, como as motivações em prol da reciclagem, pois muitas vezes os indivíduos apresentam comportamentos proativos mesmo na ausência de incentivos. (KINNAMAN; FULLTERTON, 1999).

\subsection{INSTRUMENTOS DE COMANDO E CONTROLE}

Regulações de comando e controle dizem respeito ao estabelecimento de padrões explícitos para minimização da geração dos resíduos que devem ser cumpridos por geradores, operadores e gestores que ficam sujeitos a penalidades em caso de descumprimento dos padrões determinados. O sucesso da implementação dos instrumentos de comando e controle depende da motivação dos indivíduos em aderir a determinadas regulamentações, sendo que baixa motivação significa implementação lenta 
e execução onerosa. Tal problema poderia ser minimizado aliando outros tipos de instrumentos como incentivos sociopsicológicos e econômicos - ao uso dos instrumentos de comando e controle. (TAYLOR, 2000).

Os instrumentos de comando e controle foram largamente aplicados à gestão dos resíduos. Porém, questionamentos contra esse tipo de instrumento versam sobre a sua eficácia como indutor de mudanças de comportamento e as dificuldades para fixação dos objetivos e padrões a serem alcançados. Além disso, a necessidade de informações precisas e de estruturas eficientes de gerenciamento e controle podem representar custos exacerbados. (CHERMONT; SEROA DA MOTTA, 1996).

Kirakozian (2016) argumenta que instrumentos de natureza regulatória, quando aplicados isoladamente, são falhos para alcançar a redução da geração de resíduos ou mudar o comportamento dos consumidores.

Taylor (2000) cita as seguintes regulações como exemplos de instrumentos de comando e controle voltados para a gestão de resíduos:

a) Proibição de uso de lixões a céu aberto e de disposição de resíduos de podas e jardinagem em aterros sanitários;

b) Estabelecimento de padrões de controle para aterros sanitários (tais como o licenciamento e as normas técnicas);

c) Obrigação de participação em estratégias para redução na fonte e segregação dos resíduos como a logística reversa e a coleta seletiva;

d) Metas para reciclagem por tipo de material e controle do montante de resíduos recicláveis e não segregados dispostos em aterros;

e) Especificações com relação à durabilidade dos produtos;

f) Proibição de fabricação de determinados tipos de embalagens e produtos;

g) Definição da quantidade de material reciclado a ser utilizada na fabricação de produtos novos. 


\subsection{INSTRUMENTOS SOCIOPSICOLÓGICOS}

Muitos estudos indicam que os incentivos econômicos não são os únicos fatores capazes de influenciar o nível de participação da sociedade em programas de reciclagem. Atributos como conveniência e satisfação moral podem ter grande relevância, é justamente nesse nicho que se situam os incentivos sociopsicológicos. São políticas de curto prazo que objetivam incitar mudanças no comportamento dos geradores de resíduos com vistas a facilitar a reciclagem ou reduzir a geração de resíduos. A ideia é imbuir no público-alvo uma motivação que faça com que os comportamentos desejados sejam praticados costumeiramente. Grande parte desses instrumentos faz uso de ferramentas de comunicação. (TAYLOR, 2000).

De acordo com Taylor (2000) são exemplos de incentivos sociopsicológicos as seguintes inciativas:

a) A disseminação de informações a respeito das políticas e programas de minimização da geração de resíduos;

b) Comunicação persuasiva que busca associar os objetivos da redução da geração a valores pessoais como bem-estar e família;

c) Incentivos de curto prazo tais como prêmios e concursos;

d) Comprometimento perante outros atores para adotar comportamentos de minimização da geração;

e) Abordagens com base na pressão social, quando a maior parte de um bairro age de determinada maneira as pessoas quem não se enquadram naquele comportamento tendem a sentir um desconforto;

f) Uso de líderes comunitários e empresariais que motivam os outros indivíduos a assumir determinadas posturas;

g) Envolvimento da população no desenvolvimento dos programas de redução da geração provocando um sentimento de obrigação naqueles que contribuíram para elaboração do programa;

h) Aumentar a conveniência de quem deseja alcançar os objetivos de redução da geração (provimento de lixeiras em quantidade adequada).

Para Dai et al. (2016) e Xu et al. (2016), apesar da larga utilização por governos, há muitos registros na literatura a respeito da pouca efetividade das estratégias baseadas na provisão de informação. Como 
estratégias de mobilização social, os autores defendem a adoção de abordagens menos impessoais que promovam a participação de voluntários em interação com a comunidade, por exemplo.

Mesmo considerando o baixo valor dos resíduos como a principal causa da falta de engajamento para a reciclagem, Sterner e Coria (2012) argumentam que as questões comportamentais e motivacionais devem ser consideradas, afinal, muitas pessoas se engajam em programas de reciclagem sem receberem incentivos para tanto, a satisfação moral e a aprovação social podem explicar esse comportamento.

\subsection{INSTRUMENTOS ECONÔMICOS}

Os instrumentos econômicos atrelam a adoção de comportamentos desejáveis à perda ou ganho de benefícios. Incentivos econômicos estão relacionados à motivação para adoção de comportamentos e visam corrigir falhas de mercado na gestão dos resíduos oriundas da natureza da cobrança pelo serviço - não proporcional - e pela não internalização dos custos sociais da destinação dos resíduos. A aplicação dos instrumentos econômicos permite minimizar a geração de resíduos e aumentar a reciclagem de forma flexível e com menor custo para sociedade, e ainda pode representar uma fonte de recursos para financiar ações na área. (GODECKE et al., 2012; MAGALHÃES, 2016; TAYLOR, 2000).

Para Seroa da Motta e Sayago (1998), os instrumentos econômicos podem ter um viés de controle (menos flexíveis) ou de mercado (mais flexíveis) e a sua aplicação no campo da gestão dos resíduos sólidos tem se expandido internacionalmente. Ao menos em teoria, a solução ideal para a gestão dos resíduos seria a definição de um preço equivalente ao custo marginal de sua coleta e disposição, ou seja, estabelecer uma taxa ou tarifa para a gestão dos resíduos.

De acordo com Kinnaman (2016), o debate em torno dos instrumentos econômicos aplicáveis à gestão dos resíduos esteve completamente centrado na internalização dos custos da disposição dos resíduos e, geralmente, assinala os sistemas de depósito retorno como a melhor opção para executar essa tarefa.

Schultz (2014) aponta os incentivos como ferramentas efetivas, porém, o autor alerta que a aplicação de instrumentos com essa natureza exige ponderações acerca dos custos operacionais e da condicionalidade do comportamento aos incentivos, tendo em vista se tratarem de motivações externas aos indivíduos - recompensas ou penalidades instituídas pelo governo -, que ao serem removidas podem implicar na interrupção do comportamento desejado. 
Taylor (2000) cita cinco categorias de instrumentos econômicos aplicáveis à gestão dos resíduos como as mais utilizadas: subsídios públicos, tarifas para disposição, impostos sobre produtos, sistemas de depósito/retorno, e a cobrança dos usuários.

\section{Subsídios}

Subsídios incluem financiamentos e empréstimos para ações que os geradores não estariam dispostos a assumir por conta própria, tais como compra de maquinário, melhoria de instalações e desenvolvimento de tecnologias. Também podem ser aplicadas desonerações tributárias, créditos fiscais e taxas para estimular o uso de matéria prima reciclada. (TAYLOR, 2000).

Cabe citar como exemplo de subsídio para reciclagem no Brasil a Lei 12.375/2010, a qual outorgava ${ }^{3}$ aos estabelecimentos industriais um crédito presumido do Imposto sobre Produtos Industrializados IPI na aquisição de resíduos sólidos utilizados como matérias-primas ou produtos intermediários na fabricação de seus produtos. A validade do benefício estava condicionada à compra de materiais recicláveis diretamente de cooperativas de catadores de materiais recicláveis.

\section{Tarifas para disposição}

Tarifas para disposição de resíduos em aterros ou incineradores são pagas pelos operadores dos serviços de manejo que assim internalizam o custo social da disposição. Essa tarifação é amplamente praticada nos Estados Unidos e na Europa. Em comparação com a cobrança dos usuários domésticos, elas são mais fáceis de implementar tendo em vista a quantidade limitada de operadores, o que reduz custos administrativos. Outra vantagem é a possibilidade de se estabelecer a cobrança proporcional à quantidade de resíduos gerada, bem como diferenciá-la de acordo com o potencial poluidor de cada resíduo. Contudo, a fixação da tarifa pode estimular o aumento da disposição de resíduos de forma inadequada, especialmente nos países em desenvolvimento. (CHERMONT; SEROA DA MOTTA, 1996; KINNAMAN, 2010; TAYLOR, 2000).

\section{Impostos sobre produtos}

Os impostos sobre produtos visam internalizar os custos da gestão pós-consumo de produtos e suas embalagens. A ideia é fazer com que os custos de gerenciamento de alguns tipos de resíduos, bem como os custos sociais de sua disposição final, sejam internalizados por meio de um imposto cuja incidência ocorra sobre o produto, antes que este se torne resíduo. Em suma, esse mecanismo permite estimular a redução do consumo de materiais cujos impactos ao meio ambiente sejam mais significativos ao passo em que altera a estrutura de preços do mercado. Por outro lado, deve se atentar 
para o fato de que este instrumento, por si só, não incentiva comportamentos em prol da reciclagem. (CHERMONT; SEROA DA MOTTA, 1996; KINNAMAN; FULLTERTON, 1999; TAYLOR, 2000)

\section{Sistemas depósito/retorno}

Incentivar tanto a redução da geração como a reciclagem é o objetivo dos sistemas de depósito/retorno ao combinarem o uso de um imposto sobre o produto com um subsídio para reciclagem. Por meio desse instrumento, o consumidor fica sujeito ao pagamento de um imposto no ato da compra do produto, porém o valor pago pode ser reembolsado no momento do descarte pósconsumo - desde que este seja efetuado em locais previamente definidos. Embalagens de bebidas são os itens mais comuns sob regime desse tipo de instrumento. (TAYLOR, 2000).

Sistemas de depósito/retorno podem ser instituídos de forma impositiva, por meio de obrigações legais, ou de forma voluntária, quando os ganhos dos fabricantes com o reúso ou reciclagem dos produtos retornados superam os custos de operacionalização do sistema. Nesse sistema, pelo menos dois ônus recaem sob o consumidor: os custos com as despesas operacionais do sistema podem ser repassados a eles via aumento de preços; cabem aos consumidores arcar com os custos relativos ao esforço necessário para descartar os produtos nos locais pré-estabelecidos. Cabe lembrar, no entanto, que os ganhos sociais com a reciclagem podem superar esses custos. (CHERMONT; SEROA DA MOTTA, 1996; TAYLOR, 2000).

Ao simularem a aplicação de três políticas públicas para reduzir a disposição de resíduos em aterros, Palmer, Sigman e Walls (1997) assinalaram a adoção de sistemas de depósito/retorno como a opção menos onerosa em comparação com os subsídios para a reciclagem e impostos sobre produtos. Para as autoras, no entanto, caso incorram altos custos administrativos para a manutenção desse sistema, os impostos sobre produtos podem ser uma alternativa mais vantajosa. Deve-se atentar para a relação entre os custos de implantação de cada uma dessas políticas e os benefícios sociais decorrentes de sua aplicação, neste caso específico foram considerados como benefícios os custos evitados com transporte e disposição de resíduos.

\section{Cobrança dos usuários}

A cobrança dos usuários diz respeito à existência de um encargo, visível aos geradores, que represente todos os custos da gestão dos resíduos. Há um problema quando os custos desse serviço são cobertos de forma indireta por outros impostos arrecadados pelo governo - o que ocorre com frequência no Brasil -, pois, ao não entrar em contato com os custos da gestão dos resíduos, os usuários não são 
incentivados a minimizar a geração. (BERSCH; PRAÇA; TAYLOR, 2017; CHERMONT; SEROA DA MOTTA, 1996).

O que se observa na maioria dos casos onde se instituíram taxas para a gestão dos resíduos é que essa cobrança não é proporcional à quantidade de resíduos gerada. Dessa forma, gerar muito ou pouco resíduo implica no mesmo custo para o consumidor, assim não há incentivo para a redução da geração. Porém, deve se atentar para a situação dos países em desenvolvimento, nos quais a ausência de sustentabilidade financeira nos sistemas de gestão de resíduos - muito em função da limitada capacidade de pagamento da população por esse serviço - permanece como um desafio a ser superado. (CHERMONT; SEROA DA MOTTA, 1996; WILSON et al., 2015)

Segundo estimativas do Diagnóstico do Manejo de Resíduos Sólidos Urbanos - 2016, a cobrança específica para os serviços de gestão de resíduos é efetuada por pouco mais de $30 \%$ dos municípios brasileiros. Dentro desse universo de municípios que obtêm receitas por meio da cobrança, $77 \%$ arrecadam menos da metade dos recursos necessários para consecução das atividades de manejo dos resíduos. (BRASIL, 2018).

A cobrança pode ser efetuada de forma homogênea, quando todos os usuários pagam uma quantia semelhante pelo serviço de coleta e destinação, ou de forma proporcional quando se paga pela quantidade de resíduos gerada. O nível ótimo de geração de resíduos seria alcançado no ponto em que os benefícios marginais da redução na fonte geradora se igualassem aos custos marginais de gerenciamento e destinação final. Porém, o emprego de um mecanismo baseado nessa lógica depende da implantação de um sistema de cobrança proporcional ao montante de resíduos gerado por cada indivíduo, o que é complexo, especialmente para os resíduos domésticos. (CHERMONT; SEROA DA MOTTA, 1996; TAYLOR, 2000).

Há evidências de que o estabelecimento da cobrança pela gestão dos resíduos de forma proporcional à quantidade gerada é uma estratégia eficiente para prevenir a geração, pois essa se apresenta como uma forma de recompensa para aqueles indivíduos que cooperam com a reciclagem ou buscam minimizar o total de resíduos gerados. No entanto, deve-se atentar para possíveis efeitos negativos decorrente da aplicação desse instrumento, tais como o aumento da disposição irregular. (KIRAKOZIAN, 2016).

A cobrança pela gestão dos resíduos deve ser proporcional à quantidade gerada, caso contrário, beneficia-se a parcela da população que não assume atitudes condizentes com as estratégias para redução da geração, configurando-se assim como um desincentivo para quem busca contribuir com a 
minimização da quantidade de resíduo. Características como essas, somadas à ausência de taxas para a disposição em aterros sanitários, prejudicam a adoção de estratégias para a redução e prevenção da geração, pois, sem o apoio de instrumentos econômicos, a disposição se apresenta como uma alternativa de tratamento muito barata. (PUIG-VENTOSA; SASTRE SANZ, 2017).

\subsubsection{CRIAÇÃO DE MERCADOS}

A aplicação deste tipo de instrumentos no campo da gestão de resíduos sólidos é recente. Conforme Chermont e Seroa da Motta (1996), metas de reciclagem definidas por meio de regulamentações poderiam ser alcançadas por meio da emissão de certificados comercializáveis de reciclagem, porém naquele momento os autores não encontraram registros deste tipo de instrumento.

Sterner e Coria (2012) citam como exemplo um sistema em operação no Reino Unido, o qual se baseia na emissão de títulos de recuperação de embalagens. Por meio desse sistema, recicladores acreditados recebem títulos de recuperação de embalagens referentes ao montante reciclado por eles. Os títulos podem ser negociados com as empresas que estão obrigadas por lei a cumprirem metas de recuperação de embalagens. São características marcantes desse sistema a partilha de custos entre os envolvidos e o impulso à indústria da reciclagem.

No Brasil é possível citar a iniciativa da Bolsa Verde do Rio de Janeiro, a qual desenvolveu um sistema de emissão de créditos de logística reversa. Adaptado à realidade brasileira, os créditos são concedidos a cooperativas de catadores de materiais recicláveis credenciadas que podem negociá-los com as empresas que queiram cumprir sua obrigação legal de recolhimento de embalagens por meio desse sistema. Não foram encontrados estudos que detalhem melhor esse sistema e os seus resultados. (ZELLER, 2014)

\subsubsection{ALGUMAS CONSIDERAÇÕES}

Kling, Seyring e Tzanova (2016) indicam o uso de sistemas de cobrança proporcionais como o primeiro instrumento a ser aplicado para melhoria do desempenho de sistemas de gestão de resíduos. Os autores enfatizam, porém, os altos custos envolvidos na operacionalização desse sistema e apontam as tarifas para disposição em aterros como uma opção alternativa.

Kinnaman (2010) também defende o uso de tarifas para disposição em aterros ao invés da cobrança unitária pela gestão dos resíduos. Para o autor, pesam contra a cobrança dos usuários os altos custos administrativos, a tendência à disposição de forma irregular como alternativa ao pagamento da taxa 
e a falta de estímulos para que unidades de triagem centralizadas aumentem a sua eficiência. A fixação de uma tarifa equivalente ao custo marginal externo da coleta e disposição dos resíduos de forma eficiente eliminaria a necessidade de outras regulações, como a obrigatoriedade de separação dos resíduos ou subsídios para reciclagem.

Mais recentemente, Kinnaman (2016) sugeriu que os custos marginais externos da disposição em aterro são relativamente baixos em relação aos benefícios marginais externos da reciclagem. Dessa forma, maiores esforços deveriam ser direcionados ao dimensionamento dos benefícios que a reciclagem proporciona ao reduzir a demanda por recursos naturais utilizados como matéria-prima.

Enfatizar a preservação de recursos naturais como uma externalidade positiva da reciclagem suscita uma reavaliação de instrumentos usuais, tais como a taxa para gestão dos resíduos, sistemas de depósito retorno, impostos sobre produtos e responsabilidade estendida do produtor (logística reversa), os quais têm como foco a internalização dos custos sociais do uso de aterros. Tal mudança de ponto de vista sugere a utilização de subsídios para a reciclagem como forma de internalizar os benefícios dessa atividade. (KINNAMAN, 2016).

Chermont e Seroa da Motta (1996), ao abordarem a reciclagem, reforçam a necessária avaliação do custo benéfico dessa atividade, o que deve incluir os benefícios sociais. Porém, os autores não consideram os benefícios auferidos ao se evitar a extração de recursos naturais quando se prioriza a reciclagem, de qualquer maneira concluem que a atividade de reciclagem deve receber incentivos equivalentes aos custos por ela evitados.

Em estimativa elaborada pelo Instituto de Pesquisa Econômica Aplicada - IPEA, os potenciais benefícios alcançados com a reciclagem de papel, plástico, aço, alumínio e vidro oriundos dos resíduos sólidos urbanos no Brasil podem chegar a R\$ 8 bilhões por ano. (IPEA, 2010).

A carência de recursos nos países em desenvolvimento é lembrada por Sterner e Coria (2012) como uma dificuldade para implementação das políticas ambientais com base em instrumentos de mercado. Por outro lado, as regulamentações também exigem grandes esforços para se fazerem cumprir, tendo em vista as diligências necessárias para monitorar o cumprimento da lei, bem como punir as infrações.

\subsection{A ESCOLHA DOS INSTRUMENTOS DAS POLÍTICAS PÚBLICAS}

Dentro do campo da formulação de políticas públicas, os instrumentos podem ser compreendidos como elementos que estruturam a ação pública com vistas a alcançar os objetivos de uma política. 
Nesse sentido, são os meios pelos quais o Estado impõe os padrões de conduta demandados para a resolução de problemas públicos. (CAPELLA, 2018)

Uma política, tal qual a PNRS, além de objetivos e princípios também apresenta um rol de instrumentos para solucionar o problema público - nesse caso específico são dezenove - os quais foram definidos na fase de formulação da política. Porém, para implementar essa política, apenas alguns desses instrumentos serão de fato adotados. Sendo assim, previamente, há uma tomada de decisão cujo principal objetivo é escolher os instrumentos que serão aplicados. (HOWLETT; RAMESH; PERL, 2013).

A tomada de decisão na política pública recebeu bastante atenção nos primórdios das ciências políticas. Na década de 1960 as discussões sobre o tema giravam em torno de dois modelos teóricos: o racional e o incremental. O modelo racional previa que o tomador de decisão adotaria procedimentos, baseados em critérios técnicos e racionais, para a escolha do instrumento mais eficiente possível. Já naquela época, porém, surgiram muitas críticas ao modelo racional, questionando a factibilidade de fazer escolhas plenamente racionais em qualquer situação, tendo em vista limitações como disponibilidade de tempo e informações. (CAPELLA, 2018; HOWLETT; RAMESH; PERL, 2013)

Um dos críticos mais notórios ao modelo racionalista foi o economista Hebert Simon. Para ele, decisões não são feitas apenas com base na racionalidade fundada na maximização da utilidade conforme pressupostos da economia neoclássica. Esse processo é limitado por fatores como a complexidade do ambiente de escolha, a disponibilidade de informações, além de atributos psicológicos do tomador de decisão. (BALESTRIN, 2013; HOWLETT; RAMESH; PERL, 2013; SBICCA, 2014).

A complexidade do ambiente de escolha está diretamente relacionada à nossa capacidade limitada de processar grandes quantidades de informação. A obtenção de informações tem grande relevância para a escolha, pois requer pesquisa, tempo e esforço, o que representa custos. Já os atributos psicológicos estão relacionados às percepções de mundo que podem ser bem diferentes da realidade. (SBICCA, 2014).

Para Simon, o ser humano usa atalhos para lidar com a complexidade em torno da tomada de decisão. Especialistas não analisam exaustivamente a relação custo-benefício das opções disponíveis para reduzir a quantidade de alternativas possíveis, satisfazem-se com o atendimento de poucos critérios estabelecidos no momento da escolha. (HOWLETT; RAMESH; PERL, 2013; SBICCA, 2014). 
Na esteira dos trabalhos de Simon, muitos pesquisadores se dedicaram à identificação dos vieses que afetariam os tomadores de decisão em ambientes de muitas incertezas. As heurísticas procedimentos que auxiliam nossa busca por respostas para questões de difícil julgamento - são objeto de estudos de Amos Tversky e Daniel Kahneman. Ao se deparar com uma pergunta complexa, que envolva probabilidades, por exemplo, nossa mente oferece uma resposta rápida - não necessariamente correta -, que na verdade é a resposta de alguma outra pergunta, mais simples que a original. Para Kahneman (2012) tudo o que nossa mente procura é uma história coerente, adequada às nossas crenças:

[...] nem a quantidade nem a qualidade da evidência contam muito para a confiança subjetiva. A confiança que os indivíduos depositam em suas crenças depende principalmente da qualidade da narrativa que podem contar acerca do que veem, mesmo se veem pouco. Muitas vezes deixamos de levar em conta a possibilidade de que a evidência que deve ser crítica para nosso julgamento esteja faltando. (KAHNEMAN, 2012, p. 114)

Uma dessas heurísticas é a da representatividade: a tendência de ignorar a real probabilidade de ocorrência de um evento diante de uma aparente coerência contextual. Esse efeito afeta nosso julgamento em situações tais como a probabilidade de que um evento $A$ se origine de um processo $B$. $\mathrm{Na}$ ausência de informações adicionais, ao encontrar evidências na descrição do processo B que o correlacione ao evento $A$, a tendência é se apegar a essa informação e, por conseguinte, supuser como alta a probabilidade de que o evento A se origine do processo B. (KAHNEMAN, 2012).

De posse de poucas informações para fundamentar uma decisão, estamos propensos a supervalorizar a evidência que estiver disponível, ainda que esta não tenha confiabilidade. O mais impressionante é que esse efeito permanece mesmo quando dados a respeito das reais probabilidades dessa ocorrência são evidentes. Ou seja, tomamos a decisão com base na representatividade da correlação identificada - quanto mais coerente em nosso entendimento, mais forte - e não nas informações probabilísticas recebidas (KAHNEMAN, 2012).

O conceito de racionalidade limitada desenvolvido por Simon foi incorporado pelo modelo incremental, o qual compreende a tomada de decisão como um processo político de barganha entre os tomadores de decisão. Nesse modelo, proposto pelo cientista político Charles Lindblom, a tomada de decisão representa o possível, aquilo que é viável politicamente, e não aquilo que é tecnicamente mais eficaz. Outra característica desse modelo é que as decisões tomadas em geral não diferem consideravelmente das decisões anteriores, há uma tendência de manutenção do status quo ou de 
efetivação de poucas alterações - de onde surge a alcunha incrementalista atribuída a esse modelo. (HOWLETT; RAMESH; PERL, 2013).

Para além do racionalismo e incrementalismo, outro modelo se destacou ao atribuir uma completa irracionalidade ao processo decisório. Trata-se do modelo da cesta de lixo desenvolvido por James March e Johan Olsen. De acordo com esse modelo, muitas vezes os tomadores de decisão nem sequer se apropriam dos objetivos ou têm alguma compreensão a respeito das consequências relacionadas às diferentes escolhas possíveis. A metáfora da cesta de lixo ressalta o caráter imprevisível desse processo ao conceber a imagem de uma cesta onde os tomadores de decisão colocam problemas e soluções na medida em que eles vão surgindo. As organizações influenciam o conteúdo da cesta, detêm preferências a respeito das soluções e operam na base da tentativa e erro. (HOWLETT; RAMESH; PERL, 2013; SOUZA, 2006).

Para autores como Linder e Peters (1989), o cerne da questão está na percepção que os atores têm dos instrumentos. O contexto do tomador de decisão exerce grande influência na escolha, uma vez que este possui uma visão limitada dos instrumentos disponíveis - o que pode ocorrer devido a limitações de qualificação ou mesmo pela presença de algum viés ideológico, dentre outros fatores. A percepção também está relacionada com a interpretação do problema a ser resolvido, diferentes pontos de vista a respeito do problema podem levar a diferentes escolhas em termos de instrumentos para solucioná-lo.

Outra corrente de pesquisa, bastante influente na literatura de origem francesa, reconhece a força das normas sociais, representações e crenças, as quais compõem uma espécie de matriz cognitiva e normativa derivada do contexto e das percepções dos atores envolvidos no processo de formulação de políticas. Assim, a preferência por um determinado instrumento não é um mero procedimento técnico, ela é profundamente influenciada pelas concepções de mundo dos atores que irão promovêla. (MULLER, 2018).

Uma política pública é uma representação da realidade na qual se pretende intervir. Em referência a essa imagem cognitiva os atores organizam sua percepção do problema, confrontam suas soluções e definem suas propostas de ação. Ou seja, a política pública fornece uma imagem, uma visão de mundo a partir da qual obtém-se uma leitura da realidade e das formas de intervenção para esse contexto. (MULLER, 2018). 
Muller (2018) chama isso de referencial, é a partir dele que serão definidos critérios de escolha e significação de objetivos. O referencial articula quatro níveis de percepção do mundo: valores, normas, algoritmos e imagens.

Os valores são as representações mais fundamentais sobre o que está bem ou mal, o que é desejável e o que deve ser rejeitado, eles definem um quadro geral da ação pública. As normas definem as diferenças entre a realidade percebida e a realidade desejada. Elas definem princípios de ação mais do que de valores, por exemplo: "a agricultura tem de se modernizar", "é necessário reduzir os custos em saúde". Os algoritmos são relações causais que expressam uma teoria da ação. Eles podem ser anunciados sob a forma "se... então": "se o governo reduzir os impostos das empresas, então elas serão mais competitivas", exemplificando. As imagens - o jovem agricultor dinâmico e moderno - são vetores implícitos nos valores, de normas ou mesmo algoritmos. São atalhos cognitivos que fazem sentido imediatamente. (MULLER, 2018).

Para Lima e D’Ascenzi (2013), grande parte dos estudos sobre implementação de políticas públicas baseiam-se em uma abordagem sequencial, na qual a formulação e a implementação são vistas como processos isolados. Nessa perspectiva, incentivos e constrangimentos à ação dos atores são tidos como determinantes na fase de implementação. Porém, de acordo com os autores, a compreensão do processo perpassa tanto as condições e limitações materiais que constrangem as decisões dos atores quanto os aspectos cognitivos na apropriação das ideias expressas por uma política.

Dessa forma, a ação de implementação é entendida como uma consequência da interpretação dos objetivos de uma política feita pelos atores responsáveis. A intenção expressa na política é apropriada pelos atores envolvidos no processo de execução de acordo com sua visão de mundo e contexto de trabalho. Os autores propõem um modelo analítico fundado na avaliação de três aspectos: as características da política; o contexto organizacional; e os valores, ideias e concepções dos atores envolvidos no processo. (LIMA; D'ASCENZI, 2013).

Böcher (2012) propõe um modelo teórico para explicar a escolha de políticas ambientais, o qual mistura elementos da teoria da escolha racional com efeitos das percepções dos agentes envolvidos e de fatores institucionais. Para o autor, a escolha dos instrumentos resulta das interações entre esses três fatores condensados nas seguintes categorias analíticas: 
Instituições: diz respeito à tradição política, ao estilo da regulação. Fatores institucionais limitam ou expandem as alternativas em termos de instrumentos. Mudanças tendem a ocorrer quando a estrutura do problema muda.

Estrutura do problema: quais são as características do problema que essa política pública visa solucionar. Instrumentos de comando e controle parecem responder melhor a problemas que exigem respostas rápidas, por exemplo. Já problemas difusos e de longo prazo, como as mudanças climáticas, exigem outros tipos de instrumento. Mudanças na percepção do problema a ser resolvido direcionam as discussões em torno dos instrumentos mais adequados para solucioná-lo. Também deve-se considerar a distribuição de custos e benefícios entre os diferentes grupos de interesse envolvidos no processo. Governos têm dificuldades de implementar instrumentos econômicos, pois eles dão visibilidade aos custos individuais.

Discursos sobre as alternativas de instrumentos: Dois tipos de discurso científico/especializado e discursos politicamente carregados. Além da racionalidade científica, os instrumentos de política também são altamente influenciados por fatores políticos, simbólicos, ideológicos ou mesmo morais. A percepção pública dos instrumentos alternativos depende dos discursos públicos no qual está inserido. $\mathrm{O}$ avanço do neoliberalismo com o discurso de menos regulação ajudou a promover o uso de instrumentos econômicos na Alemanha.

Atores e a situação de decisão: os atores políticos não agem sempre de forma racional como prediz a teoria da escolha pública. Esses atores podem ser egoístas, mas também compartilham ideias, experiências, motivações intrínsecas e tradições. A decisão desses atores é afetada por incertezas e por uma base limitada de conhecimento. Porém, eles podem aprender e isso pode reduzir incertezas no processo de escolha dos instrumentos. Destaca-se o papel dos empreendedores políticos que trazem novas ideias, mobilizam a opinião pública e obtêm suporte político. (BÖCHER, 2012, grifo nosso, tradução nossa)

\subsubsection{CRITÉRIOS DE ESCOLHA}

Até aqui pudemos perceber que o processo de tomada de decisão não corresponde a uma tarefa puramente racional, muito pelo contrário, está sujeita a diversos constrangimentos de caráteres cognitivo, institucional e contextual. Sendo assim é imperativa a adoção de critérios técnicos para reduzir a subjetividade nessas escolhas. Nogueira e Pereira (2000).

Nogueira e Pereira (2000) propõem duas ferramentas para fundamentar a escolha dos instrumentos de política ambiental. A primeira é o emprego de critérios de seleção a partir dos quais sepode avaliar a adequação dos instrumentos de políticas ambientais (educação ambiental, controle direto, impostos/taxas) ao contexto de aplicação. São indicados oito critérios de análise: eficácia, eficiência, motivação, custo administrativo, aceitação política, equidade, mínimo de interferência e confiabilidade. Ao fazer uso dessa matriz de critérios, o tomador de decisão pode fundamentar sua 
escolha comparando vantagens e desvantagens de cada categoria de instrumento a partir de critérios preestabelecidos.

Cabe ao responsável pela tomada de decisão atribuir pesos relativos aos critérios empregados decidir quais critérios terão maior relevância no momento da escolha. Essa ponderação exige uma leitura acerca do contexto de aplicação dos instrumentos, bem como dos problemas a serem combatidos. Por essa razão, a aplicação dos critérios por si só não garante uma escolha apropriada, nesse sentido também é desejável a adoção de ferramentas complementares, procedimentos decisórios. (NOGUEIRA; PEREIRA, 2000)

Os mesmos autores também abordaram dois procedimentos analíticos para tomada de decisão: Análise Custo Benefício - ACB e Análise Custo Efetividade - ACE. A primeira opção (ACB) exige maior quantidade de informações, se apresentando assim como uma opção de complexa execução. Já a ACE apresenta-se com uma opção mais versátil devido à sua simplicidade. Os passos para realização desses dois tipos de análise estão condensados na tabela 01:

TABELA 1 - ETAPAS DE DESENVOLVIMENTO DA ACB E ACE

\begin{tabular}{|c|c|c|}
\hline Etapa & ACB & ACE \\
\hline 1 & $\begin{array}{l}\text { Definição de uma função objetivo } \\
\text { ou meta ambiental }\end{array}$ & $\begin{array}{l}\text { Definição de uma função objetivo ou } \\
\text { meta ambiental }\end{array}$ \\
\hline 2 & $\begin{array}{l}\text { Identificar as opções existentes } \\
\text { para que a meta ambiental } \\
\text { estabelecida seja alcançada }\end{array}$ & $\begin{array}{l}\text { Identificar as opções existentes para que } \\
\text { a meta ambiental estabelecida seja } \\
\text { alcançada }\end{array}$ \\
\hline 3 & $\begin{array}{l}\text { Estabelecimento dos custos das } \\
\text { diferentes opçôes }\end{array}$ & $\begin{array}{l}\text { Estimativa da efetividade real das opções } \\
\text { de programas }\end{array}$ \\
\hline 4 & $\begin{array}{l}\text { Identificação dos tipos de } \\
\text { benefícios }\end{array}$ & Avaliação do custo-efetividade \\
\hline 5 & $\begin{array}{l}\text { Levantamento e/ou estimativa dos } \\
\text { benefícios }\end{array}$ & \\
\hline 6 & $\begin{array}{l}\text { Avaliação da razão } \\
\text { custo/benefício }\end{array}$ & \\
\hline
\end{tabular}

Fonte: (NOGUEIRA; PEREIRA, 2000) 
No Brasil predomina a ausência de critérios ou procedimentos para escolha dos instrumentos ambientais. Esse cenário pode explicar a prevalência de instrumentos de comando e controle e educação ambiental até os dias de hoje, pois, sem critérios, o processo de escolha tende a se manter alinhado a decisões anteriores, além de se sujeitar a questões subjetivas dos tomadores de decisão e interesses privados. (NOGUEIRA; PEREIRA, 2000).

De qualquer forma, deve-se ter em mente a complexidade envolvida na formulação das políticas ambientais e escolha dos instrumentos para sua aplicação, o que exige a associação entre conhecimentos de ecologia, economia e legislação. As políticas ambientais não estão fora da arena de disputa de interesses políticos e econômicos, e a ausência de instituições fortes pode desequilibrar essa disputa a favor de certos grupos de interesses, levando à formatação de políticas ineficazes ou até mesmo contraproducentes. (GOULDER; PARRY, 2008; SERÔA DA MOTTA; HUBER; RUITENBEEK, 1999; STERNER; CORIA, 2012).

\section{A HIERARQUIA PARA GESTÃO DOS RESÍDUOS E OS INSTRUMENTOS ECONÔMICOS EM}

\section{DIFERENTES ESFERAS DE GOVERNO}

\subsection{ESFERA FEDERAL}

A PNRS, em conjunto com o seu regulamento (Decreto 7.404/2010), compõe o grande marco regulatório da gestão dos resíduos no Brasil, motivo pelo qual éo ponto de partida do presente levantamento. A lei traz um conjunto de princípios, objetivos, instrumentos e diretrizes relativas à gestão integrada e ao gerenciamento de resíduos sólidos, os quais estão subordinados à hierarquia para a gestão dos resíduos. Segundo Machado (2012, p. 30), “a obrigação legal prioritária de não gerar resíduo mostra fortemente a reutilização e a reciclagem como as opções da política brasileira de resíduos sólidos". Para o autor, a hierarquia representa uma "ordem com força legal".

Nesse diploma, a hierarquia para a gestão dos resíduos consta simultaneamente como um objetivo, previsto no inciso II do artigo 70: "São objetivos da Política Nacional de Resíduos Sólidos: [...] II - não geração, redução, reutilização, reciclagem e tratamento dos resíduos sólidos, bem como disposição final ambientalmente adequada dos rejeitos"; e como uma diretriz alocada no artigo 9o: "Na gestão e gerenciamento de resíduos sólidos, deve ser observada a seguinte ordem de prioridade: não geração, redução, reutilização, reciclagem, tratamento dos resíduos sólidos e disposição final ambientalmente adequada dos rejeitos." 
Ainda nas diretrizes aplicáveis aos resíduos sólidos, a PNRS dedica um capítulo (capítulo V) aos instrumentos econômicos no qual a ordem hierárquica é frisada novamente:

Art. 42. O poder público poderá instituir medidas indutoras e linhas de financiamento para atender, prioritariamente, às iniciativas de: I - prevenção e redução da geração de resíduos sólidos no processo produtivo; II desenvolvimento de produtos com menores impactos à saúde humana e à qualidade ambiental em seu ciclo de vida; III - implantação de infraestrutura física e aquisição de equipamentos para cooperativas ou outras formas de associação de catadores de materiais reutilizáveis e recicláveis formadas por pessoas físicas de baixa renda; IV - desenvolvimento de projetos de gestão dos resíduos sólidos de caráter intermunicipal ou, nos termos do inciso I do caput do art. 11, regional; $\vee$ - estruturação de sistemas de coleta seletiva e de logística reversa. (BRASIL, 2010a)

A forma de implementação desses instrumentos é explicitada no Decreto 7.404/2010:

Art. 80. As iniciativas previstas no art. 42 da Lei no 12.305 , de 2010, serão fomentadas por meio das seguintes medidas indutoras: I - incentivos fiscais, financeiros e creditícios; II - cessão de terrenos públicos; III - destinação dos resíduos recicláveis descartados pelos órgãos e entidades da administração pública federal às associações e cooperativas dos catadores de materiais recicláveis, nos termos do Decreto no 5.940, de 25 de outubro de 2006; IV subvenções econômicas; $V$ - fixação de critérios, metas, e outros dispositivos complementares de sustentabilidade ambiental para as aquisições e contratações públicas; VI - pagamento por serviços ambientais, nos termos definidos na legislação; e VII - apoio à elaboração de projetos no âmbito do Mecanismo de Desenvolvimento Limpo - MDL ou quaisquer outros mecanismos decorrentes da Convenção Quadro de Mudança do Clima das Nações Unidas. (BRASIL, 2010b)

A respeito desses instrumentos nota-se que a lei abre um leque de opções de incentivos que devem ser concedidos prioritariamente a iniciativas de prevenção ou redução da geração e nos processos produtivos e para a recuperação de materiais recicláveis com a participação dos catadores e por meio de sistemas de coleta seletiva e logística reversa. Quanto à natureza dos instrumentos, percebe-se uma ênfase em torno dos subsídios.

Após essa breve incursão no âmago da Política Nacional de Resíduos Sólidos, pode-se inferir que a ordem de prioridade para a gestão dos resíduos deve permear todo o corpo da PNRS, uma linha de raciocínio que encontra amparo na interpretação da exposta por Machado (2012). Além disso, para o autor, ao evocar o princípio da prevenção em seu art. 6으, a Lei realça a importância dos instrumentos de planejamento, uma vez que a sua implementação tem como objetivo principal prevenir danos ambientais.

A exigência do planejamento é um dos cernes da PNRS. Para consecução deste objetivo a Lei prevê a elaboração de planos de resíduos sólidos em escalas federal, estadual e municipal, além de outras 
escalas regionais quando aplicável. Os planos definem as estratégias e diretrizes para o alcance dos objetivos estabelecidos pela Lei, o plano nacional deve servir ainda como balizador para o planejamento dos outros entes federados. (OLIVEIRA; GALVÃO JUNIOR, 2016).

Tendo em vista o exposto, este trabalho também inclui o exame da versão preliminar do Plano Nacional de Resíduos Sólidos, do Plano Estadual de Resíduos Sólidos de Goiás e do Plano Municipal de Gestão de Integrada de Resíduos Sólidos de Goiânia. Nos termos da lei, os planos de resíduos sólidos devem incluir metas atreladas à redução, reutilização e reciclagem com vistas a reduzir a quantidade de resíduos e rejeitos encaminhados para disposição final ambientalmente adequada, em linha com a hierarquia da gestão dos resíduos. (MACHADO, 2012).

O estabelecimento de metas se enquadra como um típico instrumento de comando e controle, porém, nesse caso específico, deve se atentar ao fato de que a lei não estipula metas diretamente, estas devem constar nos planos de resíduos. Porém, planos, por si só, não possuem caráter coercitivo, não têm poder para impor obrigações. Para que o conteúdo de um plano tenha força legal, ele precisa ser incorporado ao arcabouço legal nos níveis federal, estadual ou municipal.

Publicado em 2012 como uma versão preliminar, o Plano Nacional de Resíduos Sólidos ilustra bem essa situação, tendo em vista nunca ter sido oficialmente internalizado como instrumento de governo - o que deveria ser feito por meio de um decreto federal nos termos do Decreto 7.404/2010. Além das metas exigidas pelo PNRS, essa versão do plano apresenta diretrizes específicas para:

a) Redução da geração de resíduos sólidos urbanos;

b) Redução dos resíduos sólidos urbanos secos dispostos em aterros sanitários e inclusão de catadores de materiais reutilizáveis e recicláveis;

c) Redução de resíduos sólidos urbanos úmidos dispostos em aterros sanitários, e tratamento e recuperação de gases em aterros sanitários.

Importante destacar nesse ponto a distinção colocada pelo plano, pois a primeira diretriz diz respeito a evitar, reduzir a geração total de resíduos, algo mais próximo da prevenção. Já as duas diretrizes seguintes fazem menção direta à redução da disposição em aterros sanitários, uma se referindo aos resíduos secos, onde se inclui a fração reciclável - cuja recuperação deve incluir os catadores de materiais recicláveis - e a outra focada nos resíduos úmidos que representam a maior parte dos resíduos sólidos urbanos no Brasil. (SIQUEIRA; ASSAD, 2015). 
Como estratégias para redução dos resíduos sólidos urbanos secos dispostos em aterros sanitários e inclusão de catadores de materiais reutilizáveis e recicláveis o Plano Nacional indica os seguintes instrumentos de caráter econômico:

a) Incentivos (fiscais, financeiros e creditícios) voltados ao incremento da reciclagem no país;

b) E equacionamento das demandas por alterações tributárias (bitributação, isenções etc.), visando o estímulo a reutilização e reciclagem de uma maneira geral.

\subsection{ESFERA ESTADUAL}

Deixando a esfera federal para adentrar no Estado de Goiás, registra-se a presença de uma política estadual de resíduos sólidos - PERS, a Lei 14.248/2002. Apesar de ter sido editada oito anos antes da PNRS, essa política também busca impor uma hierarquia baseada na prevenção da geração dos resíduos, o que pode ser constatado logo em seu segundo artigo:

Art.2. São princípios da Política Estadual de Resíduos Sólidos: [...] VIII - a prevenção da poluição, mediante práticas que promovam a redução ou eliminação de resíduos na fonte geradora; [...] IX - a minimização dos resíduos, por meio do incentivo às práticas ambientalmente adequadas de reutilização, reciclagem e recuperação, e que busquem evitar sua geração. (GOIÁs, 2002)

A ordem hierárquica propriamente dita consta no art. 10 da política:

Art. 10. A gestão dos resíduos sólidos observará: I - a prevenção da poluição, a eliminação, ou, pelo menos a redução da geração de resíduos na fonte e a minimização dos resíduos gerados; II - a recuperação ambientalmente segura de materiais ou de energia dos resíduos ou produtos descartados; III - o tratamento ambientalmente seguro dos resíduos; IV - a disposição final ambientalmente segura dos resíduos remanescentes; $V$ - a recuperação das áreas degradadas pela disposição inadequada dos resíduos. (GOIÁs, 2002)

Mesmo utilizando terminologias diferentes da PNRS, a ordem hierárquica não difere do conceito universal que preconiza a não geração como prioridade máxima da gestão e disposição final como a última opção. Merece atenção a inclusão da recuperação das áreas degradadas pela disposição de resíduos como um dos itens a serem observados na gestão dos resíduos, pois este tipo de ação não consta entre as atividades típicas da gestão dos resíduos. Todavia, incluir essa obrigação como uma incumbência dos responsáveis pela gestão dos resíduos enseja uma discussão a respeito da internalização dos custos sociais da disposição em aterros sanitários.

Na categoria de instrumentos econômicos listados pela PERS é possível notar novamente uma tendência em favor dos subsídios: 
Art. 61. Deverão ser concedidos incentivos fiscais e financeiros para que as instituições públicas e privadas: I - promovam a minimização dos resíduos a serem dispostos e, preferencialmente, adotem métodos de prevenção, eliminação, ou, pelo menos, redução, reutilização e reciclagem de resíduos; II estimulem, mediante programas específicos, a implantação de unidades de coleta, triagem, beneficiamento e reciclagem; III - estimulem a produção de produtos com alto rendimento, duráveis, recicláveis, reutilizáveis, retornáveis, passíveis de conserto, reaproveitáveis, que não sejam perigosos e/ou tóxicos;

[...] parágrafo único - os incentivos fiscais e financeiros de que trata este artigo serão concedidos sob a forma de créditos especiais, deduções, isenções, total ou parcial de impostos, tarifas diferenciadas, prêmios, empréstimos e demais modalidades especificamente estabelecidas. (GOIÁS, 2002)

Publicado em 2016, o plano de resíduos do Estado de Goiás também inclui diretrizes em acordo com a hierarquia para a gestão dos resíduos, as quais parecem estar em consonância com o plano nacional:

a) Reduzir a geração per capita;

b) Reduzir a disposição de resíduos reutilizáveis e recicláveis (secos) nos aterros sanitários;

c) Incentivar e acompanhar a inclusão socioeconômica, na rota tecnológica dos resíduos sólidos reutilizáveis e recicláveis, dos catadores cadastrados;

d) Reduzir os resíduos orgânicos (úmidos) nos aterros sanitários sem aproveitamento energético.

Destaca-se aqui a coerência entre essas diretrizes e os presentes no plano nacional, sendo a única diferença a ênfase conferida à inclusão dos catadores de materiais recicláveis, tema que recebe item exclusivo no plano de Goiás. O que de qualquer forma não muda o enfoque original dado à reciclagem com a participação desses atores e vai ao encontro do incentivo federal concedido na forma do crédito presumido do IPI que também privilegia os catadores de materiais recicláveis conforme consta na Lei $12.375 / 2010$.

\subsection{ESFERA MUNICIPAL}

Já na esfera municipal, o presente panorama sublinha o plano de resíduos de Goiânia - PMGIRS e a Lei 9.498/2014 (Lei do grande gerador), a qual dispõe sobre a cobrança de preço público decorrente da prestação de serviços de coleta, transporte e destinação final de resíduos sólidos produzidos por grandes geradores, bem como seu regulamento, o Decreto 728/2016.

No PMGIRS nota-se novamente a distinção entre as diretrizes voltadas para os resíduos secos e para os resíduos úmidos, esse plano, no entanto, não faz referência à redução da geração de resíduos logo nos títulos de suas diretrizes, pois parece prevalecer um caráter mais pragmático e detalhado na 
formulação das diretrizes e estratégias, talvez em função da característica de executor da política de gestão de resíduos que recai sobre o município. Para os resíduos secos, o PMGIRS propõe as seguintes diretrizes:

Diretriz 01: Implantar/otimizar o sistema de coleta seletiva do município.

Diretriz 02: Implantar/Ampliar rede de áreas de recebimento de materiais recicláveis, ecopontos, de pequenos geradores.

Diretriz 03: Tornar a coleta dos resíduos domiciliares secos presente em todos os setores de atividade e na totalidade do território da cidade, envolvendo uma coleta seletiva rigorosa em todos os bairros e a participação dos pequenos e grandes geradores. (GOIÂNIA, 2016, p. 338)

Para os resíduos úmidos, são indicadas as seguintes diretrizes:

Diretriz 01: Desenvolver programa de coleta seletiva de RSD ${ }^{4}$ Úmidos em ambientes com geração homogênea (feiras, sacolões, restaurantes e outros), promovendo seu tratamento;

Diretriz 02: Reduzir significativamente o volume de RSD Úmidos no aterro. (GOIÂNIA, 2016, p. 341)

Para os resíduos secos, fica explícito o enfoque na reciclagem por meio da coleta seletiva e de pontos de entrega voluntária (ecopontos). A prevenção, abordada no plano nacional e no estadual, não é mencionada aqui, o que também pode estar relacionado à característica de execução do Município, na qual questões operacionais assumem papel de relevância em comparação com outros aspectos mais ligados ao planejamento, como a prevenção da geração de resíduos.

Em relação aos resíduos úmidos, nota-se a ênfase nos grandes geradores, o que facilita a coleta e tratamento dos resíduos, pois o grau acentuado de geração, bem como a homogeneidade dos resíduos gerados em atividades, como as das centrais de distribuição de alimentos e das feiras livres, permite a adoção de práticas baseadas no tratamento in loco desses resíduos, o que representa vantagens em relação ao modelo tradicional de tratamento centralizado e tem grande potencial de reduzir a disposição em aterros. (SIQUEIRA; ASSAD, 2015).

A lei do grande gerador do Município de Goiânia - Lei 9.498 - foi publicada em 2014, porém o seu Decreto regulador, sem o qual a Lei não poderia ser aplicada, só foi editado em 2016. O propósito da Lei é revelado logo em seu primeiro artigo: 
Art. 10 Os resíduos sólidos, caracterizados como resíduos de Classe 2, de acordo com a NBR 10.004, da Associação Brasileira de Normas Técnicas (ABNT), produzidos por grandes geradores, poderão ser coletados e transportados, pelos interessados, para o local de tratamento e destinação final, previamente designado pelo ente gerenciador dos serviços públicos de limpeza urbana da municipalidade ou coletados, transportados, tratados e destinados por este ente, mediante a cobrança de preço público específico, fixado por ato do Chefe do Poder Executivo. (GOIÂNIA, 2014)

Lei visa onerar os grandes geradores de resíduos, obrigando-os a contratar um serviço específico para coleta, tratamento e disposição final dos resíduos gerados em seus estabelecimentos. Dessa forma, os geradores devem internalizar os custos de transporte e tratamento dos resíduos gerados, o que em tese funciona como um incentivo à redução da geração, desde que a cobrança seja proporcional à quantidade de resíduos gerada.

A Lei do grande gerador representa a aplicação de um instrumento de natureza econômica com potencial de fazer valer a hierarquia para a gestão dos resíduos, conforme preconiza a PNRS. Além da cobrança pela gestão dos resíduos, a Lei também impõe uma espécie de tarifa pela disposição no aterro sanitário, conforme prescreve o Decreto 728/2016:

Art. 8o O Poder Público Municipal, por intermédio do ente gerenciador, deverá oferecer aos Grandes Geradores ou às empresas por eles contratadas, aterro sanitário regularmente licenciado para a disposição final dos rejeitos.

$\S 1$ o A empresa prestadora de serviço, ao utilizar o aterro sanitário, disponibilizado pela Administração Municipal para disposição final dos rejeitos, o fará mediante prévio pagamento de preço público no valor estipulado, na forma deste Decreto. (GOIÂNIA, 2016b)

A tarifa pela disposição dos resíduos é outro instrumento econômico capaz de promover a internalização dos custos da gestão dos resíduos e assim incentivar comportamentos tais como a reciclagem e o reúso, porém, conforme destacado pela literatura, as tarifas devem ser fixadas de forma proporcional ao montante de resíduos destinado ao aterro, bem como incluir os custos sociais decorrentes da adoção deste tipo de destinação.

\section{COMPONDO UM REFERENCIAL PARA A PNRS}

Até aqui, constatou-se que o conceito da redução da geração dos resíduos permeia os principais regulamentos concernentes ao Estado de Goiás e ao Município de Goiânia. Tal situação indica, ao menos em princípio, que este conceito fundamental para as políticas modernas de gestão de resíduos foi absorvido de maneira uniforme pelos instrumentos de planejamento e regulação nos diferentes níveis federativos. 
Já em relação aos instrumentos de natureza econômica - foco deste trabalho - notam-se referências, especialmente aos subsídios, nas legislações nacional e estadual, bem como no Plano Nacional. 0 mesmo não ocorre com os planos de resíduos nas esferas estadual e municipal, que não exploram a aplicação dessa categoria de instrumento.

Como explicar a ausência de recomendações em torno de instrumentos econômicos no plano de resíduos do Goiânia? Certamente não se trata da falta de previsão legal como demonstra a análise da legislação. Não se trata também da disponibilidade, pois é farta a oferta de ferramentas dentro desta categoria de instrumentos.

Em busca de uma resposta para essa pergunta, apoiou-se conceitualmente na abordagem cognitiva da análise de políticas públicas, sobretudo na noção de referencial proposta por Muller (2018). Qual a percepção dos atores envolvidos na formulação do plano de resíduos? Há uma imagem pré-concebida da PNRS a partir da qual esses atores fundamentam suas decisões?

A fim de demarcar um referencial, uma visão de mundo embutida nas ideias difundidas em torno da PNRS, primeiramente analisamos o discurso do então Presidente da República, Luiz Inácio Lula da Silva, durante cerimônia de sanção da Política Nacional de Resíduos Sólidos em 2010.

\subsection{O DISCURSO PRESIDENCIAL}

Em discurso durante a cerimônia de sanção da PNRS, em 2 de agosto de 2010, o então Presidente da República, Luiz Inácio Lula da Silva, evoca a questão social e a importância da nova Lei para os catadores de materiais recicláveis:

A adoção de uma lei nacional para disciplinar o manejo adequado dos resíduos sólidos é uma revolução em termos ambientais. Ela organiza uma série de instrumentos que estavam dispersos sem, no entanto, perder de foco a principal questão, que é a questão social. A Política Nacional de Resíduos Sólidos trata da preservação ambiental e da proteção da saúde pública. Seu maior mérito, contudo, é a inclusão social de trabalhadores e trabalhadoras humildes que, durante muitos anos, foram esquecidos e maltratados pelo poder público brasileiro. Nesse sentido, ela está de acordo com a missão, que nosso governo assumiu, de fazer o Brasil crescer para todos, reduzindo as desigualdades sociais e preservando o meio ambiente. (BRASIL, 2010c)

De fato, a inclusão dos catadores é citada pela PNRS em diversos momentos, o que é fruto da atuação política de grupos, como o Movimento Nacional dos Catadores de Materiais Recicláveis - MNCR ${ }^{5}$, que vem representando esses atores tão presentes no cotidiano das cidades brasileiras. Trata-se, portanto, de um aspecto inegavelmente relevante da política. 
Sendo assim, muitos investimentos foram efetuados no intuito de potencializar o trabalho dos catadores e assim avançar com o objetivo da PNRS. Ainda no discurso presidencial, destaca-se a necessidade de mudança no comportamento da sociedade, no sentido de que os geradores de resíduos devem estar conscientes de seu papel na defesa do meio ambiente e dos catadores de materiais recicláveis.

A geração de resíduos sólidos, nos dias de hoje, é um fato inevitável. Mas podemos evitar as suas consequências desastrosas. Da mesma forma, podemos evitar a repetição do descaso que condenou famílias inteiras a uma existência sub-humana nos lixões das grandes cidades. E essa questão não é responsabilidade exclusiva dos governos. Todos que produzem e consomem bens geradores de resíduos sólidos precisam estar a cada dia mais conscientes de seu papel na defesa de nosso meio ambiente e dos direitos dos milhares de cidadãos que trabalham na cadeia da reciclagem. (BRASIL, 2010c).

A conscientização dos geradores de resíduos - entende-se aqui como toda a sociedade - é vista como um caminho para evitar eventuais consequências ambientais, bem como para melhorar as condições de vida dos catadores de materiais recicláveis.

O discurso presidencial evidenciou a questão social como o eixo central da PNRS e não a questão ambiental. O objetivo do governo, ao menos o que se ressaltou como discurso, não era disciplinar a gestão de resíduos no intuito de reduzir a disposição em aterros, conforme podemos inferir da hierarquia para gestão dos resíduos, e sim promover a inclusão social dos catadores de materiais recicláveis ao disciplinar a gestão dos resíduos. Na busca desse objetivo, a conscientização da sociedade surge como instrumento de destaque.

A ênfase na educação ambiental e no apoio aos catadores não era nenhuma novidade no momento da promulgação da PNRS, pois já existiam no âmbito do Governo Federal dois importantes marcos referentes a essas questões: a Política Nacional de Educação Ambiental (1999) e o Comitê Interministerial da Inclusão Social de Catadores de Lixo (2003).

\subsection{POLÍTICA NACIONAL DE EDUCAÇÃO AMBIENTAL}

Publicada onze anos antes da PNRS, a Política Nacional de Educação Ambiental - PNEA, Lei № 9.795, de 27 de abril de 1999, traz em seu primeiro artigo a seguinte definição:

Entendem-se por educação ambiental os processos por meio dos quais o indivíduo e a coletividade constroem valores sociais, conhecimentos, habilidades, atitudes e competências voltadas para a conservação do meio ambiente, bem de uso comum do povo, essencial à sadia qualidade de vida e sua sustentabilidade. (BRASIL, 1999) 
Dentre os objetivos listados pelo artigo quinto da PNEA, chama atenção o terceiro, o qual relaciona o aspecto social à problemática ambiental: "o estímulo e o fortalecimento de uma consciência crítica sobre a problemática ambiental e social." (BRASIL, 1999)

Evidencia-se assim a consolidação, no âmbito do Governo Federal, de uma certa compreensão da conscientização/educação ambiental como instrumento de enfrentamento das questões sociais e ambientais, visão bastante evidenciada no discurso de sanção da PNRS pronunciado onze anos após a edição da PNEA.

\subsection{COMITÊ INTERMINISTERIAL DA INCLUSÃO SOCIAL DE CATADORES DE LIXO}

Instituído por Decreto em 11 de setembro de 2003, o Comitê Interministerial da Inclusão Social de Catadores de Lixo tinha como finalidade:

I - implementar o Projeto Interministerial Lixo e Cidadania: Combate à Fome Associado à Inclusão de Catadores e à Erradicação de Lixões, visando garantir condições dignas de vida e trabalho à população catadora de lixo e apoiar a gestão e destinação adequada de resíduos sólidos nos Municípios; II - articular as políticas setoriais e acompanhar a implementação dos programas voltados à população catadora de lixo; III - definir mecanismos de monitoramento e avaliação da implantação das ações articuladas que deverão atuar de forma integrada nas localidades. (BRASIL, 2003)

Já em 2003, institucionalizava-se, de certa forma, a ideia de que apoiar os catadores de materiais recicláveis representava ao mesmo tempo a promoção da destinação adequada de resíduos e o combate às desigualdades sociais.

Em 2010, mesmo ano da promulgação da PNRS, foi editado o Decreto № 7.405, de 23 de dezembro de 2010, que criou o Programa Pró-Catador e reestruturou o Comitê Interministerial da Inclusão Social de Catadores de Lixo, passando a denominá-lo como Comitê Interministerial para Inclusão Social e Econômica dos Catadores de Materiais Reutilizáveis - CIISC.

Nos termos do Decreto № 7.405, o programa pró-catador visa a melhoria das condições de trabalho dos catadores de materiais recicláveis, bem como ampliar as oportunidades de inclusão social desse segmento, persistindo na ideia de que tais ações também representariam ganhos no âmbito da coleta seletiva e da reciclagem. 
[...] integrar e articular as ações do Governo Federal voltadas ao apoio e ao fomento à organização produtiva dos catadores de materiais reutilizáveis e recicláveis, à melhoria das condições de trabalho, à ampliação das oportunidades de inclusão social e econômica e à expansão da coleta seletiva de resíduos sólidos, da reutilização e da reciclagem por meio da atuação desse segmento. (BRASIL, 2010d)

Pereira e Teixeira (2011) apontam ainda como medidas relevantes da agenda em torno dos catadores de materiais recicláveis: o decreto 5.940 de 2006, que institui a separação dos resíduos recicláveis descartados pelos órgãos e entidades da administração pública federal direta e indireta, na fonte geradora, e a sua destinação às associações e cooperativas dos catadores de materiais recicláveis e; a Lei $11.445 / 07$, que altera a Lei de licitações, incluindo a possibilidade de dispensa de licitação na contratação de organizações de catadores de materiais recicláveis para a prestação de serviços de coleta seletiva.

Em termos de diplomas legais cabe citar também a Lei 12.375, de 30 de dezembro de 2010, a qual cria o crédito presumido do Imposto sobre Produtos Industrializados - IPI na aquisição de resíduos sólidos utilizados como matérias-primas ou produtos intermediários na fabricação de seus produtos. Trata-se de um instrumento econômico, um subsídio, aplicado à cadeia da reciclagem. Porém, em consonância com o momento político vivido no país, tal subsídio destinava-se apenas aos resíduos sólidos adquiridos diretamente de cooperativas de catadores de materiais recicláveis.

Conforme relatam Pereira e Teixeira (2011), a pauta social ganhou grande relevância com a ascenção do governo do Partido dos Trabalhadores - PT, criando um cenário favóravel ao protagonismo dos catadores de materiais recicláveis, o que explica a agenda pública formada em torno desses atores.

Com a mudança de governo em 2003, uma das características foi uma maior abertura e diálogo do governo Lula com a sociedade civil - traços do histórico de relações do PT com movimentos sociais. Além disso, a agenda governamental posta pelo governo Lula foi voltada para políticas sociais, como, por exemplo, os programas Fome Zero, Bolsa Família, Prouni, entre outros. Soma-se a isso um ambiente nacional favorável e com grandes expectativas em torno das políticas públicas do novo governo, sobretudo aquelas voltadas para questões sociais. Em suma, o fluxo da política era favorável e abria oportunidades à inserção de temas na agenda, como a inclusão produtiva e social de catadores. (PEREIRA; TEIXEIRA, 2011, p. 908)

\subsection{PLANO DE AÇÃO PARA PRODUÇÃO E CONSUMO SUSTENTÁVEIS}

Em 2011, o Ministério do Meio Ambiente lançou o Plano de Ação para Produção e Consumo Sustentáveis - $\mathrm{PPCS}^{6}$, que trazia como uma de suas metas o aumento da reciclagem de resíduos 
sólidos. Logo em sua apresentação, o plano deixa claro suas pretensões em relação aos resíduos sólidos:

Além de ter a meta de aumentar a reciclagem - o que não será possível sem um considerável esforço para obter a cooperação do consumidor, portanto da população, a união da PNRS com o PPCS pode estruturar uma vigorosa indústria da reciclagem no Brasil, gerando milhares de postos de trabalho, além de fortalecer os programas de inclusão dos catadores. (BRASIL, 2011, n.p)

Conforme expresso no PPCS, para aumentar a reciclagem era fundamental a cooperação da população, a expansão da indústria da reciclagem e a inclusão dos catadores. Dentro desse âmbito, o plano propôs as seguintes ações:

1. Adotar a meta do PNMC: aumentar a reciclagem no país em $20 \%$ até 2015 e $25 \%$ até 2020;

2. Estimular, por meio de instrumentos diversos, a criação de mercado para recicláveis;

3. Realizar ações de educação ambiental, especificamente voltadas à temática da coleta seletiva e da atuação dos catadores junto à população atendida, visando o fortalecimento da imagem do catador e a valorização de seu trabalho na comunidade;

4. Apoiar o alcance das metas do Programa Brasileiro de Eliminação de HCFCs $\mathrm{PBH}$, do MMA, por meio de parcerias com o setor privado;

5. Estimular o desenvolvimento de estudos e instrumentos de desoneração da cadeia para produtos que contenham materiais reciclados na sua composição;

6. Elaboração de materiais didáticos e campanhas dirigidas sobre os impactos da geração de resíduos sólidos, buscando sensibilizar para a importância da reciclagem. (BRASIL, 2011, p. 48)

No item 2, é importante observar a indefinição quanto aos instrumentos para a criação do mercado de reciclagem, o texto faz referência a "instrumentos diversos". Nessa mesma linha, o item 5 fala em "estimular o desenvolvimento de estudos e instrumentos de desoneração". Tal situação contrasta com o item 6, no qual são propostas ações específicas como a elaboração de materiais didáticos e campanhas de sensibilização para a importância da reciclagem.

\subsection{CONFERÊNCIA NACIONAL DO MEIO AMBIENTE}

A IV Conferência Nacional do Meio Ambiente, realizada em 2013, mobilizou mais de 200 mil pessoas em todo o país para discutir a implementação da PNRS. O ápice da conferência foi a plenária em Brasília, realizada em outubro de 2013, com a presença de 1.352 delegados indicados nas etapas estaduais do evento. Trata-se, portanto, de um grande esforço democrático de participação social. 
O objeto da conferência - implementação da Política Nacional de Resíduos Sólidos - foi explorado a partir de quatro eixos temáticos: produção e consumo sustentáveis; redução dos impactos ambientais; geração de emprego e renda; e educação ambiental.

Conforme consta no documento intitulado Texto Orientador ${ }^{7}$ esses eixos temáticos estão inspirados em dois marcos conceituais em voga no ano de 2013: o Plano Nacional de Resíduos Sólidos e o Plano de Ação para Produção e Consumo Sustentáveis - PPCS, ambos elaborados pelo Ministério do Meio Ambiente.

O Texto Orientador introduz os quatro eixos temáticos nos seguintes termos: “A proposta da 4a CNMA é debater a Política Nacional dos Resíduos Sólidos e a mudança nos padrões de produção e consumo explorando quatro eixos temáticos". (BRASIL, 2013, p. 18)

A ênfase na produção e no consumo, primeiro eixo de discussão, não é exatamente uma novidade, pois o estímulo à adoção de padrões sustentáveis de produção e consumo de bens e serviços consta como um dos objetivos do PNRS, além de ser objeto do PPCS, o qual, já em 2011, postulava sua união com a PNRS.

Podemos relacionar diretamente o eixo de produção e consumo com o quarto eixo, educação ambiental, pois ambos investem em mudanças na sociedade. O que parece plenamente alinhado com o discurso presidencial, que fazia referência à conscientização, a novidade aqui é a ênfase na produção não apenas no consumo. O cerne, no entanto, continua sendo a necessidade de mudança, conscientização - o que será alcançado por meio da educação ambiental - conforme, bem ilustra, o trecho a seguir:

\begin{abstract}
O processo educativo, entendido na perspectiva da interação entre conteúdo e prática, deve estimular cidadania ambiental, qualificando a participação pública nos espaços de consultas/deliberações (fóruns, conselhos, etc) e de gestão ambiental e mobilizando a sociedade sobre a necessidade de uma mudança profunda em toda a cadeia relacionada aos modos de produção e consumo. (BRASIL, 2013, p. 42)
\end{abstract}

O segundo eixo de discussões da IV CNMA, redução de impactos ambientais, finalmente aborda a disposição final adequada dos resíduos. Tal objetivo é, de certa forma, representado pela necessidade de encerrar os lixões, o que deveria ocorrer até 2014.

Atualmente, um dos maiores desafios das administrações municipais é a gestão dos resíduos sólidos e, especialmente após 2010, com a instituição da PNRS, a disposição ambientalmente adequada dos resíduos sólidos passou a ser prioridade para uma parte significativa dos municípios brasileiros, uma vez que os lixões deverão ser eliminados até 2014. (BRASIL, 2013, p. 30) 
O terceiro eixo é a geração de emprego e renda, que se relaciona com os compromissos sociais do governo da época, mantendo assim a coerência com a agenda montada em torno da inclusão social dos catadores de materiais recicláveis, além de reiterar o papel desses atores como protagonistas no alcance das metas do Plano Nacional de Resíduos Sólidos.

\begin{abstract}
Por isso, a coleta seletiva solidária constitui pilar essencial para o desenvolvimento sustentável e representa a alternativa mais limpa, econômica, ambiental e socialmente positiva, quando comparada com as demais opções de gestão de resíduos sólidos urbanos. O sustento de milhares de famílias brasileiras é fruto da atividade quase invisível dos catadores. Eles desempenham um serviço de utilidade pública, pois aliviam os custos de limpeza urbana, aumentam o tempo de vida útil dos aterros sanitários e contribuem para a diminuição das emissões de gases de efeito estufa. Portanto, é necessário que haja mais iniciativas para sensibilizar a sociedade da importância e valor do trabalho desses profissionais. (BRASIL, 2013, p. 37)
\end{abstract}

Esse trecho defende a coleta seletiva solidária ${ }^{8}$ como a opção mais viável para a gestão dos resíduos em função de vantagens sociais e ambientais. Logo em seguida, destaca que a sociedade deve ser sensibilizada a respeito da importância do trabalho dos catadores de materiais recicláveis.

\title{
5.6. PLANO DE RESÍDUOS E MINUTA DA POLÍTICA MUNICIPAL DE GESTÃO INTEGRADA DE RESÍDUOS DE GOIÂNIA
}

A ausência de sustentabilidade financeira do sistema de gestão de resíduos é apontada como uma de suas principais deficiências diagnosticadas pelo plano de resíduos de Goiânia. $\mathrm{O}$ texto do documento resume a questão nos seguintes termos: “Atualmente, não existe sistema de cobrança de taxa de lixo no município: Necessidade de criação e implementação de um sistema financeiramente sustentável”. (GOIÂNIA, 2016, p.225)

Porém, para as três diretrizes relativas aos resíduos sólidos domiciliares secos, foram recomendados ao todo 18 programas e ações. Metade dessas ações refere-se a estratégias de comunicação, conscientização e educação ambiental, e nenhuma diz respeito à sustentabilidade financeira.

Cabe citar ainda, como síntese dos trabalhados da Agência Municipal de Meio Ambiente de Goiânia, a justificativa exposta em uma minuta ${ }^{9}$ de projeto de lei para a Política Municipal de Gestão Integrada de Resíduos, a qual é fruto do contexto de mobilização em torno da elaboração do plano municipal de gestão de resíduos no ano de 2016. 
Conforme é possível verificar no texto abaixo transcrito, na referida justificativa são feitas referências ao excesso de consumo da sociedade, bem como é destacada a falta de educação ambiental como o principal empecilho para implementação da política de resíduos:

Atualmente o problema da geração de resíduos tem se intensificado devido à grande quantidade de produtos consumidos pelas sociedades contemporâneas. Somam-se a isso as dificuldades históricas do poder público em oferecer equipamentos suficientes para os serviços de coleta e destinação de resíduos, e para a correta disposição final dos rejeitos gerados após o consumo dos mais variados produtos. Há ainda, falhas de regulação e fiscalização da destinação de resíduos, ausência de regras e incentivos para os geradores e consumidores realizarem o seu gerenciamento adequado, e principalmente pela ausência de educação ambiental nos níveis formal e não formal de educação.

\subsection{CONSIDERAÇÕES SOBRE OS DOCUMENTOS AVALIADOS}

É possível perceber uma coerência entre o objetivo de formar uma consciência a respeito das problemáticas ambiental e social, conforme expõe a PNEA, e a agenda de governo para os catadores de materiais recicláveis, a qual se apoia justamente na ideia de aliar o combate às desigualdades sociais à defesa do meio ambiente.

Conforme evidenciado, sobremaneira no discurso presidencial, a educação ambiental é compreendida como o instrumento capaz de promover a conscientização necessária para que o trabalho dos catadores seja reconhecido e devidamente valorizado.

Posteriormente, a temática da produção e consumo sustentável foi integrada a esse contexto, o que reforçou ainda mais o protagonismo da educação ambiental, pois mudar os padrões requer a construção de uma nova consciência. O PPCS, por exemplo, propõe ações de educação ambiental direcionadas à população pautadas na coleta seletiva e valorização dos catadores.

Essa conjuntura culminou nos quatro eixos de discussão propostos pela IV CNMA, que compartilham a ideia de combater as desigualdades sociais e promover a gestão adequada dos resíduos apoiando os catadores de materiais recicláveis, o que seria facilitado por meio da educação ambiental, da conscientização. Uma vez que essa consciência seja assimilada pela população, o sistema de gestão de resíduos terá mais chances de funcionar apropriadamente, pois o cidadão consciente deve cumprir com o seu papel - consumir de forma responsável, descartar os resíduos corretamente, reconhecer e apoiar o trabalho dos catadores.

Não há dúvidas de que a participação da população é um fator de sucesso para se alcançar a gestão adequada dos resíduos. Uma participação satisfatória requer educação a respeito de como segregar e 
descartar os resíduos de forma adequada, bem como consciência da importância social dessas ações. Cabe então ao governo, em busca de uma gestão mais eficiente, educar a população e fazer crescer essa consciência, reforçando uma espécie de autorresponsabilização. A educação poderia ser vista assim como uma ponte para criação de novos valores e comportamentos sociais.

Cabe, porém, uma reflexão nesse ponto, pois a baixa adesão ou participação inadequada da população também pode ser explicada pelo contexto precário em termos de infraestrutura, normatização e incentivos, e não apenas pela ausência de consciência. Não seria o caso então de remover barreiras no sentido de facilitar o comportamento correto - prover infraestrutura adequada - antes de culpar moralmente a população pelo insucesso da política pública?

Nesse ponto, revelam-se ao menos duas reflexões importantes. A primeira diz respeito à imputação da responsabilidade pela implementação satisfatória da política em um segmento social - a população. Para que a política tenha sucesso, a população deve ser conscientizada, educada, ajustada. Pois existe um dever, um comportamento ideal para o qual ela supostamente ainda não está preparada. Assim, nota-se claramente a responsabilização da população no campo moral, ou seja, já existe uma obrigação definida socialmente.

Tendo em vista a existência dessa obrigação moral, a educação ambiental surge como o instrumento preferencial para conformação da sociedade a esses valores. Mas o que explica essa preferência diante de outros instrumentos de responsabilização, tais como os de natureza econômica?

Tal qual a moral, a cobrança pela gestão dos resíduos também é uma forma de responsabilizar a população, mas esta reside no campo material, legal. Incentivos econômicos, como descontos, subsídios ou restituições, também são indicados como estímulos à adoção de determinados comportamentos, porém, a priori, não incitam grandes reflexões a respeito do valor moral do comportamento estimulado, apelam basicamente para o proveito econômico.

Esse viés de autointeresse imbuído nos instrumentos econômicos claramente contrapõe-se ao altruísmo do ato consciente de sua relevância social. No primeiro caso, pouco importa a finalidade da ação diante do benefício individual oportunizado; já no segundo caso, eventuais benefícios ou prejuízos individuais são irrelevantes diante do bem maior que o resultado da ação proporciona.

Para o filósofo alemão Immanuel Kant Kant, o valor moral de uma ação não consiste em suas consequências - nos benefícios ou prejuízos resultantes de sua prática -, mas na intenção com a qual 
ação é realizada. O que importa é fazer a coisa certa porque é o certo, e não por algum outro motivo exterior. (SANDEL, 2019)

A moral, portanto, contém uma finalidade em si, não carece de nenhuma motivação externa para que tenha força, basta que seja reconhecida como dever. A conscientização, como discutido até agora, surge como um meio de criar esse dever moral na população, o que em tese exime o Estado de fazer o uso da força para cumprimento da Lei.

Seria um juízo de valor entre a natureza distinta desses dois tipos de instrumentos a origem da preferência pela educação ambiental em detrimento dos instrumentos econômicos?

O segundo aspecto para reflexão trata de um paradoxo referente às responsabilidades do Estado. Ao mesmo tempo em que se reconhecem falhas em termos de atuação do governo - referentes à infraestrutura e normatização -, atribui-se ao Estado o papel de conscientizar a população.

Todavia, se o Estado tem assumidamente enfrentado dificuldades, no cumprimento de suas obrigações mais básicas relativas à construção e manutenção de equipamentos púbicos e à edição de normas, parece um contrassenso atribuir-lhe uma obrigação talvez ainda mais complexa evolvendo a incorporação de valores morais.

Nesse sentido, no âmbito da política de resíduos, a ideia de conscientização parece surgir como uma forma preferencial de atuação do Estado em detrimento da regulamentação e uso da força para fazer cumprir os regulamentos, ou seja, dos mecanismos de comando e controle.

Como destaca a minuta de projeto de lei elaborada pela Agência Municipal de Meio Ambiente de Goiânia, até mesmo a provisão de infraestrutura urbana - locais e equipamentos adequados para descarte dos resíduos, serviços de coleta adequados etc. - ganha pouca relevância diante da necessária conscientização da população.

Por um lado, essa conjuntura pode indicar a preferência pelo instrumento que demanda menos esforço estatal em longo prazo, pois, uma vez que a população cumpre com sua obrigação de forma voluntária, reduz-se a necessidade de intervenção do Estado. Por outro lado, a aposta na conscientização pode revelar uma descrença na capacidade estatal de cumprir com seus deveres básicos em termos de regulamentação, fiscalização e gestão de resíduos.

Cumpre assinalar nesse ponto que os instrumentos econômicos, tais como a taxa pela gestão dos resíduos, oferecem a possibilidade de responsabilizar a população pelo descarte adequado dos resíduos, reduzir a geração, bem como prover recursos para que o Estado possa construir e operar um 
sistema adequado de manejo. Apesar de constar como possibilidade no arcabouço legal vigente, como vimos anteriormente, a discussão em torno desses instrumentos pouco avançou nos últimos anos.

\subsection{NOVA LEGISLATURA, NOVO REFERENCIAL?}

Convém observar possíveis tendências de mudança no referencial preponderante, tendo em vista a mudança de governo em 2019. Nota-se essa inclinação ao examinar o Plano de Ação ${ }^{10}$ do Programa Lixão Zero, divulgado pelo Ministério do Meio Ambiente em maio de 2019. Trata-se de um plano enxuto consignado em sete objetivos:

I. Realizar a destinação final ambientalmente adequada de resíduos sólidos urbanos;

II. Fortalecer a logística reversa;

III. Potencializar a geração de energia a partir dos resíduos sólidos;

IV. Fortalecer a gestão municipal;

V. Fortalecer os consórcios públicos intermunicipais;

VI. Sistematizar informações sobre a gestão dos resíduos sólidos (SINIR);

VII. Elaborar plano nacional de resíduos sólidos. (BRASIL, 2019)

Para alcance desses objetivos o plano sugere uma lista de doze ações, nenhuma delas envolve educação ambiental. O plano também não faz menções aos catadores de materiais recicláveis, configura-se assim uma clara mudança no referencial até então dominante, tendo em vista a exclusão da dimensão social.

Como última referência à mudança de governo, cabe citar ainda o Projeto de Lei 3.261/201911, o qual prevê um incentivo para os municípios que instituírem sistemas de cobrança pela gestão de resíduos. Muito embora o eventual benefício social desse incentivo seja questionável, pois se trata de prorrogar o prazo para que os municípios promovam a destinação adequada dos rejeitos - o encerramento dos lixões.

Conforme texto do Projeto de Lei 3.261/2019 - enviado à Câmara dos Deputados em 12 de junho de 2019 -, os municípios que disponham de mecanismos de cobrança que garantam sua sustentabilidade econômico-financeira, bem como de um plano de resíduos, contarão com um prazo maior para se adequarem à legislação e disporem os rejeitos gerados em seu território de forma adequada. 
A troca de governo pode obviamente representar a formação de um novo referencial, esse certamente não é momento adequado para comprovar essa ocorrência. Cabe, no entanto, atentar para a relevância do discurso de governo na formação do referencial a partir do qual a política é concebida por seus atores-chave. Passados nove anos da edição da PNRS, a dimensão social tão celebrada em seu discurso de promulgação aparentemente perde destaque em função do início de uma nova legislatura.

\section{A PERCEPÇÃO DOS ESPECIALISTAS}

\subsection{METODOLOGIA EMPREGADA}

A fim de confrontar a percepção dos especialistas com os conceitos discutidos no referencial teórico foram realizadas oito entrevistas estruturadas, cujo público-alvo foram atores que estiveram envolvidos com a elaboração do plano de resíduos do Município de Goiânia.

As perguntas foram organizadas de forma a evitar eventuais sugestionamentos. Assim, as questões mais especificas foram dispostas por último, na expectativa de que os entrevistados abordassem os temas centrais para a pesquisa de forma espontânea já nos primeiros tópicos, antes de qualquer eventual referência no enunciado das próprias perguntas.

Uma primeira versão do questionário foi empregada em um teste piloto, realizado com dois especialistas em políticas para gestão de resíduos no mês de junho de 2019. Após avaliação desses resultados, o questionário passou por ajustes que resultaram nas seguintes perguntas:

1. Em sua opinião, quais são os principais objetivos da PNRS?

2. Quais as principais dificuldades para atingir esses objetivos?

3. Que ações você apontaria como prioritárias para o governo atingir os objetivos da PNRS?

4. Como a população pode colaborar para alcançar esses objetivos?

5. Você acredita que as exigências da PNRS estão adequadas às características da população local?

6. Você considera justo premiar o cidadão que descarta seus resíduos de forma adequada ou acredita que este é um dever de todos independente de qualquer recompensa?

7. Em sua opinião, os padrões de produção e consumo dificultam a implementação da política de resíduos? Caso positivo, o que é possível fazer?

8. Você considera justo o governo cobrar da população uma taxa pela gestão dos resíduos? 
9. Você acredita que o governo deve priorizar a atuação dos catadores de materiais recicláveis na implementação das políticas de resíduos? Por quê?

10. Você acredita que medidas como a isenção de impostos de recicladores e a oferta de créditos ou bônus para quem separar e descartar os resíduos adequadamente podem aumentar a reciclagem em nível municipal?

11. No âmbito municipal, que forma de atuação o governo tem priorizado nos últimos anos? (regulamentação, fiscalização, infraestrutura, educação ambiental, participação dos catadores)

12. Você acredita que o governo local possui condições técnicas e materiais para oferecer a infraestrutura adequada e fazer cumprir a PNRS?

13. Em sua opinião, qual a relevância da PNRS para a sociedade?

As entrevistas foram realizadas entre os meses de julho e agosto de 2019. Inicialmente, foram consultados atores-chave na elaboração do plano de resíduos, os quais indicaram outros nomes para colaboração com a pesquisa. No total, foram efetuados dez contatos a partir das indicações de outros especialistas, dos quais dois não tinham disponibilidade ou se recusaram a participar da pesquisa.

Os contatos foram realizados por e-mail e telefone, as entrevistas foram gravadas com auxílio de um telefone celular e depois transcritas para fins de análise. A identidade dos entrevistados foi mantida em sigilo para garantir a espontaneidade dos relatos. Questionou-se aos entrevistados também sobre o tempo de experiência na área, qualificação profissional e se haviam atuado na elaboração do plano de resíduos de Goiânia.

A confiabilidade dos estudos qualitativos requer uma reflexibilidade analítica no sentido de alcançar uma compreensão da estrutura social na qual o tema da pesquisa se insere. Sem essa compreensão, a coleta de dados nas pesquisas qualitativas poder tornar-se inócua, uma vez que, por si só, não permite obter uma visão das dinâmicas sociais por trás de uma determinada realidade. (ULLRICH; OLIVEIRA; BASSO, 2012)

Para consecução da presente pesquisa, além de conhecimento prévio a respeito do tema gestão de resíduos, realizou-se uma imersão prévia em documentos oficiais, planos de resíduos e na própria legislação, o que permitiu elaborar questões pertinentes ao contexto dos atores abordados, bem como uma avaliação contextualizada dos resultados obtidos. 
A escolha dos entrevistados também atende ao requisito da contextualização, uma vez que todos os participantes, além de formação acadêmica, possuíam experiência prática consignada na participação na elaboração do plano de resíduos do Município de Goiânia, a qual envolvia a escolha de diretrizes e instrumentos a serem adotados pelo município.

Após a transcrição, o material obtido foi classificado e agrupado em temas dentro das respostas obtidas para cada pergunta. Em seguida, os temas identificados foram agrupados dentro de categorias, seguindo a metodologia de análise de conteúdo conforme exposto no trabalho de Câmara (2013). Após a categorização, os dados obtidos foram analisados qualitativamente a fim de subsidiar uma discussão a partir das ideias e percepções identificadas.

\subsection{ANÁLISE DO RESULTADO DAS ENTREVISTAS}

\subsubsection{PERFIL DOS ENTREVISTADOS}

Todos os entrevistados possuíam nível superior e títulos de pós-graduação, 75\% são do sexo masculino e $25 \%$ do sexo feminino. Todos participaram diretamente ou acompanharam as discussões para elaboração do plano de resíduos do Município de Goiânia. Demais detalhes estão consignados nos gráficos de 1 a 6 alocados abaixo:

\section{GRÁFICO 1 - TEMPO DE ATUAÇÃO NA ÁREA (ANOS)}

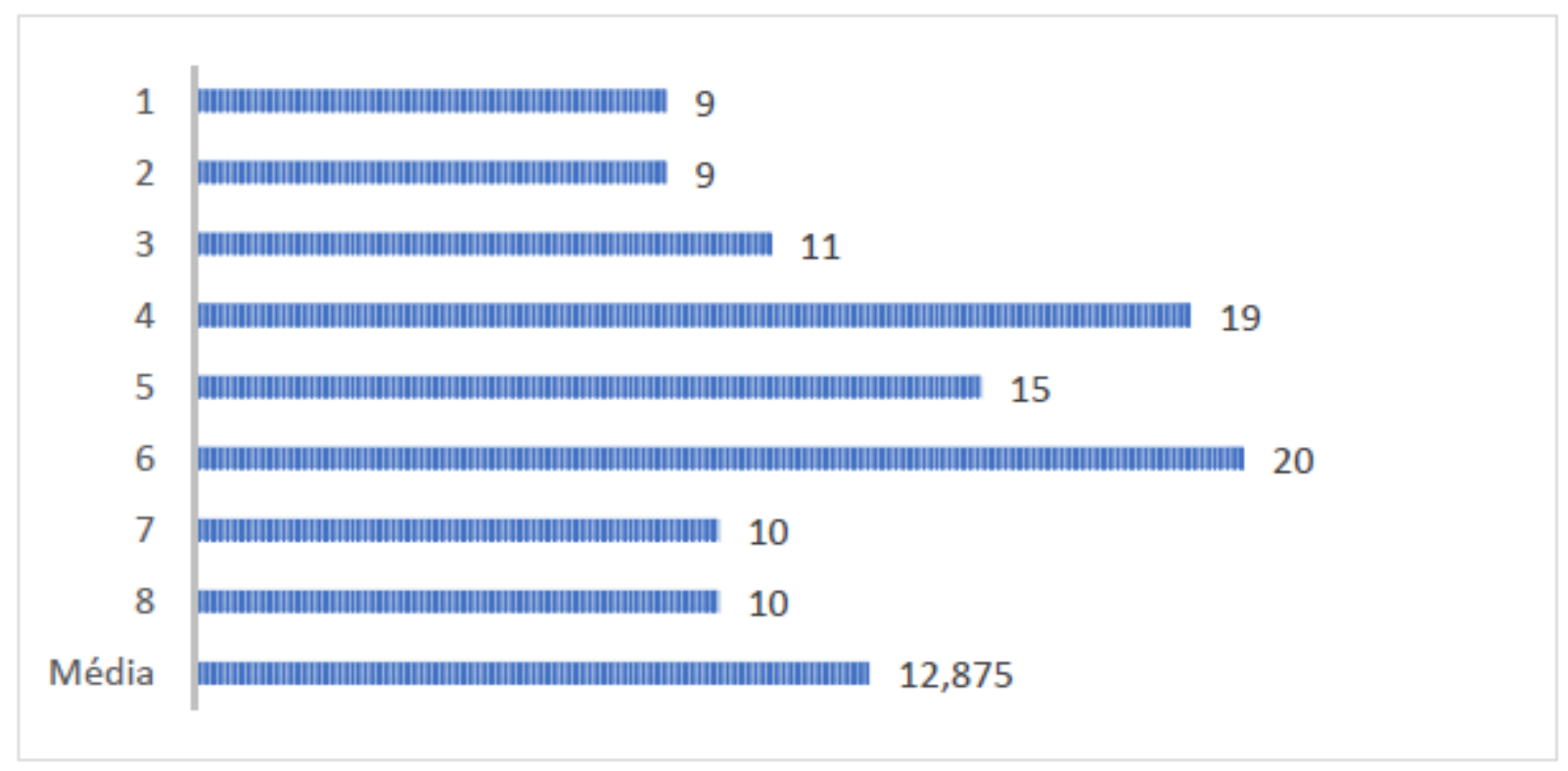




\section{GRÁFICO 2 - FORMAÇÃO ACADÊMICA}

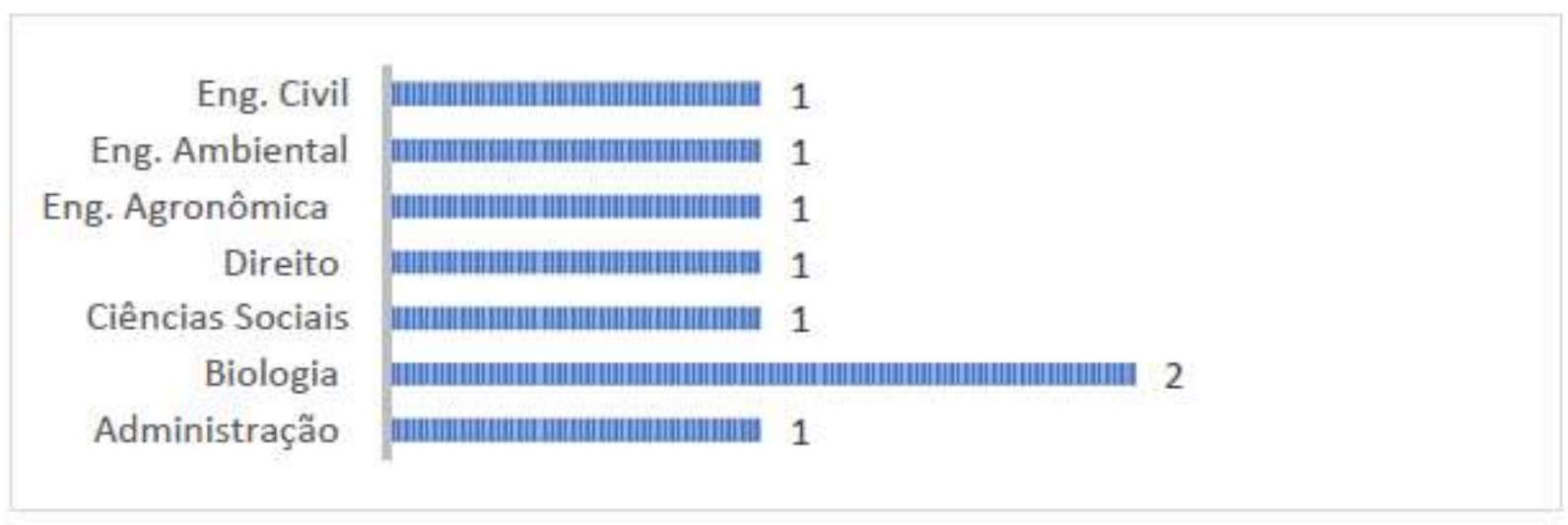

\section{GRÁFICO 3 - PORCENTAGEM DE ENTREVISTADOS COM CURSO DE PÓS-GRADUAÇÃO}

\section{GRÁFICO 4 - SEXO DOS ENTREVISTADOS}

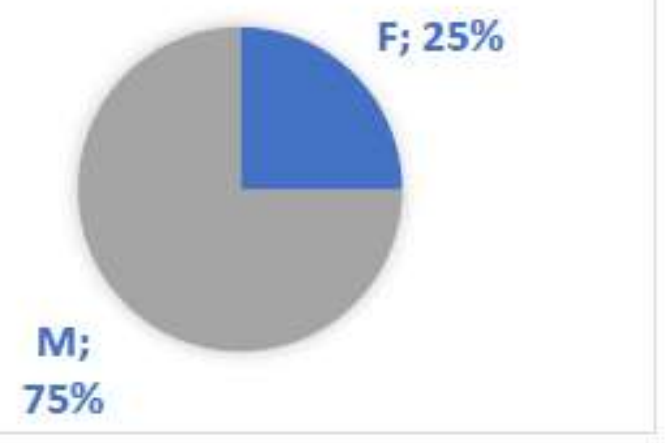

As ideias que compõem o núcleo central para discussão dos resultados despontam logo nas duas primeiras perguntas e guardam semelhança com os eixos de discussão propostos pela IV CNMA. A educação ambiental, os catadores de materiais (eixo geração de emprego e renda) e a redução dos impactos ambientais foram eixos da conferência e surgem como categorias de análise das entrevistas, somam-se a essas categorias os instrumentos econômicos, a logística reversa e questões de governo. 
Na primeira pergunta, ao apontarem quais seriam os principais objetivos da PNRS, os entrevistados manifestaram ideias em torno do tratamento e da hierarquia para a gestão dos resíduos. A relevância da hierarquia, que impõem a rejeição à disposição de resíduos, manifesta-se também no uso de expressões fortes como "erradicar" e "extinguir" os lixões, o que denota ainda preocupação com os impactos ambientais.

Ainda nas repostas à primeira pergunta, o conceito de logística reversa surge integrado ao conceito da responsabilidade compartilhada, exprimindo a ideia de divisão de responsabilidades com outros segmentos da sociedade, tais como a indústria e o comércio, o que desafogaria as prefeituras carentes de estrutura. A educação ambiental aparece como um instrumento-chave por meio do qual a população será conscientizada a respeito da importância ambiental da gestão adequada dos resíduos. O caráter social da PNRS também é lembrado, assim como a necessidade de adoção de incentivos econômicos.

Já na segunda pergunta, quando incitados a falar das dificuldades para alcance dos objetivos da PNRS, os entrevistados ressaltam mais uma vez a educação ambiental e os instrumentos econômicos, além de uma série de questões relativas à capacidade de governo.

O resultado da categorização das verbalizações extraídas das entrevistas pode ser visualizado nos quadros de 01 a 06. 


\section{QUADRO 1 - VERBALIZAÇõES REFERENTES À CATEGORIA INSTRUMENTOS ECONÔMICOS (CONTINUA)}

\begin{tabular}{|c|c|c|c|}
\hline Categoria & $\mathrm{P} / \mathrm{E}$ & Verbalizações & $\mathrm{N}^{\circ}$ \\
\hline \multirow{12}{*}{ 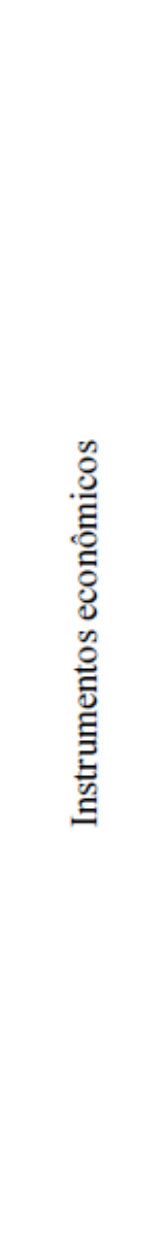 } & $1 / 4$ & [...] eu vou incentivar, seja por redução fiscal, redução de tributos e impostos $[\ldots]$ & 1 \\
\hline & $1 / 5$ & $\begin{array}{l}\text { [...] os governos desoneram muitas indústrias em várias áreas, mas não desonera a parte da reciclagem, que eu acho que seria } \\
\text { superinteressante. }\end{array}$ & 2 \\
\hline & $2 / 4$ & {$[\ldots]$ a política precisa realmente estabelecer linhas de financiamento pra poder viabilizar essa vontade de fazer $[\ldots]$} & 3 \\
\hline & $2 / 5$ & $\begin{array}{l}{[\ldots] \text { inclusive até de cobrança da geração de resíduos, eu sempre defendi essa parte né, porque a partir do momento que você onera }} \\
\text { e corresponsabiliza financeiramente as pessoas pelos gastos que você vai ter com resíduos, você já coloca um empecilho pra pessoas } \\
\text { gerarem [...] }\end{array}$ & 4 \\
\hline & $2 / 8$ & {$[\ldots]$ pra fechar a cadeia produtiva você precisa atrair as empresas de reciclagem $[\ldots]$} & 5 \\
\hline & $3 / 1$ & {$[. .$.$] se não tiver um reordenamento [. .$.$] principalmente da parte fiscal, os municípios vão ficar sendo penalizados.$} & 6 \\
\hline & $3 / 3$ & [...] a pessoa começa com um pequeno incentivo financeiro e pega o hábito de fazer. & 7 \\
\hline & $3 / 3$ & $\begin{array}{l}{[\ldots] \text { sei lá, um ICMS verde pra ajudar indústrias a se instalarem no Estado porque não adianta a gente fazer a coleta seletiva certinha }} \\
\text { e não ter pra quem vender }[\ldots]\end{array}$ & 8 \\
\hline & $3 / 5$ & $\begin{array}{l}{[\ldots] \text { se tivessem fontes de recurso que pudessem alimentar essa pequena indústria, você com certeza teria um potencial de reciclagem }} \\
\text { muito maior e daí desafogaríamos os aterros sanitários }[\ldots]\end{array}$ & 9 \\
\hline & $4 / 8$ & $\begin{array}{l}{[\ldots] \text { a questão da cobrança pelo serviço é um instrumento econômico que também vai ajudar nessa formação, não no sentido de }} \\
\text { punir }[\ldots]\end{array}$ & 10 \\
\hline & $4 / 8$ & [...] então sei lá, às vezes criar alguns incentivos: quem separar não pagar, quem não separar pagar [...] & 11 \\
\hline & $5 / 2$ & $\begin{array}{l}{[\ldots] \text { eu acho que tem que caminhar pruma taxa do lixo, por mais que seja uma medida impopular }[\ldots] \text { a gente vai precisar discutir }} \\
\text { muito com a sociedade pra gente conseguir criar uma coisa que é boa pra todo mundo. }\end{array}$ & 12 \\
\hline
\end{tabular}




\begin{tabular}{|c|c|c|}
\hline $5 / 3$ & $\begin{array}{l}\text { [...] uma outra forma também é você de fato exigir o estado e o Governo Federal, que os municípios obriguem. a dispor a coleta } \\
\text { seletiva e alguns serviços públicos, ainda que tenha que cobrar, seja a taxa do lixo, seja as taxas de compra da embalagem [...] }\end{array}$ & 13 \\
\hline $5 / 5$ & $\begin{array}{l}{[\ldots] \text { então eu sou a favor da cobrança sim e que ela tenha, ela não pode ser igual também para todos os bairros, ela tem que trabalhar }} \\
\text { por bairros, por quadras [...] }\end{array}$ & 14 \\
\hline $6 / 1$ & {$[\ldots]$ Não vejo como obrigação não, eu acho que o cara tem que ser premiado sim, tem que ter planos de incentivo [...] } & 15 \\
\hline $6 / 2$ & [...] é a questão do poluidor pagador e do poupador recebedor, então eu entendo que mais que punir é dar incentivos. & 16 \\
\hline $6 / 2$ & $\begin{array}{l}{[\ldots] \text { Acho que tem que ser premiado. Acho sim }[\ldots] \text { caso venha a instituir uma taxa ou tarifa do lixo, que ela venha com [...] benefícios }} \\
\text { pra quem participa de alguma ação }[\ldots]\end{array}$ & 17 \\
\hline $6 / 3$ & $\begin{array}{l}{[\ldots] \mathrm{Eu} \text { acho que isso é uma obrigação, não acho que o morador tem que ser beneficiado com isso não, eu acho que isso é uma }} \\
\text { obrigação [...] passou da hora na minha opinião de Goiânia ter cobrança da taxa de lixo, essa é a minha opinião e não vejo por que } \\
\text { não. }\end{array}$ & 18 \\
\hline $6 / 4$ & $\begin{array}{l}\text { [...] não é justo aí, por exemplo, você instituir uma taxa de coleta de lixo na cidade e aquela pessoa que já faz a coleta seletiva, ele } \\
\text { já reduz, ela já recicla, ele já ajuda, já colabora, e a coleta às vezes pega menos do que uma pessoa que não faz, ele vai pagar o } \\
\text { mesmo tanto? }\end{array}$ & 19 \\
\hline $6 / 5$ & [...] eu acho que é uma obrigação dele, mas acho justo, por exemplo, se ele separa ele pode diminuir a taxa que ele paga [...] & 20 \\
\hline $6 / 6$ & $\begin{array}{l}{[\ldots] \text { acho que a gente tem que premiar não, mas acho que a gente tem que incentivar empresas a começar esse tipo de trabalho, }} \\
\text { tirando isenção de ICMS, de COFINS, sei lá [...] }\end{array}$ & 21 \\
\hline $6 / 7$ & $\begin{array}{l}\text { [...] Eu acho super justo, parabenizar, premiar o cidadão que tem um...que se envolve, que participa do gerenciamento adequado } \\
\text { dos seus resíduos, assim como eu sou a favor de um preço maior pra os que não se envolvem, é o princípio do poluidor pagador e } \\
\text { do protetor recebedor [...] }\end{array}$ & 22 \\
\hline $7 / 4$ & $\begin{array}{l}{[\ldots] \text { nós precisamos começar a mudar esse padrão de consumo, então cobrar mais caro para quem consome mais, cobrar de quem }} \\
\text { gera lixo e cobrar mais caro de quem gera mais, e bonificar quem gera menos pra gente mudar essa rota. }\end{array}$ & 23 \\
\hline
\end{tabular}




\begin{tabular}{|c|c|c|}
\hline $8 / 1$ & $\begin{array}{l}{[\ldots] \text { totalmente a favor, e digo mais, eu acho cobrança errada, eu acho que a cobrança tinha que ter mecanismo de grandes geradores }} \\
\text { serem mais penalizados [...] }\end{array}$ & 24 \\
\hline $8 / 2$ & $\begin{array}{l}{[\ldots] \text { Acho justo, acho justo, porque, como eu te falei, é um gasto muito grande. [...] penso a taxa vinculada a um incentivo, como eu }} \\
\text { tinha falado né, não vir só a taxa, não vir uma coisa só punitiva. }\end{array}$ & 25 \\
\hline $8 / 3$ & $\begin{array}{l}{[\ldots] \text { se você cobra por isso, a própria população vai se atentar mais para a questão do lixo, e consequentemente ela vai tentar gerar }} \\
\text { menos lixo, então é uma educação ao contrário, ela vem pelo contrário, eu vou diminuir o que eu tô gerando para pagar menos, e } \\
\text { de todas as maneiras isso é bom. }\end{array}$ & 26 \\
\hline $8 / 4$ & $\begin{array}{l}{[\ldots] \text { se o governo trouxer uma taxa, que ele diferencie o grande do pequeno e diferencie aquele que faz coleta seletiva, aquele que }} \\
\text { gera menos dos demais eu acho positivo [...] }\end{array}$ & 27 \\
\hline $8 / 5$ & $\begin{array}{l}{[\ldots] \text { Eu não acho justo não, porque a gente já paga imposto demais e esse dinheiro, se esse dinheiro dos impostos todo que a gente }} \\
\text { paga fosse destinado aos lugares corretos, a gente não precisava ter mais uma taxa, mas eu não vejo como evitar que ela seja } \\
\text { realmente instituída [...] }\end{array}$ & 28 \\
\hline $8 / 7$ & $\begin{array}{l}\text { [...] cobrar é importante pra sustentabilidade do sistema, porque não é barato implantar e também não é barato manter um sistema } \\
\text { de gestão integrado funcionando adequadamente, por outro lado também, cobrar pela geração quer dizer, quanto mais se gera mais } \\
\text { se cobra, é uma maneira extremamente pedagógica de estimular com que o resíduo seja segregado e destinado gratuitamente para a } \\
\text { coleta seletiva porque eu já diminuo meu volume então eu vou pagar menos [...] }\end{array}$ & 29 \\
\hline $10 / 1$ & $\begin{array}{l}\text { Tem que acontecer ontem. Tem que ter incentivo. Porque que o cara que vende o plástico in natura tem que pagar quase o mesmo } \\
\text { preço que o cara que vende o plástico reciclado }[\ldots]\end{array}$ & 30 \\
\hline $10 / 2$ & $\begin{array}{l}\text { Tenho certeza [...] eu acho que quanto mais incentivos a gente tiver, melhor, porque hoje a gente tem uma taxa de recuperação de } \\
\text { recicláveis de } 4 \%[. . .] \text {, então qualquer incentivo que a gente fizer pra aumentar a porcentagem de recicláveis não é um gasto e sim } \\
\text { um investimento. }\end{array}$ & 31 \\
\hline
\end{tabular}




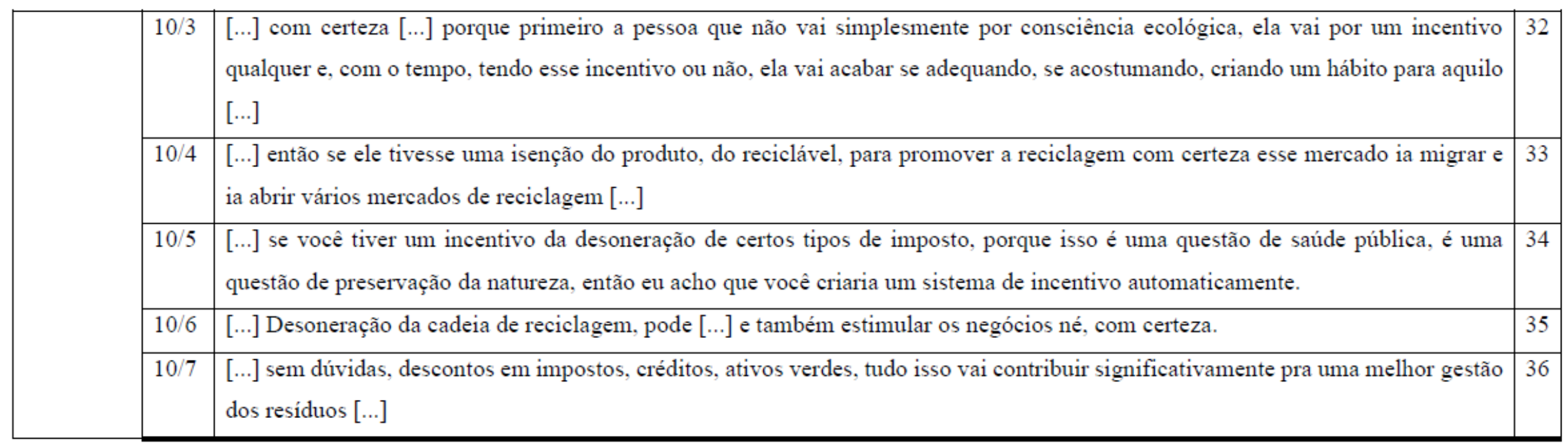

\section{QUADRO 2 - VERBALIZAÇÕES REFERENTES À CATEGORIA EDUCAÇÃo AMBIENTAL}

\begin{tabular}{|c|c|c|c|}
\hline Categoria & $\mathrm{P} / \mathrm{E}$ & Verbalizações & $\mathrm{N}^{\circ}$ \\
\hline \multirow{5}{*}{ 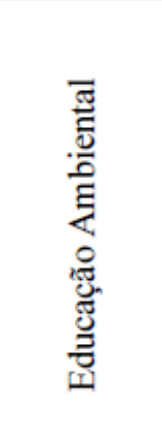 } & $1 / 4$ & {$[. .$.$] pra não gerar você tem que fazer toda uma política, né, de repensar, de educar a população [\ldots]$} & 1 \\
\hline & $1 / 5$ & {$[\ldots]$ nós vamos colocar na cabeça das pessoas a necessidade da preservação do meio ambiente $[. .]$.} & 2 \\
\hline & $2 / 3$ & [...] falta também muito fortemente a participação da população, se a população não se envolver é muito complicado [...] & 3 \\
\hline & $2 / 4$ & [...] então primeiro é despertar essa consciência $[\ldots]$ & 4 \\
\hline & $3 / 3$ & $\begin{array}{l}\text { Educação ambiental de uma maneira geral, campanha em televisão, campanha em rádio, panfletos, envolvimentos em escolas, } \\
\text { porque se você educa a criança ela cresce com isso, educação ambiental a partir da base, porque quando você educa a criança, você } \\
\text { cria um hábito [...] }\end{array}$ & 5 \\
\hline
\end{tabular}




\begin{tabular}{|c|c|c|}
\hline $4 / 1$ & $\begin{array}{l}{[\ldots] \text { essa conscientização ambiental, porque se você retrocede, igual já aconteceu várias vezes aqui em Aparecida e Goiânia, a }} \\
\text { população desacredita e o projeto vai por água abaixo [...] }\end{array}$ & 6 \\
\hline $4 / 2$ & $\begin{array}{l}\text { A população é a mais importante aí nesse processo [...] o que a gente precisa [...] é dar maior publicidade, maior divulgação, maior } \\
\text { informação à sociedade [...] a gente precisa investir mais nessa forma de informação mesmo, informar a população pra que eles } \\
\text { saibam que eles são importantes, eles estão com esse papel e eles têm uma obrigação dentro desse processo. }\end{array}$ & 7 \\
\hline $4 / 3$ & {$[\ldots]$ a população tem que se conscientizar primeiro $[\ldots]$, a população tem que aprender a separar $[\ldots]$} & 8 \\
\hline $4 / 4$ & $\begin{array}{l}\text { [...] eu acho que a população, primeiro ela pode saber, pode ajudar primeira sabendo o que é essa política, que implicações traz pra } \\
\text { mim, que ganhos, que obrigações e procurar ajudar [...], o primeiro é saber como ajudar [...] }\end{array}$ & 9 \\
\hline $4 / 5$ & {$[\ldots]$ uma campanha massiva de educação ambiental, seja nas escolas [...] } & 10 \\
\hline $4 / 6$ & {$[\ldots]$ infelizmente a sociedade não tem essa consciência, é uma parcela ínfima da sociedade que faz essa separação em casa [...] } & \\
\hline $4 / 7$ & $\begin{array}{l}\text { [...] não é só compreender como que se faz uma coleta seletiva ou qual que é a importância de eu fazer a destinação do meu resíduo } \\
\text { pra um ecoponto, é mais do que isso, é se tornar participe da política pública a ponto de fiscalizar, a ponto de orientar, porque é uma } \\
\text { transformação cultural, e a transformação cultural não por meio só das ações do governo. É uma transformação que acontece no } \\
\text { seio da sociedade e pra isso acontecer precisa haver sentido, envolvimento, eles precisam entender como a coisa é importante e } \\
\text { obviamente [...] }\end{array}$ & 11 \\
\hline $4 / 8$ & [...] eu vejo o seguinte, a população culturalmente ela se mobiliza muito fácil [...] & \\
\hline $5 / 3$ & $\begin{array}{l}{[\ldots] \text { eu acho que o que tá faltando ali um pouco é a questão de educar um pouco a população. A população tem que ser um pouco }} \\
\text { mais bem educada [...] }\end{array}$ & 12 \\
\hline $5 / 4$ & {$[\ldots]$ é preciso adequar por meio de instrumento de educação ambiental e de informação $[. .]$.} & 13 \\
\hline $7 / 2$ & $\begin{array}{l}{[\ldots] \text { o que a gente tem que priorizar é a educação ambiental, pra que as pessoas tomem consciência daquilo que elas estão }} \\
\text { consumindo e daquilo que elas estão gerando [...] }\end{array}$ & 14 \\
\hline $7 / 3$ & [...] sem envolvimento de escolas não vai pra frente, porque a criança tem que ser educada em casa e reforçado na escola [...] & 15 \\
\hline
\end{tabular}




\begin{tabular}{|l|l|l|l|}
\hline & $7 / 6$ & $\begin{array}{l}{[\ldots] \text { a gente tem mais uma vez que pensar é na questão da conscientização, porque a indústria só vai diminuir produção a partir do }} \\
\text { momento em que o consumo diminuir }[\ldots]\end{array}$ & 16 \\
\cline { 2 - 5 } & $7 / 7$ & $\begin{array}{l}{[\ldots] \text { as pessoas precisando compreender da importância de se reutilizar, de reaproveitar, esses materiais, esses resíduos pra que a }} \\
\text { gente não continue descartando muito e consumindo matérias-primas que são cada vez mais escassas. }\end{array}$ & 17 \\
\cline { 2 - 5 } & $12 / 5$ & {$[\ldots]$ isso depende do poder público, da conscientização sim, como é que você conscientiza a população? } & 18 \\
\hline $13 / 4$ & {$[\ldots]$ então eu acho que é relevante uma política pra que essa população saiba, se conscientize, toma um rumo, saia do lugar [...] } & 19 \\
\cline { 2 - 4 } & $13 / 5$ & {$[\ldots]$ pra você realmente implementar essas políticas, é trabalhar massivamente com educação ambiental $[\ldots]$} & 20 \\
\cline { 2 - 4 } & $13 / 6$ & {$[\ldots]$ A sociedade, na minha opinião, ela não tem conhecimento dessa legislação, ela não conhece $[\ldots]$} & 21 \\
\hline
\end{tabular}

\section{QUADRO 3 - VERBALIZAÇÕES REFERENTES À CATEGORIA QUESTÕES DE GOVERNO}

\begin{tabular}{|c|c|c|c|}
\hline Categoria & $\mathrm{P} / \mathrm{E}$ & Verbalizações & $\mathrm{N}^{\circ}$ \\
\hline \multirow{6}{*}{ 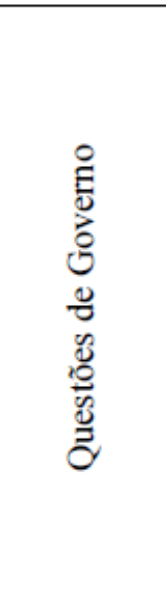 } & $2 / 1$ & [...] vontade política e orçamento para área [...] & 1 \\
\hline & $2 / 2$ & $\begin{array}{l}\text { [...] É a questão da descontinuidade política, eu acho que é um dos maiores entraves pra efetivação da política nacional de resíduos } \\
\text { sólidos. }\end{array}$ & 2 \\
\hline & $2 / 4$ & {$[\ldots]$ acho que primeiro é vontade $[\ldots]$} & 3 \\
\hline & $2 / 4$ & $\begin{array}{l}{[\ldots] \text { técnicos, a gente precisa de pessoal qualificado, não é porque a gente trabalha com lixo que todo mundo acha que entende, tem }} \\
\text { que ter conhecimento técnico, científico qualificado e competência pra fazer isso [...] }\end{array}$ & 4 \\
\hline & $2 / 6$ & $\begin{array}{l}\text { [...] alguém tem que ser o ator principal, alguém tem que puxar isso, e eu acho que quem tem que realmente iniciar né, dar o start, } \\
\text { começar o início disso, tem que ser o Estado [...] }\end{array}$ & 5 \\
\hline & $3 / 4$ & [...] primeiro eu acho que é atualização dos instrumentos de planejamento [...] & 6 \\
\hline
\end{tabular}




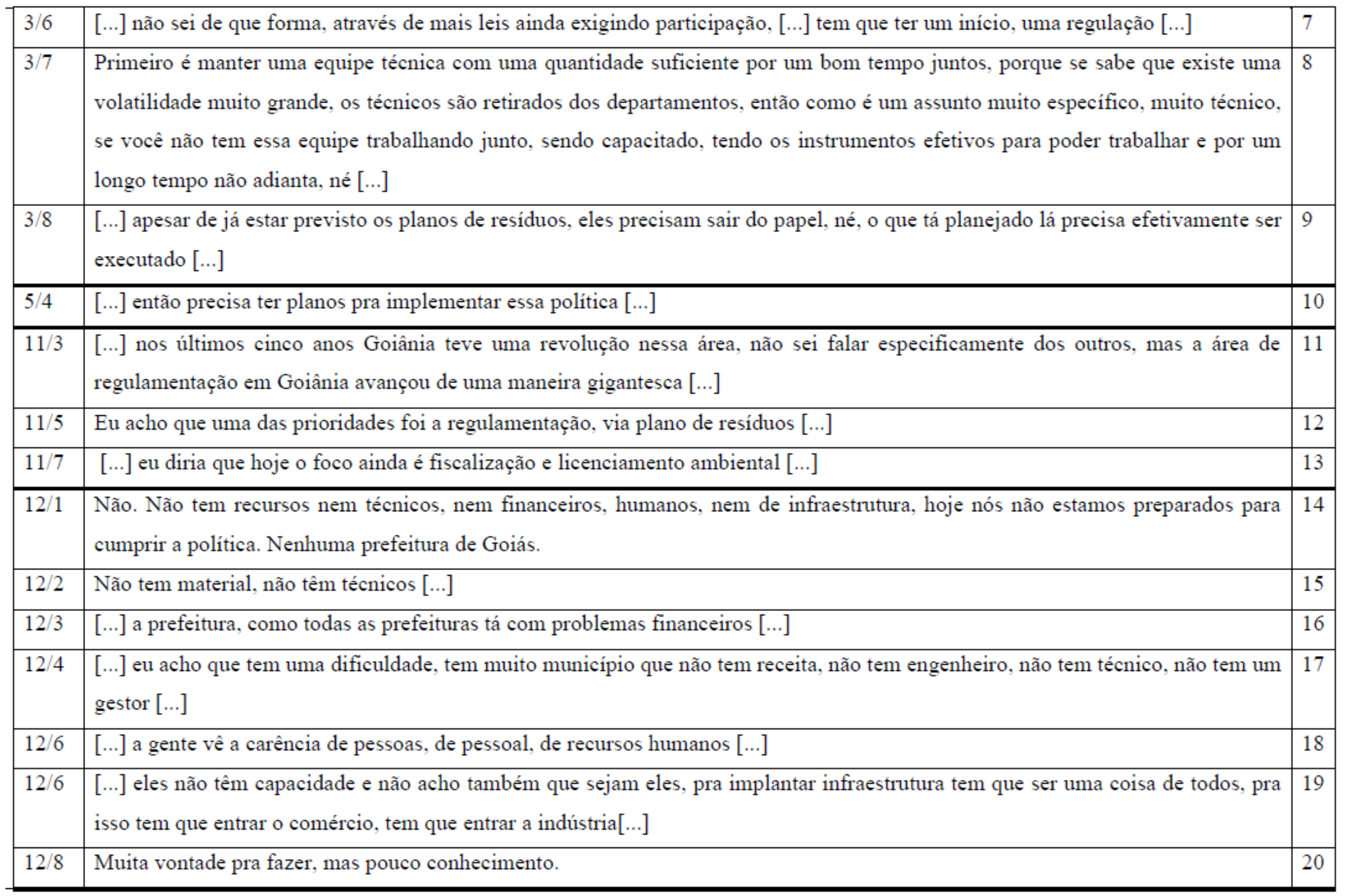




\section{QUADRO 4 - VERBALIZAÇÕES REFERENTES À CATEGORIA LOGÍSTICA REVERSA}

\begin{tabular}{|c|c|c|c|}
\hline Categoria & $\mathrm{P} / \mathrm{E}$ & Verbalizações & $\mathrm{N}^{\circ}$ \\
\hline \multirow{11}{*}{ 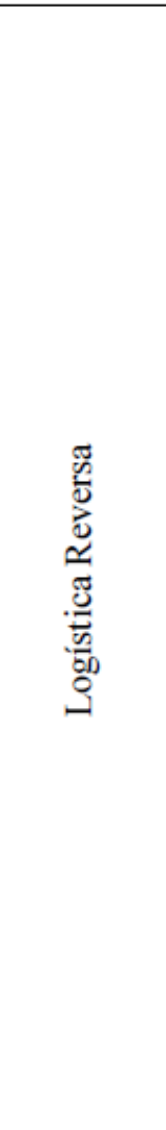 } & $1 / 2$ & $\begin{array}{l}\text { [...] o termo da política nacional, da responsabilidade compartilhada, eu acho um dos mais importantes, né, porque responsabiliza } \\
\text { toda a cadeia não só a prefeitura, né }[\ldots]\end{array}$ & 1 \\
\hline & $1 / 3$ & $\begin{array}{l}{[\ldots] \text { a questão da logística reversa como um todo, que é realmente acionar toda a cadeia, a indústria, o distribuidor e consumidor }} \\
{[\ldots]}\end{array}$ & 2 \\
\hline & $1 / 5$ & {$[\ldots]$ então e a discussão mais efetiva acho que tá faltando pra nós, é da logística reversa $[. .]$.} & 3 \\
\hline & $1 / 6$ & [...] Eu acho que a logística reversa é o ideal pra gente chegar em uma situação ótima de questão de resíduos [...] & 4 \\
\hline & $2 / 8$ & {$[\ldots]$ você tem que discutir a questão da logística reversa $[\ldots]$} & 5 \\
\hline & $3 / 3$ & $\begin{array}{l}{[\ldots] \text { se o governo exigir que as indústrias de vidro recolham seus vasilhames, recolham suas embalagens, eles vão ter que provar }} \\
\text { isso, eles mesmo vão ajudar [...] }\end{array}$ & 6 \\
\hline & $3 / 3$ & {$[\ldots]$ a outra questão é o governo de fato começar a ser mais radical, por exemplo, na logística reversa $[\ldots]$} & 7 \\
\hline & $5 / 6$ & {$[. .$.$] tão trazendo, por exemplo, logística reversa de embalagens de medicamentos, que não era obrigatório [...]$} & 8 \\
\hline & $7 / 1$ & $\begin{array}{l}\text { [...] muito, muito, atrapalha, com certeza, e tanto que todas aquelas metas que deveriam sair lá em 2013, } 14 \text {, para os setores de } \\
\text { embalagens, o negócio foi...né? O governo não teve pulso firme de passar responsabilidade. }\end{array}$ & 9 \\
\hline & $7 / 2$ & $\begin{array}{l}\text { [...] Agora o consumidor, ele precisa saber o seu papel nesse processo todo [...]. Falo inclusive na questão da logística reversa que } \\
\text { tá sendo tão complicada. }\end{array}$ & 10 \\
\hline & $7 / 3$ & $\begin{array}{l}\text { [...] daí a importância da questão dos acordos setoriais, se o governo começar a cobrar da indústria, a indústria vai fazer suas próprias } \\
\text { campanhas e com isso incentiva a população. }\end{array}$ & 11 \\
\hline
\end{tabular}




\begin{tabular}{|l|l|l|}
\hline $7 / 5$ & $\begin{array}{l}{[\ldots] \text { nós produzimos cada vez mais descartáveis, nós estamos em uma sociedade que o consumo de descartáveis é muito grande e o }} \\
\text { descarte desses descartáveis não tem nenhuma política mais assumida pela população, de que eles podem ou não podem ser } \\
\text { reciclados, ou entrar no ciclo da logística reversa }[\ldots]\end{array}$ & 12 \\
\hline $8 / 5$ & $\begin{array}{l}{[\ldots] \text { Considero, porque aí vai haver uma pressão de baixo pra cima para a indústria, por exemplo, a indústria ao gerar alguma coisa }} \\
\text { que é reciclável ela já vai embutir no valor daquele produto a devolução dele. Ao devolver uma televisão que já não se usa mais, } \\
\text { ele recebe um bônus por aquilo, e assim outros produtos também. }\end{array}$ & 13 \\
\hline $11 / 8$ & {$[\ldots]$ a parte de logística reversa já começamos a discutir alguns pontos, não avançou ainda até mesmo por falta de conhecimento $[\ldots]$} & 14 \\
\hline $12 / 4$ & {$[\ldots]$ acredito que se o município não tiver estrutura, mas tiver vontade, ele pode organizar com a iniciativa privada [...] } & 15 \\
\hline $12 / 6$ & $\begin{array}{l}{[\ldots] \text { não acho também que sejam eles pra implantar infraestrutura, tem que ser uma coisa de todos, pra isso tem que entrar o comércio, }} \\
\text { tem que entrar a indústria, pra poder ajudar nessa questão da infraestrutura. Todos aqueles que estão envolvidos na cadeia }[\ldots]\end{array}$ & 16 \\
\hline
\end{tabular}

\section{QUADRO 5 - VERBALIZAÇÕES REFERENTES À CATEGORIA CATADORES}

\begin{tabular}{|c|c|c|c|}
\hline Categoria & $\mathrm{P} / \mathrm{E}$ & Verbalizações & $\mathrm{N}^{\circ}$ \\
\hline \multirow{4}{*}{ 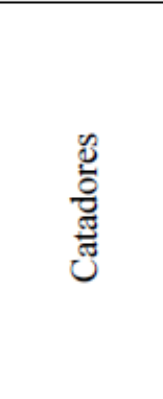 } & $1 / 2$ & {$[\ldots]$ eu acho que é uma coisa importante que é esse trabalho social que a política traz $[. .]$.} & 1 \\
\hline & $2 / 8$ & $\begin{array}{l}{[\ldots] \text { tá previsto até na própria legislação, eu tenho um trabalho muito grande aqui com a coleta seletiva e as cooperativas de catadores, }} \\
\text { mas eu falo sempre pra eles que o objetivo não são eles [...] }\end{array}$ & 2 \\
\hline & $3 / 5$ & [...] sempre defendi a criação de cooperativas, sou um defensor árduo de cooperativas [...] & 3 \\
\hline & $4 / 5$ & $\begin{array}{l}{[\ldots] \text { remunerar ou fazer uma política pública de remuneração das cooperativas que trabalharem efetivamente com a coleta seletiva }} \\
{[\ldots]}\end{array}$ & 4 \\
\hline
\end{tabular}




\begin{tabular}{|c|c|c|}
\hline $9 / 1$ & $\begin{array}{l}{[\ldots] \text { a questão da inclusão dos catadores a gente não pode esconder, é uma realidade. Tem que incluir? Tem que ter uma política de }} \\
\text { inclusão, do jeito que está sendo feita não sei se é o ideal [...] }\end{array}$ & 5 \\
\hline $9 / 2$ & $\begin{array}{l}\text { [...] Com certeza, a própria política nacional fala que os resíduos têm que ser encaminhados prioritariamente para as cooperativas } \\
{[\ldots] \text {. Penso que o trabalho que eles fazem de separação dos resíduos é um trabalho muito insalubre, é um trabalho que ele tem que }} \\
\text { acabar [...], elas só vão conseguir crescer de fato se elas forem contratadas pela prefeitura porque hoje o que a prefeitura faz é pegar } \\
\text { o resíduo da casa das pessoas, entregar para cooperativa, a cooperativa separa e vende [...]. Eles conseguem sobreviver com a venda } \\
\text { desses materiais, sendo que o trabalho que eles estão fazendo é de desviar resíduos do aterro sanitário, o trabalho que eles estão } \\
\text { fazendo é de limpeza pública, como a SLU, como o sistema de limpeza pública [...] }\end{array}$ & 6 \\
\hline $9 / 3$ & $\begin{array}{l}\text { [...] Sim. Já existe, né? Tem uma lei específica que fala... se o governo deve ajudar? O governo já tá fazendo a parte dele [...], acaba } \\
\text { que lá na ponta quem separa o material é eles mesmo. Então eu acho que as cooperativas tem que ser mais valorizadas, elas não } \\
\text { devem ser encaradas somente como instituições parceiras, não só, elas são mais que isso, elas são prestadoras de serviço para a } \\
\text { prefeitura como um todo [...] }\end{array}$ & 7 \\
\hline $9 / 3$ & $\begin{array}{l}\text { [...] primeiro eles precisam de uma ajuda como ser humano, pra poder depois passar por essa questão do emprego, então é uma } \\
\text { questão de emprego e renda, tem que ter mesmo. }\end{array}$ & 8 \\
\hline $9 / 4$ & $\begin{array}{l}{[\ldots] \text { os catadores, eles são o elo entre a população e a reciclagem }[\ldots] \text {, elas prestam um serviço ambiental e esse serviço precisa ser }} \\
\text { remunerado }[\ldots]\end{array}$ & 9 \\
\hline $9 / 4$ & $\begin{array}{l}\text { [...] eles precisam ser assistidos pelo governo e ao mesmo tempo, além da parte social, ele também é importante pra economia e } \\
\text { deve ser valorizado. }\end{array}$ & 10 \\
\hline $9 / 5$ & $\begin{array}{l}{[\ldots] \text {, mas a parte da prefeitura ela tinha que remunerar esse pessoal, por quê? Por que senão eles ficam como? Eles ficam como }} \\
\text { simplesmente funcionais ao sistema da questão dos resíduos da cidade, mas nem por isso ganham [...] }\end{array}$ & 11 \\
\hline $9 / 6$ & $\begin{array}{l}\text { [...] a própria política fala que eles têm que ser inseridos, né, eu não acredito que dessa forma, com o tipo de cooperativa que a gente } \\
\text { tem hoje, a gente consiga realmente implementar uma logística reversa, porque para ela ser feita tem que virar realmente um negócio } \\
{[\ldots]}\end{array}$ & 12 \\
\hline
\end{tabular}




\begin{tabular}{|c|c|c|}
\hline $9 / 7$ & $\begin{array}{l}{[\ldots] \text { eu acho fundamental, primeiro porque a PNRS já define isso, e segundo porque a gente sabe que é uma realidade de países }} \\
\text { como Brasil em que a atividade de coleta se torna uma fonte de renda e essas e que essas pessoas estão vulneráveis socialmente, } \\
\text { economicamente }[\ldots]\end{array}$ & 13 \\
\hline $11 / 2$ & {$[\ldots]$ desenvolveu um pouco da parte de infraestrutura $[\ldots]$ teve aí a construção de três novos galpões para as cooperativas $[\ldots]$} & 14 \\
\hline $11 / 4$ & {$[\ldots]$ Goiânia tem privilegiado, né, o trabalho com os catadores [...] } & 15 \\
\hline $11 / 6$ & [...] eles têm incentivado as cooperativas [...] & 16 \\
\hline
\end{tabular}

QUADRO 6 - VERBALIZAÇÕES REFERENTES À CATEGORIA IMPACTOS AMBIENTAIS

\begin{tabular}{|c|c|c|c|}
\hline Categoria & $\mathrm{P} / \mathrm{E}$ & Verbalizações & $\mathrm{N}^{\circ}$ \\
\hline \multirow{8}{*}{ 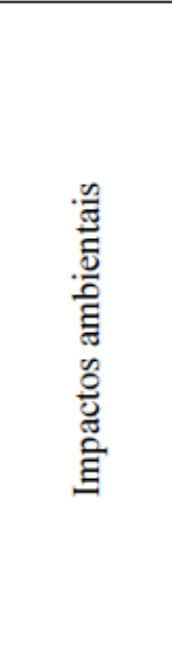 } & $1 / 1$ & Eu acho que o principal objetivo da Política, inicial, deveria ser o correto tratamento do resíduo. & 1 \\
\hline & $1 / 2$ & [...] o principal objetivo da política nacional que eu vejo é a extinção dos lixões. & 2 \\
\hline & $1 / 3$ & {$[\ldots]$ o principal realmente era erradicar os lixões no país $[\ldots]$} & 3 \\
\hline & $1 / 4$ & {$[\ldots]$ promover a gestão integrada dos resíduos dentro de uma hierarquia de prioridades $[\ldots]$} & 4 \\
\hline & $1 / 8$ & $\begin{array}{l}\text { Prevenir resíduos, né }[\ldots] \text {, não tem a hierarquização de resíduos do art. 9? Tem que seguir aquilo lá, aquilo ali não é uma pretensão } \\
\text { ou programa, é uma obrigação [...] }\end{array}$ & 5 \\
\hline & $13 / 1$ & $\begin{array}{l}\text { [...] destinação inadequada de resíduos pode causar doenças, contaminações, poluição de corpos hídricos, solo, emissões } \\
\text { atmosféricas, etc. }\end{array}$ & 6 \\
\hline & $13 / 2$ & [...] todo dia a gente vê problema de descarte de resíduo em local inadequado, em área de APP, aterrando corpo hídrico [...] & 7 \\
\hline & $13 / 8$ & [...] quanto mais tempo eu mantiver essa matéria-prima em circulação, mas bem ambiental eu faço $[. .]$. & 8 \\
\hline
\end{tabular}




\subsubsection{INSTRUMENTOS ECONÔMICOS}

Dentro da categoria de instrumentos econômicos foram identificados três eixos temáticos para discussão: incentivos, cobrança pela gestão dos resíduos e financiamento. As verbalizações citadas estão identificadas pelas letras $\mathrm{P}$ (pergunta)/ $\mathrm{E}$ (entrevista) seguidas de um número, os quais indicam o número da pergunta na qual a verbalização foi manifestada, bem como o número da entrevista.

São citados dois tipos de incentivos, o primeiro destinado à indústria da reciclagem e o segundo destinado ao próprio gerador de resíduos. As verbalizações listadas a seguir enfatizam os incentivos destinados à indústria:

P1/E5: [...] os governos desoneram muitas indústrias em várias áreas, mas não desonera a parte da reciclagem, que eu acho que seria superinteressante."

P3/E3: [...] sei lá, um ICMS verde pra ajudar indústrias a se instalarem no Estado porque não adianta a gente fazer a coleta seletiva certinha e não ter pra quem vender $[\ldots]$.

P3/E5: [...] se tivessem fontes de recurso que pudessem alimentar essa pequena indústria, você com certeza teria um potencial de reciclagem muito maior e daí desafogaríamos os aterros sanitários [...].

O incentivo às indústrias é um dos instrumentos de políticas para redução da geração de resíduos sólidos urbanos sendo citado inclusive pela PNRS, além disso constam na literatura referencias favoráveis à sua aplicação como em Chermont e Seroa da Motta (1996) e Kinnaman (2016).

É interessante destacar que essas verbalizações foram manifestadas na questão em que os entrevistados deveriam apontar ações prioritárias para implementação dos objetivos da PNRS, o que demostra, de certa forma, não apenas conhecimento a respeito da aplicabilidade dessa categoria de instrumento para as políticas de resíduos, mas também uma percepção positiva a seu respeito.

Como visto no referencial teórico, o subsídio às indústrias é um dos instrumentos de políticas para redução da geração de resíduos sólidos urbanos. É interessante destacar que essas verbalizações foram manifestadas na questão em que os entrevistados deveriam apontar ações prioritárias para implementação dos objetivos da PNRS, o que demostra, de certa forma, não apenas conhecimento a respeito da aplicabilidade dessa categoria de instrumento para as políticas de resíduos, mas também uma percepção positiva a seu respeito.

Nesse ponto, no entanto, é preciso estar atento à real viabilidade econômica da implantação de indústrias de reciclagem, o que não depende apenas de incentivos fiscais. A verbalização destacada a 
seguir ilustra bem a ideia de que bastaria conceder subsídios para que um mercado de reciclagem viesse a se estabelecer:

P10/E4: [...] então se ele tivesse uma isenção do produto, do reciclável, para promover a reciclagem com certeza esse mercado ia migrar e ia abrir vários mercados de reciclagem [...].

A princípio, essa ideia parece simples e tentadora, mas há diversos outros fatores de mercado que precisam ser levados em conta por esse tipo de indústria antes de optar pela abertura de novas plantas. Trata-se, contudo, de um tema que sem dúvida merece maior atenção por parte do governo, pois o grande apelo desse tipo de instrumento transparecer quando são empregadas expressões como "com certeza" e "sem dúvida" nas falas relativas aos incentivos.

O segundo tipo de incentivo observado destina-se aos próprios geradores de resíduos, no sentido de que conceder incentivos é uma forma de levar a mudanças de comportamento, hábito:

P3/E3: [...] a pessoa começa com um pequeno incentivo financeiro e pega o hábito de fazer.

P10/E7: [...] sem dúvidas, descontos em impostos, créditos, ativos verdes, tudo isso vai contribuir significativamente pra uma melhor gestão dos resíduos [...].

Nota-se, porém, que a ideia de incentivo para o cidadão surge como um contraponto à cobrança pela gestão os resíduos, que de fato nem existe ainda no Município de Goiânia. A presença de ressalvas em relação à adoção de uma eventual cobrança contrasta com as manifestações incisivas favoráveis aos incentivos econômicos:

P6/E5: [...] eu acho que é uma obrigação dele, mas acho justo, por exemplo, se ele separa, ele pode diminuir a taxa que ele paga [...].

As ressalvas dizem respeito a um sistema de cobrança homogêneo, no qual o valor cobrado seria igual para todos os geradores sem a possibilidade de abatimento no valor da taxa em função da quantidade de resíduos gerada ou mesmo da adoção de práticas como a separação dos resíduos e a compostagem, por exemplo.

P6/E4: [...] não é justo aí, por exemplo, você instituir uma taxa de coleta de lixo na cidade e aquela pessoa que já faz a coleta seletiva, ele já reduz, ela já recicla, ele já ajuda, já colabora e a coleta às vezes pega menos do que uma pessoa que não faz, ele vai pagar o mesmo tanto?

Dessa forma, seria precipitado concluir que prevalece uma ideia de aceitação da taxa. Pelo contrário, além das ressalvas, devemos ponderar ainda manifestações que imputam um aspecto de punição à taxa, conforme se verifica nas seguintes verbalizações: 
P6/E2: [...] é a questão do poluidor pagador e do poupador recebedor, então eu entendo que mais que punir é dar incentivos.

P8/E5: [...] eu não acho justo não, porque a gente já paga imposto demais e esse dinheiro, se esse dinheiro dos impostos todo que a gente paga fosse destinado aos lugares corretos, a gente não precisava ter mais uma taxa, mas eu não vejo como evitar que ela seja realmente instituída [...].

As ressalvas, somadas à concepção de punição, são um indicativo da existência de certa animosidade em relação à adoção do sistema de cobrança pela gestão de resíduos. De toda sorte, a necessidade de implantação da cobrança pela gestão dos resíduos parece estar bem difundida entre os entrevistados, o que pode ser resultado do contexto recente de discussões a respeito da implantação da taxa dirigida aos grandes geradores de resíduos no município. Mais do que isso, os depoimentos apontam para preferência por uma taxa proporcional à geração de resíduos dos usuários.

Ao citarem um mecanismo de incentivo atrelado à taxa para a gestão dos resíduos, os entrevistados fazem alusão ao sistema de cobrança proporcional à geração dos resíduos. Muitos autores reconhecem a efetividade desse tipo de sistema, porém, ressaltam os altos custos de implementação e operação, bem como o risco de estímulo a destinação irregular, como pontos negativos do sistema proporcional. (KIRAKOZIAN, 2016; KLING; SEYRING; TZANOVA, 2016; PUIG-VENTOSA; SASTRE SANZ, 2017)

Outro tema dentro da categoria dos instrumentos econômicos é o financiamento. Em termos de governo, podemos compreender essa ideia de financiamento como fonte de recursos para área, capacidade de investimentos do setor público, o que pode viabilizar as ações necessárias, a vontade de fazer conforme expresso na verbalização a seguir:

P2/E4: [...] a política precisa realmente estabelecer linhas de financiamento pra poder viabilizar essa vontade de fazer [...].

Por outro lado, o financiamento pode referir-se também à fonte de recursos para instalação de indústrias, o que requer a mesma atenção em relação aos incentivos fiscais, pois a ausência de indústrias de reciclagens pode ser explicada por muitos outros fatores além da ausência de incentivos e fontes de financiamento:

P3/E5: [...]se tivessem fontes de recurso que pudessem alimentar essa pequena indústria, você com certeza teria um potencial de reciclagem muito maior e daí desafogaríamos os aterros sanitários [...].

P2/E8 [...] pra fechar a cadeia produtiva você precisa atrair as empresas de reciclagem [...]. 


\subsubsection{EDUCAÇÃO AMBIENTAL}

Conscientizar a população, no sentido de sensibilizá-la a respeito da importância social e ambiental de destinar os resíduos adequadamente é uma ideia recorrente e surge com bastante vigor quando os entrevistados são questionados a respeito de como a população pode colaborar para a implementação da política, o que está em linha com as ideias expressas em marcos como a PNEA, o PPCS e a IV CNMA.

P3/E3: Educação ambiental de uma maneira geral, campanha em televisão, campanha em rádio, panfletos, envolvimentos em escolas, porque se você educa a criança ela cresce com isso, educação ambiental a partir da base, porque quando você educa a criança, você cria um hábito [...].

P4/E2: A população é a mais importante aí nesse processo [...] o que a gente precisa [...] é dar maior publicidade, maior divulgação, maior informação à sociedade [...], a gente precisa investir mais nessa forma de informação mesmo, informar a população pra que eles saibam que eles são importantes, eles estão com esse papel e eles têm uma obrigação dentro desse processo.

P4/E6: [...] infelizmente a sociedade não tem essa consciência, é uma parcela ínfima da sociedade que faz essa separação em casa [...].

P5/E3: [...] eu acho que o que tá faltando ali um pouco é a questão de educar um pouco a população. A população tem que ser um pouco mais bem-educada [...].

Importante mencionar que há registros na literatura - Schultz (2014), Dai et al. (2016) e Xu et al. (2016) - a respeito da baixa eficácia de ações de educação ambiental pautadas na provisão de informações quando comparadas à provisão de infraestrutura, ou seja, facilitar o descarte dos resíduos de forma adequada pode ser mais eficaz do que conscientizar as pessoas sobre a importância desse ato e de como fazê-lo.

Observaram-se dois âmbitos de intervenção preferencial em termos educação ambiental. O primeiro, aposta na conscientização, pois a população não sabe o quanto a separação dos resíduos é relevante do ponto de vista ambiental. Já o segundo, diz respeito a um conhecimento instrumental, pois a população não sabe como separar os resíduos. As duas verbalizações destacadas a seguir ilustram bem essas duas abordagens:

P1/E5: [...] nós vamos colocar na cabeça das pessoas a necessidade da preservação do meio ambiente [...].

P4/E3: [...] a população tem que se conscientizar primeiro [...], a população tem que aprender a separar [...].

Em apenas uma das entrevistas foi registrada uma percepção destoante das demais, ao considerar que a população local geralmente tem disposição para colaborar: 
P4/E8 [...] eu vejo o seguinte, a população culturalmente ela se mobiliza muito fácil [...].

\subsubsection{QUESTÕES DE GOVERNO}

Essa categoria abriga dois temas ligados a aspectos de governo. O primeiro deles é a descontinuidade das políticas, que se relaciona com outros problemas citados como a falta de vontade política e a falta de recursos. Em um sentido amplo, entende-se que todos esses aspectos são sensíveis a um requisito primário para a construção de capacidade institucional, que é a presença de uma fonte de recursos. Todos esses aspectos surgem nas verbalizações listadas a seguir:

P2/E1: [...] vontade política e orçamento para área [...].

P2/E2: [...] é a questão da descontinuidade política, eu acho que é um dos maiores entraves pra efetivação da política nacional de resíduos sólidos.

P2/E4: [...] técnicos, a gente precisa de pessoal qualificado, não é porque a gente trabalha com lixo que todo mundo acha que entende, tem que ter conhecimento técnico, científico qualificado e competência pra fazer isso [...].

P12/E3: [...] a prefeitura, como todas as prefeituras tá com problemas financeiros $[\ldots]$.

P12/E4: [...] eu acho que tem uma dificuldade, tem muito município que não tem receita, não tem engenheiro, não tem técnico, não tem um gestor [...].

Um segundo tema de destaque dentro das questões de governo é a relevância dos instrumentos de planejamento. Fazer um bom planejamento e colocá-lo em prática são ações sensíveis a problemas como ausência de recursos e descontinuidade política. Outra questão relevante acerca do planejamento é a atualização dos planos de resíduos, especialmente em nível federal, pois serve de guia para os demais entes federados. Cabe lembrar que a versão preliminar do plano nacional de resíduos é de 2011, ou seja, além de nunca ter sido oficialmente aprovada, está bastante defasada.

P5/E4: [...] então precisa de ter planos pra implementar essa política [...].

P3/E8: [...]apesar de já estar previsto os planos de resíduos, eles precisam sair do papel, né, o que tá planejado lá precisa efetivamente ser executado[...].

\subsubsection{LOGÍSTICA REVERSA}

A presença dessa categoria expressa o alcance da noção de logística reversa e do conceito de responsabilidade compartilhada, pois, assim como no caso da educação ambiental, não havia nenhuma pergunta específica afeita a esses temas. 
P1/E2: [...] o termo da política nacional, da responsabilidade compartilhada, eu acho um dos mais importantes, né, porque responsabiliza toda a cadeia, não só a prefeitura, né $[. .$.$] .$

P1/E3: [...] a questão da logística reversa como um todo, que é realmente acionar toda a cadeia, a indústria, o distribuidor e consumidor [...].

P1/E5: [...] então e a discussão mais efetiva acho que tá faltando pra nós, é da logística reversa [...].

P1/E6: [...] eu acho que a logística reversa é o ideal pra gente chegar em uma situação ótima de gestão de resíduos [...].

As verbalizações demonstram grandes expectativas em relação à logística reversa, mesmo diante do atual cenário, no mínimo confuso, em termos de regulamentação desse instrumento instituído pela PNRS. Há ainda diversas lacunas a serem pacificadas a respeito da responsabilidade dos municípios e das empresas em relação ao recolhimento de embalagens, por exemplo.

A primeira fase do acordo setorial de embalagens em geral priorizou a participação das cooperativas de materiais recicláveis na logística reversa e não das prefeituras. Dessa forma o cenário ainda é bastante instável no que concerne à estruturação efetiva de um sistema de logística reversa que se apresente de fato como uma solução para a gestão dos resíduos sólidos urbanos.

Nesse sentido, nota-se claramente a ideia de apoio das empresas à gestão municipal de resíduos como uma opção decorrente do instituto da logística reversa. Porém, dado o atual estágio de desenvolvimento e regulamentação desse instrumento, tal opção deve ser vista com cautela.

P1/E2: [...] o termo da política nacional, da responsabilidade compartilhada, eu acho um dos mais importantes, né, porque responsabiliza toda a cadeia não só a prefeitura, né [...].

P12/E4: [...] acredito que se o município não tiver estrutura, mas tiver vontade, ele pode organizar com a iniciativa privada [...].

Q12/E6: [...] não acho também que sejam eles pra implantar infraestrutura, tem que ser uma coisa de todos, pra isso tem que entrar o comércio, tem que entrar a indústria, pra poder ajudar nessa questão da infraestrutura. Todos aqueles que estão envolvidos na cadeia [...].

\subsubsection{CATADORES DE MATERIAIS RECICLÁVEIS}

Assim como a cobrança pela gestão dos resíduos é vista com ressalva pelos entrevistados, a inclusão dos catadores de materiais recicláveis também é percebida como cautela.

P9/E1: [...] a questão da inclusão dos catadores a gente não pode esconder, é uma realidade [...]. Tem que incluir? Tem que ter uma política de inclusão, do jeito que está sendo feita, não sei se é o ideal [...].

P9/E2: [...] Com certeza, a própria política nacional fala que os resíduos têm que ser encaminhados prioritariamente para as cooperativas [...]. Penso que o 
trabalho que eles fazem de separação dos resíduos é um trabalho muito insalubre, é um trabalho que ele tem que acabar [...], elas só vão conseguir crescer de fato se elas forem contratadas pela prefeitura [...]. O trabalho que eles estão fazendo é de desviar resíduos do aterro sanitário, o trabalho que eles estão fazendo é de limpeza pública, como a SLU, como o sistema de limpeza pública [...].

P9/E3: [...] Sim. Já existe, né? Tem uma lei específica que fala...se o governo deve ajudar? O governo já tá fazendo a parte dele [...], acaba que lá na ponta quem separa o material é eles mesmo, então eu acho que as cooperativas têm que ser mais valorizadas, elas não devem ser encaradas somente como instituições parceiras, não só, elas são mais que isso, elas são prestadoras de serviço para a prefeitura como um todo [...].

P9/E6: [...] a própria política fala que eles têm que ser inseridos, né, eu não acredito que dessa forma, com o tipo de cooperativa que a gente tem hoje, a gente consiga realmente implementar uma logística reversa, porque para ela ser feita tem que virar realmente um negócio [...].

Há uma ideia de obrigação de inserção dos catadores de materiais recicláveis a partir da PNRS. Vale lembrar que a PNRS traz a integração dos catadores como um de seus princípios, não se trata exatamente de uma obrigação, porém, essa compreensão encontra amparo no histórico de apoio do Estado aos catadores de materiais recicláveis, bem como na sua forte atuação política nas últimas décadas.

A necessidade de contratação das cooperativas por parte das prefeituras, bastante citada pelos entrevistados, tem amparo no conceito de coleta seletiva solidária, ideia que vem sendo construída mesmo antes da PNRS com grandes conquistas, a exemplo da possibilidade de dispensa de licitação para a contratação de cooperativas de catadores de materiais recicláveis prevista pela Lei 11.445/2007 e isenção de IPI para materiais oriundos das cooperativas, benefício concedido pela Lei 12.375/2010.

P9/E4: [...] os catadores eles são o elo entre a população e a reciclagem [...] elas prestam um serviço ambiental e esse serviço precisa ser remunerado [...].

P9/E5: [...], mas a parte da prefeitura ela tinha que remunerar esse pessoal, por quê? Por que senão eles ficam como? Eles ficam como simplesmente funcionais ao sistema da questão dos resíduos da cidade, mas nem por isso ganham [...].

A ascensão da logística reversa enseja outro debate acerca da possibilidade de remuneração das cooperativas de catadores de materiais recicláveis não abordado pelos entrevistados, pois o acordo setorial de embalagens teve como ações principais o apoio às cooperativas.

Outro aspecto relevante destacado pelas entrevistas é a percepção do histórico de atuação do governo em prol das cooperativas. Apesar da grande ênfase dada à educação ambiental ao longo da entrevista, quando instados a apontar o tipo de ação que o governo vem priorizando historicamente, os entrevistados não fazem referência a ações de educação ambiental. 
P11/E2: [...] desenvolveu um pouco da parte de infraestrutura [...] teve aí a construção de três novos galpões para as cooperativas [...].

P11/E4: [...] Goiânia tem privilegiado, né, o trabalho com os catadores [...].

P11/E6: [...]eles têm incentivado as cooperativas [...].

Essa percepção pode estar atrelada à própria atuação dos catadores de materiais recicláveis como um movimento social que vem conquistando espaço, influenciando as políticas e assim obtendo apoio. Conquistas como a dispensa de licitação, o apoio das empresas no âmbito do sistema de logística reversa e do Governo Federal para construção de galpões, por exemplo, são visíveis.

\subsubsection{IMPACTOS AMBIENTAIS}

Os resultados indicam o reconhecimento dos impactos negativos associados ao descarte inadequado, bem como da hierarquia para a gestão dos resíduos, as verbalizações em relação aos impactos ambientais foram registradas quando se questiona quais seriam os principais objetivos da PNRS e qual a sua relevância.

A relevância ambiental da PNRS aparece representada na ideia de encerramento dos lixões, com bastante veemência dado emprego de expressões como extinção e erradicar, conforme se verifica nos seguintes trechos:

P1/E2: [...] o principal objetivo da política nacional que eu vejo é a extinção dos lixões.

P1/E3: [...] o principal realmente era erradicar os lixões no país [...].

A noção de hierarquia para a gestão dos resíduos também é manifestada, o que indica que está sendo incorporada. Muito embora a hierarquia imponha a redução da geração de resíduos e da disposição em aterros, conforme o conceito abraçado pela PNRS.

P1/E4: [...] promover a gestão integrada dos resíduos dentro de uma hierarquia de prioridades [...].

P1/E8: [...] Prevenir resíduos, né [...] não tem a hierarquização de resíduos do art. 9 ? Tem que seguir aquilo lá, aquilo ali não é uma pretensão ou programa é uma obrigação [...].

\section{CONCLUSÃO}

Há uma variedade de instrumentos que podem ser empregados pelas políticas de gestão de resíduos, desde regulamentos de comando e controle até os instrumentos sociopsicológicos, passando ainda por aqueles de natureza econômica, que representam a maior parte dos instrumentos mencionados por esse trabalho. 
Os resultados indicam uma preferência pelo uso da educação ambiental como um instrumento de política pública no que tange à implementação da PNRS. Essa preferência remonta a uma construção social que tem origem em ideias que permeiam todos os grandes marcos do Governo Federal envolvendo essa política até o ano de 2013.

O diagnóstico de falta de consciência da população como um dos maiores entraves para a implementação da política de resíduo compõe uma visão, um referencial, a respeito da PNRS que vem sendo construído há pelo menos duas décadas. Fundamenta-se nesse referencial a inclinação à adoção de medidas de educação ambiental - a solução para a pretensa falta de consciência da população observada no plano de resíduos do Município de Goiânia.

Ao analisar as entrevistas verificou-se um alinhamento entre as visões expressas pelos entrevistados e o referencial identificado no decorrer do trabalho. Demonstrada a existência de um referencial, bem como evidenciado o seu impacto no âmbito local, torna-se clara a configuração de um ambiente propício à ocorrência da heurística da representatividade nos termos descritos por Kahneman (2012).

A heurística da representatividade pode afetar o processo de escolha dos instrumentos para a implementação das políticas de resíduos sólidos urbanos, uma vez que leva à supervalorização da evidência aparentemente mais coerente. Neste caso, o diagnóstico de falta de consciência da população, bem como a preferência pela educação ambiental como meio de contornar esse problema, são as evidências supervalorizadas em função da influência do referencial da PNRS identificado neste trabalho.

Assim, no momento da escolha dos instrumentos, estando ausentes critérios objetivos de seleção, a educação ambiental seria supervalorizada diante de outras opções, tais como os instrumentos econômicos, as quais seriam fatalmente desconsideradas, pois não há um referencial que confira coerência a escolha desses instrumentos, tal como ocorre com a educação ambiental. A ocorrência desse efeito, explica então a preferência pela implementação de iniciativas de educação ambiental no âmbito do plano de resíduos do município de Goiânia.

Desse modo, caso o Governo Federal opte por fomentar o uso de outra categoria de instrumentos, tais como os de natureza econômica, recomenda-se a formação de um novo referencial, delineado em documentos oficiais como o plano nacional de resíduos sólidos e demais estratégias de governo relacionadas à gestão de resíduos. É aconselhável, ainda a promoção de seminários e eventos de divulgação, bem como a oferta de capacitações direcionadas aos técnicos municipais a respeito da aplicação de instrumentos econômicos no âmbito das políticas para gestão de resíduos. 
Nesse mesmo sentido, recomenda-se a elaboração de estudos de abrangência nacional e estadual sobre a viabilidade de implantação de indústrias de reciclagem, no intuito de subsidiar a tomada de decisão a respeito da concessão ou não de incentivos e subsídios para a cadeia da reciclagem.

É indispensável a constante atualização do plano nacional de resíduos sólidos, instrumento referência para os demais entes federados. Além de atualizado, o plano poderia oferecer uma relação de instrumentos de políticas para redução da geração dos resíduos sólidos urbanos, com seus prós e contras, bem como critérios e metodologias de escolha para esses instrumentos. Dessa maneira, o plano nacional ofereceria subsídios para que os instrumentos no âmbito local não sejam escolhidos sem o emprego de critérios técnicos, podendo, assim, adequar-se melhor a cada perfil municipal.

É possível ainda fomentar o uso de instrumentos econômicos, concedendo incentivos aos municípios que os adotarem. O Governo Federal pode, por exemplo, facilitar o acesso a fontes de financiamento para aqueles municípios que implantarem sistemas de cobrança pela gestão dos resíduos. É importante, nestes casos, que sejam instituídos diferente mecanismos de incentivo, a fim de atender a diferentes perfis municipais. Assim, municípios que já efetuam a cobrança pela gestão dos resíduos, poderiam receber incentivos para implantar à coleta seletiva, ou regularizar o aterro sanitário, por exemplo.

Em relação aos catadores de materiais recicláveis, merece destaque a ideia de que o apelo social intricado ao tema pode funcionar como um fator motivacional para que a população descarte os resíduos de forma adequada, pois ao descartar os resíduos corretamente, contribui-se para a melhoria de vida de um segmento social. Isto posto, recomenda-se integrar os catadores de materiais recicláveis a eventuais mecanismos de incentivo ao cidadão no intuito de incrementar o potencial de motivação destes instrumentos.

As ressalvas à implantação de um sistema de cobrança pela gestão expressam uma ambiguidade, pois ao mesmo tempo em que se reconhece a imprescindibilidade desse instrumento, associa-se a sua efetivação à uma ideia de punição ao gerador de resíduos. Uma maneira de contornar essa visão é promover um sistema de cobrança atrelado a mecanismos de incentivo econômico, concedendo descontos ou outros benefícios para os geradores que adotarem determinadas condutas, tais como a separação dos resíduos recicláveis e a compostagem. O plano nacional de resíduos sólidos parece ser o instrumento mais adequado para fornecer diretrizes para adoção de mecanismos com essas características. 
Outra questão relevante reside no destaque inesperado conferido à logística reversa. Tal destaque é preocupante na medida em que revela uma grande expectativa na implementação do sistema de logística reversa de embalagens em geral, visto como um auxiliar dos sistemas municipais de gestão de resíduos.

Porém, apesar de avanços, como a assinatura do acordo setorial de embalagens em geral no ano de 2016, a implementação da logística reversa segue intrincada em termos de regulamentação, dependente de morosas negociações em torno dos acordos setoriais, motivo pelo qual não se vislumbra que este tipo de instrumento possa ser considerado uma solução efetiva para a gestão de resíduos no curto prazo.

Cabe ao Governo Federal prestar informações atualizadas e confiáveis a respeito do estágio de implementação da logística reversa de embalagens em geral, das dificuldades enfrentadas e das reais oportunidades proporcionadas até o momento, para que, assim, os municípios possam avaliar se devem, ou não, envidar esforços na adoção de políticas e instrumentos atrelados à logística reversa. 


\section{REFERÊNCIAS}

ALMEIDA, L. T. DE. Política Ambiental: uma análise econômica. 1. ed. São Paulo: Fundação Editora da Unesp, 1998.

BALESTRIN, A. Uma análise da contribuição de Herbert Simon para as teorias organizacionais. Revista Eletrônica de Administração, v. 8, n. 4, p. 17, 2013.

BARROS, D. A. et al. Breve análise dos instrumentos da política de gestão ambiental brasileira. Política \& Sociedade, v. 11, n. 22, p. 155-179, 2012.

BARTL, A. Moving from recycling to waste prevention: A review of barriers and enables. Waste Management \& Research, v. 32, n. 9_suppl, p. 3-18, 2014.

BAUMOL, W. J.; OATES, W. E. The theory of environmental policy. Cambridge: Cambridge University Press, 1988.

BERNARDO, C. T. S.; NOGUEIRA, J. M. The 15 years of SNUC: An analysis in the light of environmental economics | Os 15 anos de SNUC: Uma análise à luz da economia ambiental. Espacios, v. 37, n. 21, 2016.

BERSCH, K.; PRAÇA, S.; TAYLOR, M. M. State Capacity, Bureaucratic Politicization, and Corruption in the Brazilian State. Governance, v. 30, n. 1, p. 105-124, 2017.

BÖCHER, M. A theoretical framework for explaining the choice of instruments in environmental policy. Forest Policy and Economics, v. 16, p. 14-22, 1 mar. 2012.

BRASIL. MINISTÉRIO DAS CIDADES - SECRETARIA NACIONAL DE SANEAMENTO AMBIENTAL. Diagnóstico do Manejo de Resíduos Sólidos Urbanos - 2016. Brasilia: MCIDADES - SNSA, 2018.

BRASIL. Lei n. 9.795, de 27 de abril de 1999. Dispõe sobre a educação ambiental, institui a Política Nacional de Educação Ambiental e dá outras providências., 1999.

BRASIL. Decreto de 11 de setembro de 2003. Cria o Comitê Interministerial da Inclusão Social de Catadores de Lixo., 2003.

BRASIL. Lei n. 12.305, de 02 de ago. 2010. Política Nacional de Resíduos Sólidos, 2010a.

BRASIL. Decreto n. 7.404, de 23 de dezembro de 2010. Regulamenta a Lei no 12.305, de 2 de agosto de 2010, 2010b.

BRASIL. Presidente (2003-2011) Luiz Inácio Lula da Silva. Discurso durante cerimônia de sanção do Projeto de Lei que cria a Política Nacional de Resíduos Sólidos, 2010c.

BRASIL. Decreto n. 7.405, de 23 de dezembro de 2010. Institui o Programa Pró-Catador., 2010d.

BRASIL. PLANO DE AÇÃO PARA PRODUÇÃO E CONSUMO SUSTENTÁVEIS - PPCS. Brasília: [s.n.]. 
BRASIL. 4O CONFERÊNCIA NACIONAL DO MEIO AMBIENTE: TEXTO ORIENTADOR. Brasília: [s.n.]. Disponível em: <http://www.ipea.gov.br/participacao/images/pdfs/conferencias/4CNMA/textoorientador.pdf>.

BRASIL. Programa Lixão zero. Brasília: [s.n.]. Disponível em:

<https://www.mma.gov.br/images/agenda_ambiental/residuos/planodeacao.pdf>.

CÂMARA, R. H. Análise de Conteúdo: da teoria à prática em pesquisas sociais aplicadas às Organizações. Gerais: Revista Interinstitucional de Psicologia, v. 6, n. (2), p. 179-191, 2013.

CAPELLA, A. C. Formulação de Políticas Públicas. p. 153, 2018.

CHERMONT, L. S.; SEROA DA MOTTA, R. Aspectos Econômicos da Gestão Integrada de Resíduos SólidosRio de Janeiro, 1996.

CONN, W. D. Waste reduction. Issues and policies. Resources Policy, v. 3, n. 1, p. 23-38, mar. 1977.

CORVELLEC, H. A performative definition of waste prevention. Waste Management, v. 52, p. 3-13, 2016.

COX, J. et al. Household waste prevention - A review of evidence. Waste Management and Research, v. 28, n. 3, p. 193-219, 2010.

DAI, Y. C. et al. Information strategy failure: personal interaction success, in urban residential food waste segregation. Journal of Cleaner Production, v. 134, n. Part A, p. 298-309, 2016.

DEMAJOROVIC, J. Da política tradicional de tratamento do lixo à política de gestão de resíduos sólidos. Revista de Administraçaõ de Empresas / EAESP/FGV, v. 35, n. 3, p. 88-93, 1995.

FGV PROJETOS. Política Nacional e Gestão Municipal de Resíduos Sólidos. Rio de Janeiro: FGV, 2015.

GENTIL, E. C.; GALLO, D.; CHRISTENSEN, T. H. Environmental evaluation of municipal waste prevention. Waste Management, v. 31, n. 12, p. 2371-2379, 2011.

GODECKE, M. V. et al. O Consumismo E a Geração De Resíduos Sólidos Urbanos No Brasil. Rev. Elet. em Gestão, Educação e Tecnologia Ambiental, v. 8, n. 8, p. 1700-1712, 2012.

GOIÂNIA. Lei n. 9.498, de 19 de novembro de 2014. Dispõe sobre a cobrança de preço público decorrente da prestação de serviços de coleta, transporte e destinação final de resíduos sólidos produzidos por grandes geradores e dá outras providências., 2014.

GOIÂNIA. Plano municipal de gestão integrada de resíduos sólidos de Goiânia. Goiânia: [s.n.]. Disponível em:

<https://www10.goiania.go.gov.br/dadosinter/sisrs/documentos/planogestaoresiduossolidos.pdf>.

GOIÂNIA. Decreto n. 728, de 14 de março de 2016. Regulamenta a Lei no 9.498, de 19 de novembro de 2014, 2016b.

GOIÁS. Lei n. 14.248, de 29 de julho de 2002. Política Estadual de Resíduos Sólidos, 2002. 
GOULDER, L. H.; PARRY, I. W. H. Instrument choice in environmental policy. Review of Environmental Economics and Policy, v. 2, n. 2, p. 152-174, 2008.

GOUVEIA, N. Resíduos sólidos urbanos: impactos socioambientais e perspectiva de manejo sustentável com inclusão social. Ciência \& Saúde Coletiva, v. 17, n. 6, p. 1503-1510, 2012.

GUNNINGHAM, N. Environment law, regulation and governance: Shifting architectures. Journal of Environmental Law, v. 21, n. 2, p. 179-212, 2009.

HARJULA, H. OECD workshop on waste prevention: toward performance indicators, 2002.

HEBER, F.; SILVA, E. M. DA. Institucionalização da Política Nacional de Resíduos Sólidos: dilemas e constrangimentos na Região Metropolitana de Aracaju (SE). Revista de Administração Pública, v. 48, n. 4, p. 913-937, 2014.

HOWLETT, M.; RAMESH, M.; PERL, A. Política Pública: seus ciclos e subsistemas: uma abordagem integrada. 3. ed. Rio de Janeiro: Elsevier Ltd, 2013.

IPEA - INSTITUTO DE PESQUISA ECONÔMICA APLICADA. Pesquisa sobre Pagamento por Serviços Ambientais Urbanos para Gestão de Resíduos Sólidos. p. 66, 2010.

KAHNEMAN, D. Rápido e Devagar: duas formas de pensar. 1. ed. Rio de Janeiro: Objetiva, 2012.

KINNAMAN, T. C. Optimal solid waste tax policy with centralized recycling. National Tax Journal, v. 63, n. June, p. 237-252, 2010.

KINNAMAN, T. C. Understanding the Economics of Waste: Drivers, Policies, and External Costs. International Review of Environmental and Resource Economics, v. /8, n. 3-4, p. 281-320, 2016.

KINNAMAN, T.; FULLTERTON, D. The Economics of Residential Solid Waste ManagementCambridge, MA, ago. 1999. Disponível em:

<https://pdfs.semanticscholar.org/53a3/18a2a29a5021e5cd9df30235dac8f4fef2b8.pdf>. Acesso em: 6 abr. 2018

KIRAKOZIAN, A. One Without the Other? Behavioural and Incentive Policies for Household Waste Management. Journal of Economic Surveys, v. 30, n. 3, p. 526-551, 2016.

KLING, M.; SEYRING, N.; TZANOVA, P. Assessment of economic instruments for countries with low municipal waste management performance: An approach based on the analytic hierarchy process. Waste Management \& Research, v. 34, n. 9, p. 912-922, 1 set. 2016.

KRUTILLA, K. Transaction Costs and Environmental Policy: An Assessment Framework and Literature Review. International Review of Environmental and Resource Economics, v. 4, n. 3-4, p. 261-354, 2011.

LIMA, L. L.; D’ASCENZI, L. Implementação de políticas públicas: perspectivas analíticas. Revista de Sociologia e Política, v. 21, n. 48, p. 101-110, 2013.

LINDER, S. H.; PETERS, B. G. Instruments of Government: Perceptions and Contexts. Journal of Public Policy, v. 9, n. 01, p. 35, 28 jan. 1989. 
LUDWIG, C.; HELLWEG, S.; STUCKI, S. Municipal Solid Waste Management. Berlin, Heidelberg: Springer Berlin Heidelberg, 2003.

MACHADO, P. A. L. Princípios da política nacional de resíduos sólidos Artigos. Revista do Tribunal Regional Federal da 1a Região, v. 24, n. 7, p. 25 a 33, 2012.

MAGALHÃES, A. M. Governança ambiental no Brasil : instituições, atores e políticas públicas. Brasília: IPEA, 2016.

MAIELLO, A.; BRITTO, A. L. N. DE P.; VALLE, T. F. Implementação da Política Nacional de Resíduos Sólidos. Revista de Administração Pública, v. 52, n. 1, p. 24-51, jan. 2018.

MONTEIRO, J. H. P. et al. Manual Gerenciamento Integrado de Resíduos Sólidos. Rio de Janeiro: Secretaria Especial de Desenvolvimento Urbano da Presidência da República - SEDU/PR, 2001.

MUELLER, C. C. Economia e meio ambiente na perspectiva do mundo industrializado: uma avaliação da economia ambiental neoclássica. Estudos Econômicos (São Paulo), v. 26, p. 261-304, 1996.

MULLER, P. As Políticas Públicas. Niterói: Eduff, 2018.

NOGUEIRA, J. M.; PEREIRA, R. Critérios e análise econômicos na escolha de políticas ambientaisBrasília, 2000. Disponível em:

<http://www.ceemaunb.com/jmn/publicacoes/04CriterioseAnalise.pdf >

OLIVEIRA, T. B. DE; GALVÃO JUNIOR, A. DE C. Planejamento municipal na gestão dos resíduos sólidos urbanos e na organização da coleta seletiva. Engenharia Sanitaria e Ambiental, v. 21, n. 1, p. 55-64, 2016.

PALMER, K.; SIGMAN, H.; WALLS, M. The cost of reducing municipal solid waste. Journal of Environmental Economics and Management, v. 33, n. 2, p. 128-150, 1997.

PEREIRA, M. C. G.; TEIXEIRA, M. A. C. A inclusão de catadores em programas de coleta seletiva: da agenda local à nacional The inclusion of collectors in selective recyclable waste programs: from the local to the national agenda. Cad. EBAPE.BR FGV, v. 9, 2011.

PHILLIPS, P. S. et al. Corby Waste Not: An appraisal of the UK's largest holistic waste minimisation projectResources, Conservation and Recycling, 2002. Disponível em:

<www.elsevier.com/locate/resconrec>. Acesso em: 8 maio. 2018

PUIG-VENTOSA, I.; SASTRE SANZ, S. An exploration into municipal waste charges for environmental management at local level: The case of Spain. Waste Management \& Research, 2017.

SALHOFER, S. et al. Potentials for the prevention of municipal solid waste. Waste Management, v. 28, n. 2, p. 245-259, 2008.

SANDEL, M. J. Justiça - O que é fazer a coisa certa. 26. ed. Rio de Janeiro: Civilização Brasileira, 2019.

SBICCA, A. Heurísticas no estudo das decisões econômicas: contribuições de Herbert Simon, Daniel Kahneman e Amos Tversky. Estudos Econômicos (São Paulo), v. 44, n. 3, p. 579-603, set. 2014. 
SCHMALENSEE, R.; STAVINS, R. N. The design of environmental markets: What have we learned from experience with cap and trade? Oxford Review of Economic Policy, v. 33, n. 4, p. 572-588, 2017.

SCHULTZ, P. W. Strategies for promoting proenvironmental behavior: Lots of tools but few instructions. European Psychologist, v. 19, n. 2, p. 107-117, 2014.

SEROA DA MOTTA, R. Analyzing the environmental performance of the Brazilian industrial sector. Ecological Economics, v. 57, n. 2, p. 269-281, 2006.

SERÔA DA MOTTA, R.; HUBER, R. M.; RUITENBEEK, H. J. Policy Options Market based instruments for environmental policymaking in Latin America and the Caribbean : lessons from eleven countries. Environment, v. 4, p. 177-201, 1999.

SEROA DA MOTTA, R.; SAYAGO, D. E. Propostas de Instrumentos Econômicos Ambientais para a Redução do Lixo Urbano e o Reaproveitamento de Sucatas no Brasil. Texto para Discussão - IPEA, p. $58,1998$.

SIQUEIRA, T. M. O. DE; ASSAD, M. L. R. C. L. COMPOSTAGEM DE RESÍDUOS SÓLIDOS URBANOS NO ESTADO DE SÃO PAULO (BRASIL). Ambiente \& Sociedade, v. 18, n. 4, p. 243-264, dez. 2015.

SOUZA, C. Políticas Públicas: uma revisão da literatura. Political Science, v. 8, n. 2003, p. 20-45, 2006.

STAVINS, R. N. The problem of the commons: Still unsettled after 100 years. American Economic Review, v. 101, n. 1, p. 81-108, 2011.

STERNER, T.; CORIA, J. Policy Instruments for Environmental and Natural Resource Management. 2. ed. New York: RFF Press, 2012.

TAYLOR, D. C. Policy incentives to minimize generation of municipal solid waste. Waste Management and Research, v. 18, n. 5, p. 406-419, out. 2000.

ULLRICH, D. R.; OLIVEIRA, J. S. DE; BASSO, K. Reflexões teóricas sobre confiabilidade e validade em pesquisas qualitativas : em direção à reflexividade analítica. Revista de Administração da PUCRS, p. 19-30, 2012.

VAN EWIJK, S.; STEGEMANN, J. A. Limitations of the waste hierarchy for achieving absolute reductions in material throughput. Journal of Cleaner Production, 2016.

WILSON, D. C. et al. "Wasteaware" benchmark indicators for integrated sustainable waste management in cities. Waste Management, v. 35, p. 329-342, 2015.

WILSON, D. C.; VELIS, C. A. Waste management - still a global challenge in the 21st century: An evidence-based call for action. [s.l: s.n.]. v. 33

WORLD BANK. Five Years after Rio: Innovations in Environmental Policy.Environmentally Sustainable Development Studies and Monograph Series, no. 18. Washington, DC: World BankWashington, DC, 1997.

XU, D. Y. et al. Perceived key elements of a successful residential food waste sorting program in urban apartments: stakeholder views. Journal of Cleaner Production, v. 134, n. Part A, p. 362-370, 2016. 
ZACHO, K. O.; MOSGAARD, M. A. Understanding the role of waste prevention in local waste management: A literature reviewWaste Management and Research, 2016.

ZELLER, K. Instrumentos econômicos na Política Ambiental Urbana: desafios na área de resíduos sólidos. In: Cadernos Adenauer XV, n. 2, p. 55-68, 2014.

ZORPAS, A. A.; LASARIDI, K. Measuring waste prevention. Waste Management, v. 33, n. 5, p. 10471056, 2013. 


\section{NOTAS}

\section{Nota 1}

Art. 9 da PNRS - na gestão e gerenciamento de resíduos sólidos, deve ser observada a seguinte ordem de prioridade: não geração, redução, reutilização, reciclagem, tratamento dos resíduos sólidos e disposição final ambientalmente adequada dos rejeitos.

\section{Nota 2}

Uma maneira de evitar eventuais conflitos talvez seja a separação entre as atividades de operação e planejamento e gestão do sistema de manejo de resíduos.

\section{Nota 3}

Conforme redação dada pela Lei 13097/2015: “Os estabelecimentos industriais farão jus, até 31 de dezembro de 2018, a crédito presumido do Imposto sobre Produtos Industrializados - IPI na aquisição de resíduos sólidos utilizados como matérias-primas ou produtos intermediários na fabricação de seus produtos".

\section{Nota 4}

Resíduos Sólidos Domésticos.

\section{Nota 5}

Entre o final da década de 1990 e os anos 2000, os catadores se articularam com apoio de organizações da sociedade civil, o que culminou na fundação do Movimento Nacional dos Catadores de Materiais Recicláveis (MNCR), em 2001. (PEREIRA; TEIXEIRA, 2011).

\section{Nota 6}

https://www.mma.gov.br/responsabilidade-socioambiental/producao-e-consumosustentavel/plano-nacional.html

\section{Nota 7}

Disponível em:

http://www.ipea.gov.br/participacao/images/pdfs/conferencias/4CNMA/texto-orientador.pdf Nota 8

Entendida aqui, genericamente, como coleta seletiva com participação de catadores de materiais recicláveis.

\section{Nota 9}

Minuta anexa ao processo 2018/0000299. Disponível em: http://www.goiania.go.leg.br/processolegislativo/consulta-de-processos.

\section{Nota 10}

Disponível em: http://www.mma.gov.br/images/agenda_ambiental/residuos/planodeacao.pdf

Nota 11

Disponível em: https://www25.senado.leg.br/web/atividade/materias/-/materia/137118 